\title{
Chapter 5 \\ Phyllospheric Microbiomes: Diversity, Ecological Significance, and Biotechnological Applications
}

\author{
Natesan Sivakumar, Ramamoorthy Sathishkumar, Gopal Selvakumar, \\ Rajaram Shyamkumar and Kalimuthu Arjunekumar
}

\begin{abstract}
The phyllosphere referred to the total aerial plant surfaces (above-ground portions), as habitat for microorganisms. Microorganisms establish compositionally complex communities on the leaf surface. The microbiome of phyllosphere is rich in diversity of bacteria, fungi, actinomycetes, cyanobacteria, and viruses. The diversity, dispersal, and community development on the leaf surface are based on the physiochemistry, environment, and also the immunity of the host plant. A colonization process is an important event where both the microbe and the host plant have been benefited. Microbes commonly established either epiphytic or endophytic mode of life cycle on phyllosphere environment, which helps the host plant and functional communication with the surrounding environment. To the scientific advancement, several molecular techniques like metagenomics and metaproteomics have been used to study and understand the physiology and functional relationship of microbes to the host and its environment. Based on the available information, this chapter describes the basic understanding of microbiome in leaf structure and physiology, microbial interactions, especially bacteria, fungi, and actinomycetes, and their adaptation in the phyllosphere environment. Further, the detailed information related to the importance of the microbiome in phyllosphere to the host plant and their environment has been analyzed. Besides, biopotentials of the phyllosphere microbiome have been reviewed.
\end{abstract}

Keywords Biotechnological applications • Diversity $\cdot$ Ecological significance • Phyllospheric microbiomes $\cdot$ Plant growth promotion

\footnotetext{
N. Sivakumar $(\bowtie) \cdot$ R. Sathishkumar $\cdot$ K. Arjunekumar Department of Molecular Microbiology, School of Biotechnology, Madurai Kamaraj University, Madurai 625 021, Tamilnadu, India

e-mail: microshivaak@gmail.com

G. Selvakumar

Department of Microbiology, Allagappa University, Karaikudi-03, Tamilnadu, India

R. Shyamkumar

Department of Biotechnology, Kamaraj College of Engineering and Technology, Vellakovil, Kallikudi, Madurai, Tamilnadu, India
} 


\subsection{Introduction}

The term phyllosphere is referred to as "the aerial part of the plant or the parts of a plant above the ground usually surface of leaves, considered as a habitat for microorganisms." This is a place where normally a variety of microorganism (bacteria, yeasts, and fungi) colonizes. The global leaf area corresponds to both upper and lower surfaces, has approximately twice as great as the land surface area (Vorholt 2012). The phyllosphere is the ambient region for microbes to colonize and establish its association with plants usually epiphytes. Microbial communities in the phyllosphere are highly complex and consist of many cultured and uncultured microorganisms (Müller and Ruppel 2014). It has a heterogeneous group of the microbial association at the micrometer scale area due to its diverse microenvironments (habitats). The phyllospheric microbes are adapted to the insensitive environmental conditions, specifically microbial epiphytes are highly exposed to atmospheric temperature, light, UV radiation, less water, and nutrient availability. These external factors affect the composition and diversity of phyllospheric microbial communities (Vorholt 2012). However, the type of plant and invading microbial populations (pathogens) are also influencing the commensals and/or mutualistic relationship with their host plant (Lindow and Brandl 2003). Less number of studies are available for the microbiology of phyllosphere rather than plant root. Moreover, with increasing anthropogenic stresses, the diversity and community structure of phyllosphere microflora have been continually modified. In this chapter, we focused on the phyllospheric microbiome, structure and diversity, epiphytic mechanism, molecular interactions, ecological significance, and the microbial importance in biotechnology.

\subsection{Basic Understanding of Leaf Structure}

The leaf is a highly organized and multi-layered plant organ (Fig. 5.1), which consists of the epidermis (upper and lower) covered by a waxy cuticle that provides a physical barrier against abiotic and biotic stresses. The epidermis involves many regulatory processes of leaf physiology including gas exchange, temperature regulation, primary production, secretion of secondary metabolites, and water mobilization. Also, a specialized epidermal cell such as stomata, hydathodes (modified stomata), and trichomes (outgrowth) are there in the epidermis. The stomata are surrounded by two cupped hand cells called guard cells, which may open or close due to internal water pressure. Inside the leaf, a layer of cells called the mesophyll, is present, usually two layers, namely, palisade layer and the spongy layer. They contain chlorophyll and photosynthesis occurs in these cells. The palisade cells are more column cells and the spongy cells are more loosely packed between the palisade layer and the lower epidermis, and it allows for gas exchange. The veins of the leaf contain the vascular tissue, xylem and phloem are found in it. Veins run from tips of the roots and are extended up to the edges of the leaves. The outer layer cells are called bundle sheath 


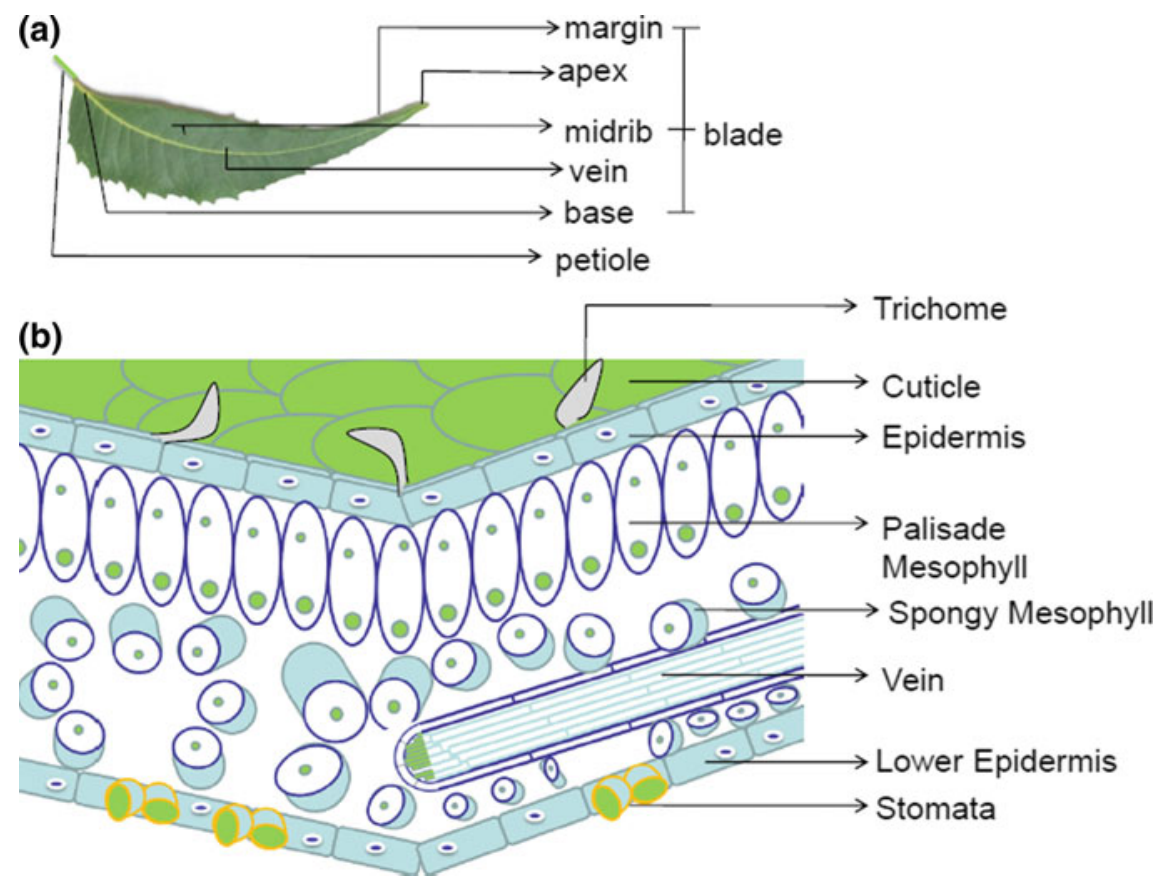

Fig. 5.1 Structural organization of a leaf

cells which circle the xylem and the phloem. The xylem transports water and phloem transports sugar (food).

Glandular trichome of the epidermis releases a wide spectrum of leaf exudates, such as polysaccharide salts, lipids, volatile compounds, and proteins, and its function is associated with plant-microbe and plant-insect interactions (Hirano and Upper 1983). But, non-glandular trichome involves regulation of water tension, light absorption, and protect the leaf from UV radiation and heat as well as drought tolerance (Hirano and Upper 1983).

\subsection{Phyllosphere Habitat}

The phyllosphere is a unique and dynamic habitat which constitutes irregular, and sometimes relatively large microbial community inhabitant in the ecosystem (Whipps et al. 2008). The total terrestrial phyllosphere area estimated is around $6.4 \times 10^{8} \mathrm{~km}^{2}$ (Morris and Kinkel 2002), and it exhibits numerous microhabitat which represents a major source of microorganism. Variety of bacteria, filamentous fungi, and yeasts are naturally colonized on the phyllosphere region and less frequently, protozoa and 
nematodes. These microorganisms exhibit commensalism and/or mutualism (symbionts) or antagonism type of relationship on their host plants. The microbial association in phyllosphere has several advantages and importance to global processes including biogeochemical cycles (carbon and nitrogen) and environmental impact.

\subsubsection{Microbial Assembly on Leaf}

The arrangement of leaf epidermal cells describes the leaf physiology and the microenvironment which allow the abundance and distributions of microorganisms on the leaf surface (Shiraishi et al. 2015; Esser et al. 2015). Simply, epiphytes make biofilm-like growth, most preferably larger bacterial aggregates are on the trichomes, veins, and epidermal cell groves (Brewer et al. 1991; Morris et al. 1997), where the leaf exudates containing nutrient-rich region. The presence of outer cuticle and its physiology help the microbes to colonize this site. Presence of aliphatic compounds in the cuticle layer determines the physicochemical properties of the leaf surface and renders the permeability and wettability, which facilitate the adherence of microorganisms (Sadler et al. 2016). Water permeability of this site may play a vital role in the survival and growth of the epiphytes. Moreover, leaching the nutrients along with water makes the epiphytes to utilize and develop colonies on the phyllosphere (Burch et al. 2014). The leaf surface with higher water and nutrient penetration is heavily colonized by bacterial communities (Beattie 2011). In general, bacteria maintain the cuticular permeability by secretion of biosurfactants, for example, Pseudomonas syringae release syringafactin on the cuticle layer of the leaf which facilitate the availability of sugar for persistent epiphytic growth (Van der Wal and Leveau 2011). Similarly, fructose availability by Pantoea eucalypti 299R and Pantoea agglomerans (Leveau and Lindow 2001). Figure 5.2 represents the phyllosphere microbial assemblage, wherein the epiphytic microorganism exploits this microenvironment for special distribution of microbes, survival as well as blooming (colonization). At the same time, surface microorganisms change the phyllosphere chemistry, and they render the heterogeneous oligotrophic mode of epiphytic life. Besides, microorganism establishes special niches on the leaf surface with the interactive mode of life (Agler et al. 2016) in this microhabitat microbial population can be constantly maintained.

\subsection{Microbial Diversity in the Phyllosphere}

The phyllosphere consists of diverse numerous microbial communities including bacteria, filamentous fungi, yeasts, algae, and protozoans (Whipps et al. 2008; Verma et al. 2013, 2015, 2016a, b). The nature of various microorganisms (epiphytic and endophytic) associated with phyllosphere is given in Fig. 5.3. Among the diverse community of microbes, bacteria are the predominant community on leaves and its 


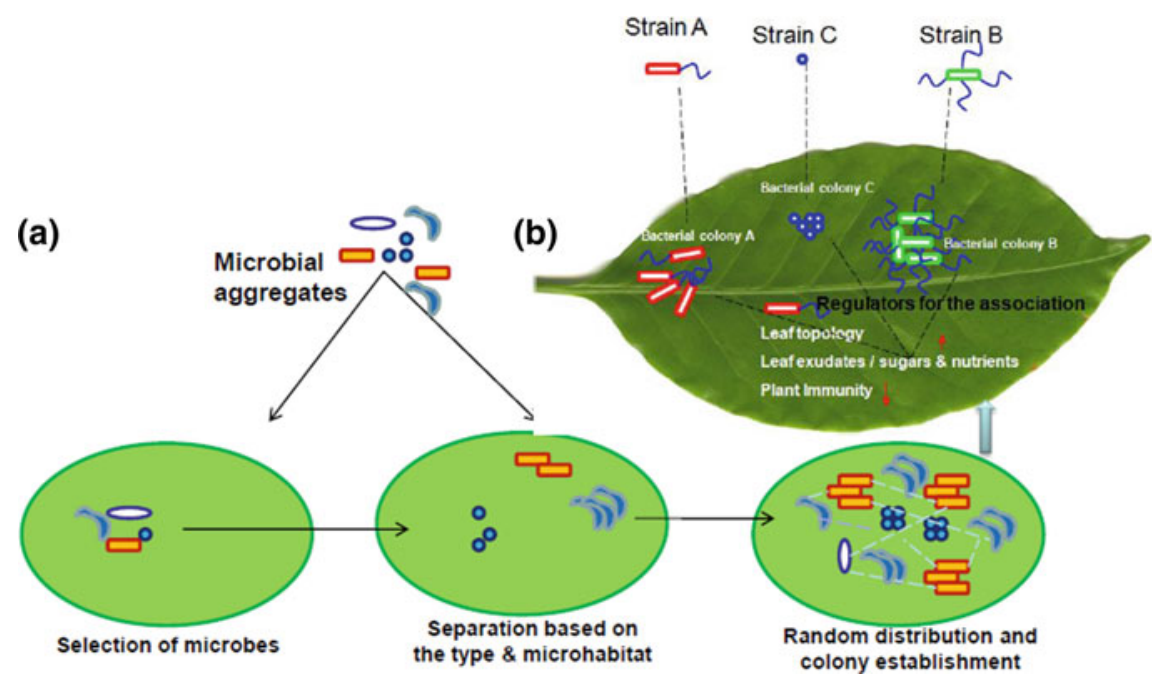

Fig. 5.2 Structure of phyllosphere microbial assemblage. a stages for microbial community structure development, b regulations for the microbial community structure in phyllosphere

Fig. 5.3 Epiphytic and endophytic microbes in phyllosphere

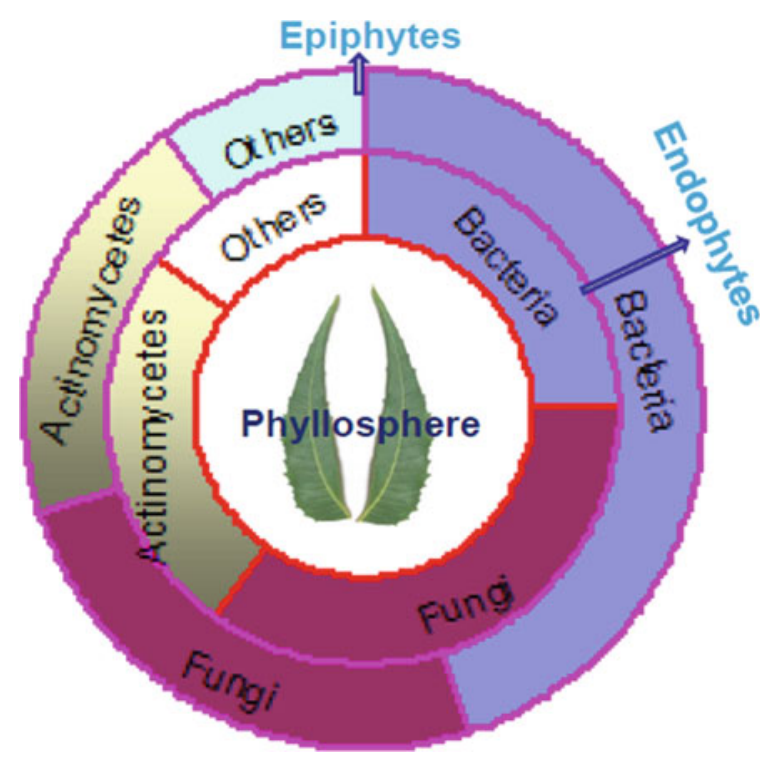

range is between $10^{2}$ and $10^{12} \mathrm{~g}^{-1}$ of the leaf (Inacio et al. 2002). The conventional culture-based method has been used for the identification of different microbial communities of the leaves. Thompson et al. (1993) identified 78 bacterial species from the sugar beet, and Legard et al. (1994) screened 88 bacterial species from 37 genera. 
However, the culture-dependent method based profiling of phyllosphere communities is likely to be incorrect and miscalculates diversity (Rasche et al. 2006). The culture-independent approaches like 16S rDNA sequences of the whole microbial mass of phyllosphere could give the complete and complex microbial community structure of the environment. Molecular studies suggested that alpha-, beta- and gammaproteobacteria and firmicutes are the dominant bacterial inhabitants of the phyllosphere. Frequently, acidobacteria, actinobacteria, and cyanobacteria are also occurring in the phyllosphere environment (Kadivar and Stapleton 2006). Lambais et al. (2006) identified that $97 \%$ of the bacterial sequences of the phyllosphere have been new and unidentified. Yang et al. (2001) reported large numbers of novel bacteria from the phyllosphere of crop plants. The number of studies confirmed the diversity of yeast in the phyllosphere environment as an epiphyte.

The cultivable yeasts genera such as Cryptococcus, Sporobolomyces, and Rhodotorula and its species have been largely inhabitant in the plant leaf (Thompson et al. 1993; Glushakova and Chernov 2004). Moreover, the culture-dependent methods have been used to study the abundance of filamentous fungi, ranging from $10^{2}$ to $10^{8} \mathrm{CFU} \mathrm{g}^{-1}$. Genera such as Cladosporium, Alternaria, Penicillium, Acremonium, Mucor, and Aspergillus are the frequent filamentous fungi colonizing as epiphytes and endophytes (Arnold et al. 2000; Inacio et al. 2002; Rana et al. 2019a, b, c).

However, the culture-independent strategy is the best to investigate the diversity and distribution of specific bacterial groups of interest (Miyamoto et al. 2004; Sessitsch et al. 2006). Other than the 16S/18S rDNA sequences, multiplex terminal restriction fragment length polymorphism (TRFLP) has been used to analyze several phylogenetic groups or functional genes in the microenvironment (Singh et al. 2006). Soils, water, air, tree buds, and plant debris from the previous crops are the sources for microbes in phyllosphere (Manceau and Kasempour 2002). Those microorganisms may be habited in phyllosphere either transient or residual epiphytes (Suslow 2002; Zak 2002). The atmospheric microflora, rainfall, humidity, wind, etc. can directly influence the transients of microorganisms to the phyllosphere (Lighthart 1997). During the plant growth period, the epiphytic bacterial population will increase in quantity (Inacio et al. 2002). The microorganisms on the seed or roots may be established as epiphytes or endophytes (Wulff et al. 2003). Some epiphytes may be injected into the internal space of the leaf and colonize as endophytes. The distribution pattern of the phyllosphere microorganisms is not even, mostly bacteria colonize at the epidermal wall junctions, specifically in the grooves and the veins or stomata or at the base of trichomes (Melotto et al. 2008), also found in the cuticle layer, near hydathodes and stomatal pits (Aung et al. 2018). The microbial load is higher at the lower leaf surface perhaps the lower leaf surface contains thin cuticle, stomata, and/or trichomes (Beattie and Lindow 1999). Mostly, all microorganisms that appear in the phyllosphere are capable to colonize and grow (Whipps et al. 2008), and it disperses throughout the surface by rain splash, bounce-off, wash-off, water movement, or removal by insects or pest (Kinkel 1997; Yang et al. 2001; Lambais et al. 2006). 


\subsubsection{Bacterial Diversity in the Phyllosphere}

Phyllosphere is a heterogeneous environment (Koskella 2013), bacteria are considered the most abundant inhabitants of the leaves, and its average number is being around $10^{6}-10^{8}$ cells $\mathrm{cm}^{-2}$ (Andrews and Harris 2000; Hirano and Upper 2000). But the population of epiphytic bacteria differs depending on the plant species and its surrounding environment. The variation is mainly due to the physical and nutritional conditions of the phyllosphere. Commonly, the broad-leaf plants have the highest number of bacteria than the grasses or waxy broad-leaf plants (Kinkel et al. 2000).

Generally, the phyllosphere contains four major phyla of bacteria such as the Proteobacteria, Firmicutes, Bacteroides, and Actinobacteria (Kembel et al. 2014; Durand et al. 2018). Methylotrophic bacteria are predominant in phyllosphere which includes genera such as Methylobacterium, Methylophilus, Methylibium, Hyphomicrobium, Methylocella, Methylocapsa, and Methylocystis (Mizuno et al. 2013; Iguchi et al. 2013; Kwak et al. 2014; Krishnamoorthy et al. 2018). Methylobacterium and Sphingomonas are the predominant genera belonging to the class alphaproteobacteria reported in several plant phyllospheres (Delmotte et al. 2009; Kumar et al. 2019a). The bacterial community organization on phyllosphere is controlled by specific assemblage regulations (Buee et al. 2009; Reinhold-Hurek et al. 2015). Normally, soil type, plant genotype and species, immune system of the plant, age, climatic condition, and the geographic region are the factors forcing the bacterial community assembly (Leff et al. 2015; Zarraonaindia et al. 2015; Copeland et al. 2015). Extensive studies are available for the soil and rhizosphere bacterial community on phyllosphere bacterial colonization in Arabidopsis thaliana (Bodenhausen et al. 2013; Maignien et al. 2014; Bai et al. 2015; Muller et al. 2015) and maize (Peiffer et al. 2013). Proteobacteria, Actinobacteria, and Bacteroidetes are the most abundant phyla colonizing the leaf and root of $A$. thaliana (Delmotte et al. 2009; Redford et al. 2010; Bodenhausen et al. 2013). Massilia, Flavobacterium, Pseudomonas, and Rathayibacter are a prevalent bacterial genus in A. thaliana (Bodenhausen et al. 2013), Deinococcus thermus on tree phyllosphere (Redford et al. 2010), and Bacillus and Pantoea dominate the lettuce (Rastogi et al. 2012).

Kembel et al. (2014) studied the bacterial communities on tropical tree leaves, around 400 bacterial taxa the phyllosphere has been dominated with Actinobacteria, Alpha-, Beta-, and Gammaproteobacteria, and Sphingobacteria. However, Archaea is the profuse members of the plant-associated microbe, commonly Thaumarchaeota, Crenarchaeota, and Euryarchaeota make the endophytic mode of life in plants (Müller et al. 2015). Durand et al. (2018) characterized the bacterial genera such as Methylobacterium, Kineococcus, Sphingomonas, and Hymenobacter of the phylum Firmicutes from the leaf surface. The phyllosphere of the grapevine contains Acinetobacter, Bacillus, Citrobacter, Curtobacterium, Enterobacter, Erwinia, Frigoribacterium, Methylobacterium, Pantoea, Pseudomonas, and Sphingomonas as dominant genera (Kecskeméti et al. 2016). Steven et al. (2018) characterized Pseudomonas and Enterobacteriaceae as predominant taxa from apple. Several studies revealed Pseudomonas as the most abundant genus of phyllosphere region (Aleklett et al. 2014; 
Kecskeméti et al. 2016; Steven et al. 2018). Seed coat associated bacteria that have been reported in phyllosphere are mainly Actinobacteria, Bacteroidetes, Firmicutes, and Proteobacteria (Johnston-Monje and Raizada 2011; Rodríguez-Escobar et al. 2018).

The most notable bacterial pathogen is Pseudomonas syringae, it causes diseases in a wide range of economically important plant species (Mansfield et al. 2012; Morris et al. 2013; Burch et al. 2014). Hamd Elmagzob et al. (2019) identified taxa such as Rhizobiales, Clostridiales, Pseudomonadales, Burkholderiales, Bacteroidales, Enterobacteriales, Rhodocyclales, Sphingomonadales, Lactobacillales, and Bacillales from the leaves of Cinnamomum camphora (L.) Presl. Several studies reported diazotrophic bacteria on phyllosphere (Fürnkranz et al. 2008; Rico et al. 2014). Diazotrophic bacteria can use atmospheric dinitrogen $\left(\mathrm{N}_{2}\right)$ as nitrogen source for its metabolic activities. Bacterial diazotrophic include Beijerinckia, Azotobacter, Klebsiella, and Cyanobacteria (e.g., Nostoc, Scytonema, and Stigonema). Diazotrophic nitrogen fixation has been reported in many species which contains an enzyme nitrogenase (encoded by nif genes) (Rico et al. 2014). Recently, 16 s rRNA gene-based high-throughput sequencing technology has been used for the diversity analysis of phyllosphere, for example, the distribution of endophytic bacteria of $C$. camphora (L.) Presl leaves has been analyzed by 16S rRNA gene metagenomics, revealing Proteobacteria, Firmicutes, Bacteroidetes, Actinobacteria, Gemmatimonadetes, Acidobacteria, Planctomycetes, Chloroflexi, and Fusobacteria are the major phyla of the polymicrobial community (Hamd Elmagzob et al. 2019).

\subsubsection{Fungal Microbiota of Phyllosphere}

Fungi are saprophytic and they may be associated with plants either epiphytic or endophytic, and mostly they are known for their pathogenesis on plant system (Vořŕšková and Baldrian 2013; Yadav et al. 2019b, c, d). There are several reports revealed that phyllosphere fungi have a profound role in the residing host. Both epiphytic and endophytic fungi inhabiting the leaf are of high species diversity with diverse metabolic functions (Yao et al. 2019), such as leaf litter decomposition and recycling the carbon and nitrogen (Kannadan and Rudgers 2008; Guerreiro et al. 2018). In general, endophytic fungi can help plant growth and also provide resistance to biotic (pathogens) and abiotic (drought and salinity) stresses, (Arnold et al. 2007; Purahong and Hyde 2011; Guerreiro et al. 2018; Yadav et al. 2018c). In culturedependent approaches, several fungal species have been isolated from small herbs to larger woody plants. Inácio et al. (2010) reported that the density of yeast-like fungi may vary from plant to plant and approximately $5 \times 10^{4}$ cells cm $\mathrm{cm}^{-2}$. Aureobasidium pullulans are yeast-like fungi abundant in phyllosphere (Cordier et al. 2012; Setati et al. 2012). Apart from yeast-like fungi, many filamentous fungi have been reported from health as well as infected plant leaves. Through the culture-dependent method, Ripa et al. (2019) isolated Aspergillus niger, Fusarium oxysporum, Penicillium aurantiogriseum, Fusarium incarnatum, Alternaria alternata, Alternaria 
tenuissima, Cladosporium cladosporioides, Talaromyces funiculosus, Aspergillus flavus, Trichoderma aureoviride, Trichoderma harzianum, Penicillium janthinellum, Fusarium proliferatum, Fusarium equiseti, and Aspergillus stellatus from wheat plant.

Dhayanithy et al. (2019) isolated twenty endophytic fungi from the leaves and stem of Catharanthus roseus, among them Colletotrichum, Alternaria, and Chaetomium were the dominant genera. Many of them make endophytic association begin with epiphytic initiation (Rodriguez et al. 2009; Porras-Alfaro and Bayman 2011), and some endophytes later turned to pathogens. The olive tree phyllosphere is found to be highly diverse having more than 149 genera and 68 families of fungi (Martins et al. 2016) in a Mediterranean ecosystem (Portugal), but Abdelfattah et al. (2015) reported only 13 endophytic fungal taxa in the leaves and twigs of olive trees. There has been a discrepancy to understand the phyllosphere fungi as endophytic or epiphytic, occasionally it is uncertain, for the reason that some can reside both epiphytic and endophytic modes of association. In general, phyllosphere endophytic fungi are the epiphytic habitats and are penetrated into the plant tissues to form an endophytic association (Kharwar et al. 2010; Porras-Alfaro and Bayman 2011). Though they are phyllospheric, the soil has acted as a reserve for these potential endophytic inoculums of the above-ground organs (Zarraonaindia et al. 2015). For example, Ascochyta sp. and Fagus crenata B1 (Osono 2006), Colletotrichum gloeosporioides and Phomopsis sp. (Rivera-Vargas et al. 2006; Twizeyimana et al. 2013), and Table 5.1 listed some examples of phyllosphere fungal endophytes.

Osono (2008) reported that endophytic Colletotrichum gloeosporioides and $C$. acutatum, and epiphytes Pestalotiopsis sp., Aureobasidium pullulans, Phoma sp., and Ramichloridium sp. are the phyllosphere fungi in the plant Camellia japonica. However, the abundance and diversity of the fungi differ in plant species as well as in different eco-climatic conditions. Moreover, seasonal and leaf age-dependent variations also occur in the epiphytic and endophytic phyllosphere fungal assembly, for example, Geniculosporium sp. is varied in leaf age, and Cladosporium cladosporioides has been varied in both season and leaf age of the plant Camellia japonica (Osona 2008). Phyllosphere fungi play an important function in mineral absorption and mineral recycling process, specifically carbon, nitrogen, and phosphorus recycling in the forest ecosystem. Therefore, the study about the phyllosphere fungi and its physiology with host plant is important.

\subsubsection{Actinomycetes Diversity in Phyllosphere}

In addition to bacterial diversity, actinobacteria share a considerable interest in epiphytic and endophytic life forms in the phyllosphere. They are soil-inhabiting saprophytic microbes and have been extensively studied for their therapeutic secondary metabolites. This versatile group of gram-positive bacteria has adapted to diverse environments including the phyllosphere of the plant (Singh et al. 2018). Some actinobacteria form symbiotic association residing in plant tissues have generated 
Table 5.1 Phyllosphere fungal endophytes

\begin{tabular}{|c|c|c|c|}
\hline Endophytic fungi & Host plant & Type & References \\
\hline $\begin{array}{l}\text { Aspergillus, } \\
\text { Phomopsis, } \\
\text { Wardomyces, } \\
\text { Penicillium }\end{array}$ & $\begin{array}{l}\text { Euterpe oleracea } \\
\text { (palm) }\end{array}$ & Palm & Rodrigues (1994) \\
\hline Ramularia spp. & $\begin{array}{l}\text { Vitis riparia } \\
\text { (grapevine) }\end{array}$ & Wild & Kernaghan et al. (2007) \\
\hline $\begin{array}{l}\text { Absidia sp., } \\
\text { Aspergillus sp., } \\
\text { Cladosporium sp., } \\
\text { Cunninghamella sp., } \\
\text { Fusarium sp., } \\
\text { Nigrospora sp., } \\
\text { Paecilomyces sp., } \\
\text { Penicillium sp., } \\
\text { Rhizopus sp., }\end{array}$ & Meyna spinosa Roxb. & Medicinal plant & $\begin{array}{l}\text { Bhattacharyya et al. } \\
\text { (2017) }\end{array}$ \\
\hline $\begin{array}{l}\text { Penicillium } \\
\text { chrysogenum, and } \\
\text { Penicillium crustosum }\end{array}$ & Teucrium polium & Medicinal plant & El-Din Hassan (2017) \\
\hline $\begin{array}{l}\text { Alternaria alternata, } \\
\text { Setosphaeria sp., } \\
\text { Cochliobolus sp., } \\
\text { Alternaria sp. Phoma } \\
\text { herbarum, Davidiella } \\
\text { tassiana, } \\
\text { Botryosphaeria } \\
\text { dothidea, Ulocladium } \\
\text { alternariae, Phoma } \\
\text { macrostoma var. } \\
\text { incolorata, Phoma } \\
\text { exigua var. exigua, } \\
\text { Cladosporium } \\
\text { cladosporioides strain, } \\
\text { Botryosphaeria sp., } \\
\text { Guignardia } \\
\text { mangiferae, } \\
\text { Pyrenophora } \\
\text { tritici-repentis, } \\
\text { Guignardia alliacea, } \\
\text { Rhizopus oryzae }\end{array}$ & Catharanthus roseus & Medicinal plant & Sreekanth et al. (2017) \\
\hline
\end{tabular}

(continued)

enormous significance to the host and its environment through their novel metabolites. Diversity and distribution of endophytic actinobacteria have been largely documented, from medicinal plants, crop plants, and some other terrestrial plants (Qin et al. 2011; Masand et al. 2015; Dinesh et al. 2017; Nalini and Prakash 2017). Several species of actinobacteria have been reported from plants such as Triticum aestivum, Lupinus termis, Lobelia clavatum, Acacia auriculiformis, Aquilaria crassna, Oryza 
Table 5.1 (continued)

\begin{tabular}{|c|c|c|c|}
\hline Endophytic fungi & Host plant & Type & References \\
\hline $\begin{array}{l}\text { Ascomycetes: } \\
\text { Trichoderma, } \\
\text { Penicillium, Fusarium, } \\
\text { and Aspergillus. } \\
\text { Non-ascomycetes: } \\
\text { Mucor } \\
\text { (Mucoromycota) and } \\
\text { Schizophyllum } \\
\text { (Basidiomycota) }\end{array}$ & Stanhopea tigrina & Orchid & $\begin{array}{l}\text { Salazar-Cerezo et al. } \\
\text { (2018) }\end{array}$ \\
\hline $\begin{array}{l}\text { Trichothecium sp., } \\
\text { Epicoccum nigrum, } \\
\text { Alternaria alternaria, } \\
\text { Alternaria } \\
\text { arborescens, } \\
\text { Nigrospora sphaerica, } \\
\text { Epicoccum sp., } \\
\text { Alternaria sp. } \\
\text { Nigrospora sp., } \\
\text { Colletotrichum } \\
\text { gloeosporioides, } \\
\text { Fusarium oxysporum, } \\
\text { Trichothecium roseum }\end{array}$ & $\begin{array}{l}\text { Vitis vinifera (Grape } \\
\text { fruit cells) }\end{array}$ & Fruit plant & Huang et al. (2018) \\
\hline Aspergillus japonicus & Euphorbia indica L. & Wild plant & Ismail et al. (2018) \\
\hline $\begin{array}{l}\text { Alternaria spp., } \\
\text { Trichophyton spp., } \\
\text { Geotrichum spp., } \\
\text { Candida spp., } \\
\text { Aspergillus spp., } \\
\text { Aureobasidium spp., } \\
\text { Fusarium spp., } \\
\text { Exserohilum spp., } \\
\text { Curvularia spp., } \\
\text { Coccidioides spp., } \\
\text { Bipolaris spp. }\end{array}$ & $\begin{array}{l}\text { Epipremnum aureum, } \\
\text { Azadirachta indica, } \\
\text { Piper betle, } \\
\text { Catharanthus roseus, } \\
\text { Ficus religiosa, Musa } \\
\text { acuminate, Ficus } \\
\text { Benghalensis, Ficus } \\
\text { racemosa, Calotropis } \\
\text { procera, Ocimum } \\
\text { tenuiflorum }\end{array}$ & Medicinal plant & $\begin{array}{l}\text { Jariwala and Desai } \\
\text { (2018) }\end{array}$ \\
\hline $\begin{array}{l}\text { Nigrospora sphaerica, } \\
\text { Acremonium } \\
\text { falciforme, Allomyces } \\
\text { arbuscula, Penicillium } \\
\text { chrysogenum, } \\
\text { Acrophialophora sp, } \\
\text { Mycelia sterilia }\end{array}$ & Litsea cubeba & Medicinal plant & Deka and Jha (2018) \\
\hline
\end{tabular}


Table 5.1 (continued)

\begin{tabular}{|c|c|c|c|}
\hline Endophytic fungi & Host plant & Type & References \\
\hline $\begin{array}{l}\text { Colletotrichum } \\
\text { gloeosporioides f. sp. } \\
\text { camelliae and } \\
\text { Pleosporales sp. }\end{array}$ & Camellia sinensis & Tea & Win et al. (2019) \\
\hline $\begin{array}{l}\text { Tremellales, } \\
\text { Davidiellaceae, } \\
\text { Basidiomycota, } \\
\text { Rhodotorula, } \\
\text { Tremellales, Meria, } \\
\text { Cryptococcus, } \\
\text { Cladosporium, } \\
\text { Acaromycetes, } \\
\text { Erythrobasidium, etc. }\end{array}$ & $\begin{array}{l}\text { Aegiceras } \\
\text { corniculatum } \\
\text { (Myrsinaceae), } \\
\text { Avicennia marina } \\
\text { (Verbenaceae), } \\
\text { Bruguiera } \\
\text { gymnorrhiza, } \\
\text { Kandelia candel and } \\
\text { Rhizophora stylosa } \\
\text { (Rhizophoraceae), and } \\
\text { Excoecaria agallocha } \\
\text { (Euphorbiaceae) }\end{array}$ & Mangrove & Yao et al. (2019) \\
\hline
\end{tabular}

sativa, Xylocarpus granatum, and Elaeagnus angustifolia from various environments like arid, semiarid, and mangrove are Actinoplane missouriensis, Actinoallomurus acacia, Actinoallomurus coprocola, Actinomadura glauciflava, Amycolatopsis tolypomycina, Actinoallomurus oryzae, Jishengella endophytica, Kribbella sp., Microbispora mesophila, Microbispora sp., Micromonospora sp., Nocardioides sp., Nocardia alba, Nonomuraea rubra, Micromonospora sp. Nonomuraea sp., Pseudonocardia sp., Planotetraspora sp., Pseudonocardia endophytica, Pseudonocardia halophobica, Streptomyces sp., and Streptomyces javensis (Coombs and Franco 2003; Thamchaipenet et al. 2010; Chen et al. 2011; Xie et al. 2011; Yadav 2017; Yadav and Yadav 2018). Reports revealed that the actinomycetes diversity in phyllosphere is high in the tropical and temperate ecosystem (Strobel and Daisy 2003; Yadav et al. 2018b; Yadav and Yadav 2019). Moreover, the physiology of the plant and the environment determines the actinobacterial association in plants and allows them to establish endophytic life (Du et al. 2013). Some important actinobacterial diversity in various plant sources is discussed in the following (Table 5.2).

\subsection{Mechanism of Microbial Interaction with the Phyllosphere}

The leaf physiology determines the microbial diversity and abundance on the phyllosphere. It establishes the microhabitat where the microorganisms adapt to their physiology to survive in this habitat (Staley et al. 2014; Shiraishi et al. 2015). The epiphytic microbes formed as colonial form, which gives protection to the microorganisms from this harsh microhabitat (Lindow and Brandl 2003; Remus-Emsermann 
Table 5.2 Diversity of endophytic actinobacteria

\begin{tabular}{|c|c|c|c|}
\hline Endophytic actinobacteria & Host plant & Habitat & References \\
\hline $\begin{array}{l}\text { Microbispora sp., } \\
\text { Micromonospora sp., } \\
\text { Nocardioides sp., Streptomyces } \\
\text { sp., }\end{array}$ & Triticum aestivum & Arid & $\begin{array}{l}\text { Coombs and } \\
\text { Franco }(2003)\end{array}$ \\
\hline Actinoplane missouriensis & Lupinus termis & Arid & $\begin{array}{l}\text { El-Tarabily } \\
(2003)\end{array}$ \\
\hline Pseudonocardia endophytica & Lobelia clavatum & Arid & $\begin{array}{l}\text { Chen et al. } \\
(2009)\end{array}$ \\
\hline $\begin{array}{l}\text { Actinoallomurus acaciae, } \\
\text { Streptomyces sp., } \\
\text { Actinoallomurus coprocola, } \\
\text { Amycolatopsis tolypomycina, } \\
\text { Kribbella sp., Microbispora } \\
\text { mesophila }\end{array}$ & Acacia auriculiformis & Arid & $\begin{array}{l}\text { Thamchaipenet } \\
\text { et al. (2010) }\end{array}$ \\
\hline $\begin{array}{l}\text { Actinomadura glauciflava, } \\
\text { Pseudonocardia halophobica, } \\
\text { Nocardia alba, Nonomuraea } \\
\text { rubra, Streptomyces javensis }\end{array}$ & Aquilaria crassna & Mangrove & $\begin{array}{l}\text { Nimnoi et al. } \\
\text { (2010) }\end{array}$ \\
\hline Actinoallomurus oryzae & Oryza sativa & Aquatic & $\begin{array}{l}\text { Indananda } \\
\text { et al. (2011) }\end{array}$ \\
\hline Jishengella endophytica & Xylocarpus granatum & Mangrove & $\begin{array}{l}\text { Xie et al. } \\
(2011)\end{array}$ \\
\hline $\begin{array}{l}\text { Micromonospora } \mathrm{sp} . \\
\text { Nonomuraea sp., } \\
\text { Pseudonocardia } \mathrm{sp.} \\
\text { Planotetraspora } \text { sp. }\end{array}$ & Elaeagnus angustifolia & Arid & $\begin{array}{l}\text { Chen et al. } \\
\text { (2011) }\end{array}$ \\
\hline Streptomyces phytohabitans & Curcuma phaeocaulis & Arid & $\begin{array}{l}\text { Bian et al. } \\
(2012)\end{array}$ \\
\hline Nonomuraea solani & Solanum melongena & Arid & $\begin{array}{l}\text { Wang et al. } \\
\text { (2013b) }\end{array}$ \\
\hline $\begin{array}{l}\text { Actinoplanes hulinensis, } \\
\text { Streptomyces harbinensi, } \\
\text { Wangella harbinensis }\end{array}$ & Glycine $\max$ & Arid & $\begin{array}{l}\text { Jia et al. } \\
\text { (2013), Liu } \\
\text { et al. (2013), } \\
\text { Shen et al. } \\
\text { (2013) }\end{array}$ \\
\hline Micromonospora sonneratiae & Sonneratia apetala & Mangrove & Li et al. (2013) \\
\hline Modestobacter roseus & Salicornia europaea & Saline & $\begin{array}{l}\text { Qin et al. } \\
\text { (2013) }\end{array}$ \\
\hline $\begin{array}{l}\text { Promicromonospora } \\
\text { endophytica }\end{array}$ & Eucalyptus microcarpa & Arid & $\begin{array}{l}\text { Kaewkla and } \\
\text { Franco (2013) }\end{array}$ \\
\hline $\begin{array}{l}\text { Blastococcus endophyticus, } \\
\text { Plantactinospora endophytica }\end{array}$ & Camptotheca acuminate & Arid & $\begin{array}{l}\text { Zhu et al. } \\
\text { (2013) }\end{array}$ \\
\hline
\end{tabular}


Table 5.2 (continued)

\begin{tabular}{|c|c|c|c|}
\hline Endophytic actinobacteria & Host plant & Habitat & References \\
\hline $\begin{array}{l}\text { Actinoplanes brasiliensis, } \\
\text { Couchioplanes caeruleus, } \\
\text { Gordonia otitidis, Micrococcus } \\
\text { aloeverae, Streptomyces } \\
\text { zhaozhouensis }\end{array}$ & Aloe arborescens & Arid & He et al. (2014) \\
\hline $\begin{array}{l}\text { Micromonospora } \\
\text { schwarzwaldensis Streptomyces } \\
\text { sp., Wenchangensis }\end{array}$ & Centella asiatica & Mangrove & $\begin{array}{l}\text { Ernawati et al. } \\
\text { (2016) }\end{array}$ \\
\hline $\begin{array}{l}\text { Glutamicibacter halophytocola, } \\
\text { Kineococcus endophytica, } \\
\text { Streptomyces sp., }\end{array}$ & Limonium sinense & Saline & $\begin{array}{l}\text { Feng et al. } \\
(2017)\end{array}$ \\
\hline Marmoricola endophyticus & Thespesia populnea & Mangrove & $\begin{array}{l}\text { Jiang et al. } \\
\text { (2017) }\end{array}$ \\
\hline $\begin{array}{l}\text { Allostreptomyces } \\
\text { psammosilenae }\end{array}$ & Psammosilene tunicoides & Arid & $\begin{array}{l}\text { Huang et al. } \\
\text { (2017) }\end{array}$ \\
\hline Micromonospora terminaliae & Terminalia mисronata & Mangrove & $\begin{array}{l}\text { Kaewkla et al. } \\
\text { (2017) }\end{array}$ \\
\hline $\begin{array}{l}\text { Nocardiopsis sp., } \\
\text { Pseudonocardia } \mathrm{sp} . \\
\text { Streptomyces sp., }\end{array}$ & Dracaena cochinchinensis & Semiarid & $\begin{array}{l}\text { Salam et al. } \\
(2017)\end{array}$ \\
\hline Mangrovihabitans endophyticus & Bruguiera sexangula & Mangrove & $\begin{array}{l}\text { Liu et al. } \\
\text { (2017) }\end{array}$ \\
\hline $\begin{array}{l}\text { Actinoplanes sp., Agrococcus } \\
\text { sp., Amnibacterium sp., } \\
\text { Brachybacterium sp., } \\
\text { Brevibacterium sp., Citricoccus } \\
\text { sp., Curtobacterium sp., } \\
\text { Dermacoccus sp., } \\
\text { Glutamicibacter sp., Gordonia } \\
\text { sp., Isoptericola sp., Janibacter } \\
\text { sp., Kocuria sp., Leucobacter } \\
\text { sp., Mycobacterium sp., } \\
\text { Micrococcus sp., Nocardioides } \\
\text { sp., Kineococcus sp., } \\
\text { Kytococcus sp., Marmoricola } \\
\text { sp., Microbacterium sp. } \\
\text { Micromonospora, sp., Nocardia } \\
\text { sp., Nocardiopsis sp., } \\
\text { Pseudokineococcus, sp., } \\
\text { Sanguibacter sp., Streptomyces } \\
\text { sp., Verrucosispora sp., }\end{array}$ & $\begin{array}{l}\text { Avicennia marina, } \\
\text { Aegiceras corniculatum, } \\
\text { Kandelia obovota, } \\
\text { Bruguiera gymnorrhiza, } \\
\text { and Thespesia populnea }\end{array}$ & Mangrove & $\begin{array}{l}\text { Jiang et al. } \\
(2018)\end{array}$ \\
\hline Glycomyces anabasis & Anabasis aphylla & Arid & $\begin{array}{l}\text { Zhang et al. } \\
\text { (2018) }\end{array}$ \\
\hline
\end{tabular}


et al. 2012). Commonly, bacteria develop larger sized colonial association on the leaf surface, especially at veins as well as the groves of epidermal cells (Morris et al. 1997; Hirano and Upper 2000). The epidermal grooves are rich in nutrients specifically sugar and water. This region is less waxy cuticle, usually the leaf surface is fully coved with waxy cuticle which prevents the permeability and wettability of the leaf surface and regulates the colonization of the microbes on phyllosphere (Lindow and Brandl 2003; Burch et al. 2014).

The leaf surface water droplets diffuse the waxy cuticle and improve the permeability by which the compounds are diffused from the apoplast to phyllosphere surface (Schreiber 2005). These leached compounds and water on the phyllosphere are making the availability of nutrients to the microorganisms. Most commonly, the flow of water from the stomata (transpiration) is increasing the permeability and wettability of guard cells and its surface cuticles (Schönherr 2006). Hence, higher permeation of the cuticle layer permits the microbes to colonize densely (Krimm et al. 2005). Moreover, the surface bacteria are able to produce certain compounds like biosurfactants (syringafactin produced by Pseudomonas syringae) (Krimm et al. 2005; Burch et al. 2014) which can modify the cuticle surfaces of the leaf and establish its association. This can facilitate water availability and alter sugar availability that can improve living conditions for epiphytic bacterial growth (Lindow and Brandl 2003; Van der Wal and Leveau 2011). Epiphytes such as Pseudomonas sp., Stenotrophomonas sp., and Achromobacter increase the water permeability of the lipophilic cuticle present in Hedera and Prunus, which increases the availability of the compounds at the phyllosphere which will improve the epiphytic fitness on the leaf surface (Schreiber et al. 2005).

It has been experimentally proved in the bean phyllosphere containing fructose facilitates the growth of Erwinia herbicola and Pantoea agglomerans (RemusEmsermann et al. 2013; Tecon and Leveau 2016). However, irregular distribution of fructose differentially promotes the P. eucalypti population on bean leaves (Mercier and Lindow 2000; Leveau and Lindow 2001; Remus-Emsermann et al. 2011). These studies suggested that the permeated carbon sources on the leaf surface are merrily exploited by the epiphytic microorganisms for their growth and multiplication. At the same time, the phyllosphere microbial population can influence the modulation of the physicochemical properties of the leaf with the help of both biotic and abiotic surroundings (Bringel and Couée 2015; Ohshiro et al. 2016; Quan and Liang 2017). Soil microbial community may also influence the determination of phyllosphere microbial diversity. However, the microbes can construct the niches in the phyllosphere microhabitat wherein it can sustain and establish its population steadily (Agler et al. 2016; San Roman and Wagner 2018). Recent studies revealed the special relationships between the bacterial species in the phyllosphere community. Presence of sugars and nutrients in this environment significantly change the individual bacterial cells within the microbial aggregates (Fig. 5.2) would spatially be established with cell-to-cell interactions along with direct physical interactions (Levy et al. 2018; Tecon et al. 2018). The community structure is organized based on the driven factors such as dispersal, selection of microbes, diversification, and 
ecological drift. The fitness of the community is due to internal (strain types) and external determinants (environment) of the phyllosphere (Schlechter et al. 2019).

In general, the internal factors of the community are based on the microbial relationship within the aggregates. The microbes usually have either commensal or antagonistic or mutualistic or cooperative association by which the community structure can be established. Both cooperative and mutualistic microbial interactions shape the community structure as well as to develop larger colonial association containing the maximum microbial population. While commensals have weak interactive partners in the community, they are randomly distributed in the habitat. The commensals should not influence the interactive association within the structured community (Stubbendieck et al. 2016). Besides, antagonistic microbes have a negative interaction within the community, one can outcompete the other and the sensitive microbes have been eliminated from the environment. The effect of cooperative microbial interactions on the phyllosphere community structure establishment is not demonstrated (Schlechter et al. 2019).

Bacteria can ascertain the cell-to-cell communication system and establish a larger community structure with heterogeneous populations, usually with mutualistic and cooperative partners. However, some kind of mutualistic relationship may occur between rapid growing bacteria and pathogenic fungi, which leads to cause superficial infection on the host plant which increases the nutrient accessibility of the bacteria to rich its population (Suda et al. 2009; Zeilinger et al. 2016; Amine Hassani et al. 2018). Inversely, fungal-fungal interactions seem to decrease the bacterial population, for example, oomycete species Dioszegia sp. and Albugo sp. outcompete the bacterial microbiota on A. thaliana leaf (Chou et al. 2000; Agler et al. 2016). Moreover, competitive interactions of microbes involve negative effects on at least one species of the habitat. Some competitive microbes produce certain toxic chemical substances (antibiotics and siderophores) as secondary metabolites which pose a negative effect on its competitor microbes. The best example of such interaction is a gram-negative Pantoea agglomerans bacteria which inhibit the growth of Erwinia amylovora, a phytopathogen of apple by antibiotic activity (Wright et al. 2001; Pusey et al. 2011).

Generally, the competition of microbes is mainly for their nutrition and space. The phyllosphere is a nutrient-limited environment, wherein the competitive partner has compromised their growth by either coexisting or excluded from the site (Saleem et al. 2017). Besides, the phyllosphere is greatly colonized by both oligotrophic and competitive microbes which play an important role in community structure formation (Schlechter et al. 2019). However, the key factors of the phyllosphere community assemblage are currently vague. Hence, more studies required to find the key factors determining the phyllosphere community structure assemblage.

\subsection{Factors Controlling Phyllosphere Microbiomes}

Once microbes arrived at the phyllosphere, a variety of factors resolve whether microbial cells are competent to colonize the leaf and become confined. Colony 
establishment depends on the leaf-atmosphere environmental interaction with the residing microorganisms in the phyllosphere. At the beginning, the microbe reaches the cuticle layer, a waxy surface that protects the leaf from the pathogens. In general, cuticle restricts the microbial association due to the functions such as barrier, reducing water and solute lass, aqueous pollution, reflectance to minimize the temperature, conferring water repellent, etc. (Beattie 2002; Whipps et al. 2008). The whole-cell biosensor-based study revealed the available nutrients on the leaf surface facilitate the growth of residing microbes at a limited level (Miller et al. 2001). This was confirmed by the microscopic observation of leaf surfaces, at the low nutrient region contains less dense microbial colonization than the nutrient-rich surface (Monier and Lindow 2005). Naturally, nutrient enrichment may happen by pollen deposits and honeydew at the phyllosphere surface (Lindow and Brandl 2003), besides plant leaves release a large array of volatile organic substances into the margin layer around leaves (Jackson et al. 2006). Nutrients that include $\mathrm{CO}_{2}$, acetone, terpenoids, aldehydes, alcohols, long-chain hydrocarbons, sesquiterpenoids, and nitrogen-containing compounds (Whipps et al. 2008) are available nutrients for microbial growth. Some of the compounds may act as growth inhibitor or toxic to microbial growth (Dingman 2000; Shepherd et al. 2005). Hence, microbes establish several adaptive mechanisms for maintaining their growth in adverse conditions.

\subsubsection{Microbial Adaptations in Phyllosphere Environment}

Microbes like bacteria establishing colonies at the phyllosphere are limited by various factors including both biotic and abiotic. Abiotic factors such as the available nutrient (Delmotte et al. 2009), seasonal variation, rainfall, temperature, plant immunity, and competitor microbes (Rastogi et al. 2013) are influencing surveillance of microbes in the phyllosphere. Metaproteomic studies on the leaf surface communities have been identified as microbes producing vitamins and siderophores which give adaptation to the microbes at the environment. For example, phyllosphere of soybean, clover, and Arabidopsis plants largely colonized by Sphingomonas and Methylobacterium provides vitamins and siderophores to the plant (Green 2006; Delmotte et al. 2009) and it competes for other microbes. Methylobacterium spp. are involved in the assimilation of methanol at the phyllosphere, a by-product of demethylated pectin during the cell wall metabolism of the plant (Galbally and Kirstine 2002; Delmotte et al. 2009), and it gives epiphytic fitness to the microbes. Proteome studies revealed that some unique properties of rhizosphere bacteria have been found in the phyllosphere microbiota. For example, genes of methanol dehydrogenase and formaldehyde-activating enzyme (of Rhizosphere Methylobacterium spp.) and nitrogen fixation (Rhizobium sp.) are also reported in both phyllosphere and rhizosphere samples of rice (Knief et al. 2012). Gourion et al. (2006) observed upregulation of methylotrophic proteins such as MxaF and Fae and stress-related protein PhaA during epiphytic growth of Methylobacterium extorquens. 
Phyllosphere colonization may occur in two different habitats, (1) the surface (epiphytic) and (2) the apoplast or leaf interior (endophytic). During the epiphytic life, many of the environmental factors regulate the growth such as solar radiation, temperature, water availability, nutrient, humidity, etc., whereas the endophytes are challenged with a plant defense mechanism. A bacteria colonizing at both habitats may differentially express their genes, for example, $P$. syringae pv. syringae B728a at epiphytic growth express the genes involved in motility, chemosensing, phosphate mobilization, and utilization of tryptophan which is higher than in endophytic growth (Yu et al. 2013). However, the secondary metabolite (syringomycin, syringopeptin) production was higher in the endophytic stage. One such adaptation is the production of pigments, bacteria such as Pseudomonas, Sphingomonas, and Methylobacterium produce pigmentation by which they give protection against UV light (Lindow and Brandl 2003). Presence of extracellular polysaccharide is another protective measure of plant-bacteria against desiccation and osmotic stress (Monier and Lindow 2004). Delmotte et al. (2009) found several stress-resistant proteins (PhyR and EcfG) from the phyllosphere of soybean, clover, and Arabidopsis through metaproteogenomic survey. Flagellin-like protein is high in pseudomonas at the epiphytic growth which enables the bacteria to access the nutrition by the chemostatic model (Yu et al. 2013).

\subsubsection{Plant Immunity/Responses to Control Microbial Colonization}

The plant has its immune system which plays an important role in determining microbial assembly (Jacoby et al. 2017). Plants contain two layers of defense, the primary immunity is named pattern-triggered immunity (PTI), it has a conserved molecule named microbe/pathogen-associated molecular patterns (MAMPs/PAMPs). The PTI is a localized immunity mediated at the plasma membrane containing pattern recognition receptors (Monaghan and Zipfel 2012; Wang et al. 2019). The MAMP/PAMP limits the growth of bacterial pathogens. For example, the flagellin-sensitive receptor 2 (FLS2) is a pattern receptor which recognizes the $P$. syringae pathovar (pv.) bacterial flagellin (flg22) (Chinchilla et al. 2006; Newman et al. 2013; Trdá et al. 2015). However, the plant response to limits its defense against non-pathogenic bacteria is still unknown. The effector's protein-mediated destabilization of plant immunity and immune escape is also reported (Jones and Dangl 2006; Cui et al. 2009). Plant immunity is targeted with specific proteins, which involves the selfprotection against the microbial association has been deactivated by the interaction of microbial effector proteins and it makes protein-protein networks (Bogdanove 2002; Snelders et al. 2018). Besides, plants have evolved with intracellular receptor molecules called nucleotide-binding leucine-rich repeat proteins (NLRs), which either openly or ultimately recognize effector proteins to give the second layer of plant immunity named effector-triggered immunity (ETI) (Jacob et al. 2013; Wu et al. 
2014). Both PTI and ETI generate more specific and diverse immunity against phyllosphere microflora. Beneficial or the synergistic microbes interact with signaling pathways (MAMPs) of the plant to elevate the production of its immune response. However, if pathogen could interact by using MAMPs, the immune output will be higher and will restrict the colonial establishment of pathogens. Pathogens that live in host tissues use hemibiotrophs and necrotrophs mode of life (Table 5.3). Some chemicals of the plant tissues inhibit the microbial association either biotrophs (salicylic acid) or necrotrophs (jasmonic acid) type and also the reactive $\mathrm{O}_{2}$ species may have an inhibitory effect on the pathogens (Lehmann et al. 2015). Plants use jasmonic acid, methyl jasmonate, ethylene, flavonoid, 12-oxo-phytodienoic acid, and salicylic acid-mediated signals for quenching pathogens on its surface (Table 5.4). Recently, pathogens with biotrophy-necrotrophy switch have been identified in fungi such as Colletotrichum sp, Phytophthora capsici, Moniliophthora roreri, and Macrophomina phaseolina in which pathogen evokes a differential response of growth in host tissues (Chowdhury et al. 2015). Some important research in the mode of immune evoke by the pathogen has been listed in Tables 5.3 and 5.4.

Phyllosphere region is usually colonized by a variety of microorganisms. Naturally, leaf epidermises are always contacted to external and internal environments and are enriched with a diverse group of bacteria, yeast, fungi, and viruses. The cuticle layer of the leaf surface plays a significant role during the contact with leaf

Table 5.3 Mode of life cycle of pathogen established against plant immunity

\begin{tabular}{|c|c|c|c|}
\hline Organism & Life cycle & Host & References \\
\hline Fusarium graminearum & Hemibiotrophic & Wheat & Ding et al. (2011) \\
\hline $\begin{array}{l}\text { Colletotrichum } \\
\text { graminicola }\end{array}$ & $\begin{array}{l}\text { Biotrophic and } \\
\text { necrotrophic }\end{array}$ & Maize & Vargas et al. (2012) \\
\hline Septoria tritici & Hemibiotrophic & Wheat & Yang et al. (2013) \\
\hline Phytophthora capsici & Hemibiotrophic & Tomato & Jupe et al. (2013) \\
\hline Colletotrichum sp. & Hemibiotrophic & Plants & Gan et al (2013) \\
\hline Moniliophthora roreri & $\begin{array}{l}\text { Hemibiotrophic and } \\
\text { necrotrophic }\end{array}$ & Cacao & Meinhardt et al. (2014) \\
\hline Fusarium verticillioides & Biotrophic & Maize & Lanubile et al. (2014) \\
\hline Botrytis $\mathrm{sp}$ & Necrotrophic & Plants & Van Kan et al. (2014) \\
\hline Botrytis fabae & Necrotrophic & Faba bean & El-Komy (2014) \\
\hline Sclerotinia sclerotiorum & $\begin{array}{l}\text { Biotrophic, } \\
\text { hemibiotrophic, and } \\
\text { necrotrophic }\end{array}$ & Plants & Kabbage et al. (2015) \\
\hline Zymoseptoria tritici & Hemibiotrophic & Wheat & Rudd et al. (2015) \\
\hline Phytophthora infestans & Hemibiotrophic & Tomato & Zuluaga et al. (2016) \\
\hline Rhizoctonia solani & Necrotrophic & Wheat & Foley et al. (2016) \\
\hline
\end{tabular}

Note "Hemibiotrophs" - an organism that is parasitic in living tissue for some time and then continues to live in dead tissue. "Necrotrophs" - can kill the host cells and feed on the contents 
Table 5.4 Signaling pathway inhibits pathogenic microbes in phyllosphere

\begin{tabular}{l|l|l|l}
\hline Molecules/signals & Pathogen & Host & References \\
\hline Flavonoid pathway & Bacterial pathogens & $\begin{array}{l}\text { Melampsora } \\
\text { medusae }\end{array}$ & Miranda et al. (2007) \\
\hline $\begin{array}{l}\text { Jasmonic acid, } \\
\text { ethylene, and the } \\
\text { flavonoid }\end{array}$ & $\begin{array}{l}\text { Phymatotrichopsis } \\
\text { omnivora }\end{array}$ & Medicago truncatula & $\begin{array}{l}\text { Uppalapati et al. } \\
(2009)\end{array}$ \\
\hline $\begin{array}{l}\text { Methyl jasmonate } \\
\text { and ethylene }\end{array}$ & $\begin{array}{l}\text { Macrophomina } \\
\text { phaseolina }\end{array}$ & Medicago truncatula & Gaige et al. (2010) \\
\hline $\begin{array}{l}\text { Jasmonic acid and } \\
\text { ethylene }\end{array}$ & $\begin{array}{l}\text { Fusarium } \\
\text { graminearum }\end{array}$ & Wheat & Sun et al. (2010) \\
\hline $\begin{array}{l}\text { Jasmonate and } \\
\text { ethylene }\end{array}$ & Fusarium sp & Wheat & $\begin{array}{l}\text { Gottwald et al. } \\
(2012)\end{array}$ \\
\hline $\begin{array}{l}\text { Ethylene and } \\
\text { jasmonate }\end{array}$ & Pythium ultimum \\
\hline $\begin{array}{l}\text { Methyl jasmonate, } \\
\text { 12-oxo-phytodienoic } \\
\text { acid, salicylic acid, } \\
\text { and flavonol }\end{array}$ & $\begin{array}{l}\text { Fusarium oxysporum } \\
\text { f.sp. lycopersici }\end{array}$ & Tomato & Shin et al. (2014) \\
\hline
\end{tabular}

microbiota (Vacher et al. 2016). Though some group of microorganism may not multiply after it reaches on the surface, many continue to survive and multiply, until they can attain maximum number (Schönherr 2006; Innerebner et al. 2011; Pusey et al. 2011). To multiply, microorganisms require carbon, nitrogen, inorganic, and organic energy sources. However, in the absence of such nutrients, phyllosphere is still usually colonized by a large number of bacteria (105-107 CFU/g of the leaf) in the presence of high relative humidity and free water at suitable environmental conditions (Schönherr 2006; Baldwin et al. 2017). This is due to the release of nutrients or leaf exudates which adequately supported the microbial growth. There are varieties of molecules leached from the plant leaves such as sugar, amino acids, organic acids, minerals, etc. (Beattie 2011; Remus-Emsermann et al. 2011; Meiners et al. 2017). These leaching materials may differ with plant species and the environmental condition (Beattie 2011; Remus-Emsermann et al. 2011; Mendes et al. 2013).

Nutrients such as sugar photosynthates from the leaf interior may be diffused through the cuticle reached the outer surface (Schreiber 2005), and are chiefly used by phyllosphere bacteria. Moreover, water droplets on a leaf surface facilitate the outward diffusion of these sugars (Van der Wal et al. 2013). Both non-pathogenic and pathogenic microorganisms establish colonization on the leaf surface. To survive and thrive, epiphytic microbes have several adaptive properties such as the production of antibiotics, extracellular polymeric substances (EPS), biosurfactant for increasing cuticle permeability, and availability of nutrients volatile organic compounds (VOCs) to the leaf surface. However, in order to avoid the entry of pathogens, plants develop defense reactions. The preliminary defense is activated by recognition of the chemical compounds released during the contact with microbes (Boller and Felix 
2009). Pathogen-induced molecular patterns (PAMPs)-triggered immunity (PTI) is a broad spectrum of defenses against the pathogen invades. However, effectors produced by the pathogens often interfere with PTI activation and are recognized by specific proteins, which stimulate effector-triggered immunity (ETI) that induces a hypersensitive response (Craig et al. 2009).

\subsection{How to Study Phyllosphere Microbiome?}

The diversity and community structure of phyllosphere microbes have been intensely studied by culture-independent methods. However, this approach failed to isolate and identify the complete microbiome of the environment. Therefore, scientist used the culture-independent mass sequencing methods which have been carried out by highthroughput molecular methods, especially PCR-amplified DNA-level conserved taxonomic markers such as 16S rRNA, 18S rRNA, and internal transcribed spacer (ITS) sequences-based metagenome of phyllosphere total microbiome (Mao et al. 2012; Santhanam et al. 2014; Williams and Marco 2014; Jo et al. 2015; Copeland et al. 2015) (Fig. 5.4). The first-generation molecular techniques such as Sanger sequencing, denaturing gradient gel electrophoresis (DGGE), and terminal restriction fragment length polymorphism have been used to describe the community structure variation in plant phenotype, and geographical location (Hunter et al. 2010; Vokou et al. 2012; Izhaki et al. 2013). Those techniques are low throughput and highly expensive that can be used to detect the superficial microbial community of the environment (Rastogi and Sani 2011).

Advancements in molecular techniques, next-generation DNA sequencing is the potent method that significantly reduces the costs and allows to perform hundreds of samples in a single attempt. These techniques open up new windows of omics, specifically "environmental omics." The 454 pyrosequencing is the first to be widely executed to study in microbial community analysis. This method comprises rRNA or ITS amplicon sequencing, whole-genome sequencing, shotgun metagenomics, and transcriptional profiling (Delmotte et al. 2009; Rastogi et al. 2012). Recently, Illumina platform has been performed better and allows ultra-high-throughput sequencing of microbial communities with high-quality reads (Degnan and Ochman 2012). Proteogenomic is another method used for the microbial community structure analysis (Delmotte et al. 2009), a combination of genomics and proteomics to a great extent makes easy the structural and functional differences of microbiota in the phyllosphere environments. Through those methods, microbial diversity of several host plants such as Arabidopsis, Apple tree, Beech, grapevine, oak, poplar, Prunus, rice, soybean, spinach, tomato wheat, etc. was documented. The metadata of the metagenomic studies helps to understand the growth behavior, colonization ability, genus-level community structure formation (or) association, low and high index of diversity, and the host genotype effects on the self-defense as well as the cell wall integrity have been reported. 


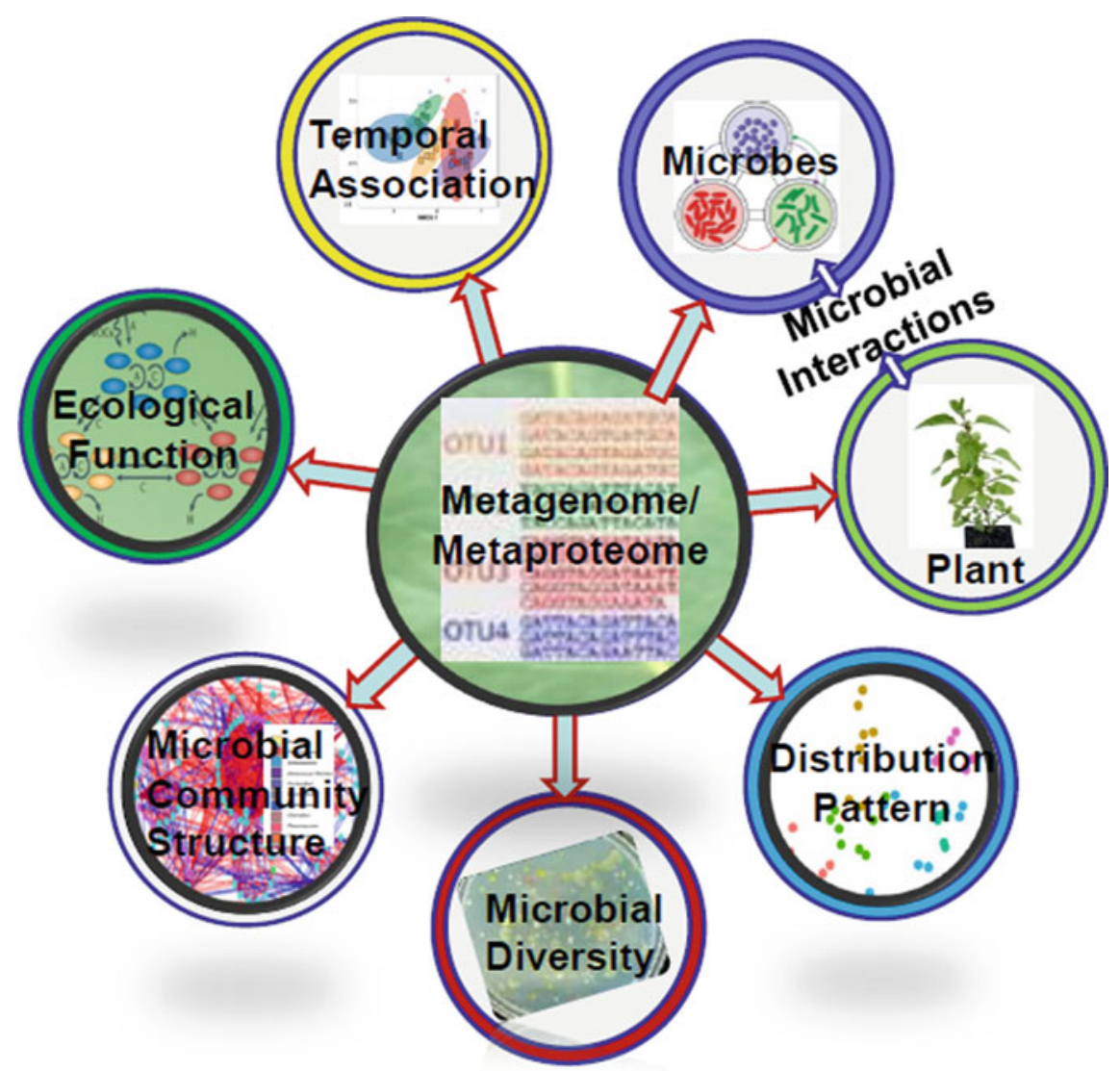

Fig. 5.4 Scope of metagenome in phyllosphere microbes and their functions

Whole microbiome analysis by environmental sequencing is popular today to explain the plant's phyllosphere containing complex microbial communities. There are many methods for mapping the diversity of microbiome which could associate with any of the living and nonliving objects. Also, the environmental sequencing approach determines the whole microbiome of the plant and it illustrates the significant association of microbes on its host under controlled conditions. Recently, studies revealed that genome-wide association (GWA) is the best method which shows potential merits for identifying the microbial communities associated with different kinds of host-microbe interactions. The high-throughput environmental sequencing approach has guided to the discoverer to find the complex microbial ecosystem of leaves. Using this strategy, many studies revealed the microbial association in the phyllosphere of different plants such as mountain shrubs (Ruiz-Pérez et al. 2016), seagrass (Fahimipour et al. 2017), subarctic grass (Uroz et al. 2016), and equatorial forest canopies (Lambais et al. 2006). The studies revealed that plant 
leaves are colonized by a huge and diverse group of microorganisms, including bacteria, fungi, and viruses (Rastogi et al. 2013; Morella et al. 2018; Sapp et al. 2018; Beilsmith et al. 2019). High-throughput molecular methods or culture-independent molecular techniques have interpreted the phyllosphere microbial community today (Table 5.5). Through this technique, Actinobacteria, Bacteroidetes, Firmicutes, and Proteobacteria are common microbiome of plant leaves (Bulgarelli et al. 2013), and it suggests that Pseudomonas, Sphingomonas, Methylobacterium, Bacillus, Massilia, Arthrobacter, and Pantoea are predominant genera consistently firm in the phyllosphere. Findings of the studies disclose the variation of microbial community structure mainly based on the genotypic nature of the plant species and also its geographical location. For example, Finkel et al. (2011) observed similar bacterial communities from the different species of Tamarix (T. aphylla, T. nilotica, and $T$. tetragina) grown in the same geographical location; however, differences in community structure of microbiota have been strongly related to its geographical distances (Rastogi et al. 2012).

Moreover, the high-throughput studies revealed the special functions/metabolism of the microbes associated with leaf surfaces, specifically carbohydrate transport, leaf litter decomposition, light-driven ATP pumps, methanol metabolism, C1 metabolism (Ottesen et al. 2013; Shade et al. 2013), and the effect of ecological factors such as climate change, temperature, seasonal variation, sporadic contact to soil, and/or anthropogenic activities such as the use of agricultural chemicals and pesticides (Ikeda et al. 2011; Shade et al. 2013; Karlsson et al. 2014; Copeland et al. 2015; Glenn et al. 2015). To attain better perceptive of the phyllosphere ecosystem and understand the functional relationship among plants, microbiota, and environment, metaproteome and metagenomics have been used (Rastogi et al. 2012; Bálint et al. 2013; Dees et al. 2015).

\subsection{Impact of Phyllosphere Microbiome on Ecosystem}

Phyllosphere microflora significantly influences the ecological relationship of the plants. The phyllosphere usually has bacteria, fungi, lichens, algae, and viruses that have actively participated in the adaptation, growth, resistance, and infection of the plant host (Walker et al. 2017; Verma et al. 2017; Yadav et al. 2018a). The phyllosphere microbiota has not been completely studied with their ecological significance, specifically plant and ecosystem level (Remus-Emsermann and Schlechter 2018). From seed germination to plant reproduction, studies have revealed how the phyllosphere microbiome affects the leaf functions and longevity, seed mass, apical growth, flowering, and fruit development (Jones and Dangl 2006; Sawinski et al. 2013; Kembel et al. 2014); however, the net interplay of the phyllosphere ecosystem in and around the plant is scanty. Recent scientific advancements that simplify the phyllosphere microbial life become understandable. The high-throughput genomics, such as environmental genomics and metagenomics, have greatly expanded our perceptive 
Table 5.5 Studies on high-throughput molecular approaches to phyllosphere communities

\begin{tabular}{|c|c|c|c|}
\hline Method & Plant & Study & References \\
\hline \multirow[t]{9}{*}{$\begin{array}{l}\text { 16S rRNA gene } \\
\text { pyrosequencing }\end{array}$} & $\begin{array}{l}\text { Soybean, clover, } \\
\text { Arabidopsis }\end{array}$ & $\begin{array}{l}\text { Epiphytic fitness of } \\
\text { Sphingomonas and } \\
\text { Methylobacterium }\end{array}$ & $\begin{array}{l}\text { Delmotte et al. } \\
\text { (2009) }\end{array}$ \\
\hline & $\begin{array}{l}\text { Pine and other } \\
\text { trees }\end{array}$ & $\begin{array}{l}\text { Phyllosphere bacteria } \\
\text { community composition }\end{array}$ & $\begin{array}{l}\text { Redford et al. } \\
\text { (2010) }\end{array}$ \\
\hline & Spinach & $\begin{array}{l}\text { Genus-level communities } \\
\text { of Proteobacteria and } \\
\text { Firmicutes-associated } \\
\text { spinach leaves }\end{array}$ & $\begin{array}{l}\text { Lopez-Velasco et al. } \\
\text { (2011) }\end{array}$ \\
\hline & Grape & $\begin{array}{l}\text { Bacterial communities on } \\
\text { the surface of leaves and } \\
\text { berries from grapevine }\end{array}$ & $\begin{array}{l}\text { Leveau and Tech } \\
\text { (2011) }\end{array}$ \\
\hline & Lettuce & $\begin{array}{l}\text { A "core" community } \\
\text { composed of } \\
\text { Pseudomonas, Bacillus, } \\
\text { Massilia, Arthrobacter, and } \\
\text { Pantoea found in lettuce } \\
\text { foliage }\end{array}$ & Rastogi et al. (2012) \\
\hline & Lettuce & $\begin{array}{l}\text { Variation in phyllosphere } \\
\text { microbiota composition. } \\
\text { Effect of } E \text {. coli O157:H7 } \\
\text { inoculation on microbiota } \\
\text { composition }\end{array}$ & $\begin{array}{l}\text { Williams et al. } \\
\text { (2013) }\end{array}$ \\
\hline & Rice & $\begin{array}{l}\text { Metagenomic analysis of } \\
\text { rice phyllospheric bacterial } \\
\text { communities in relation to } \\
\text { blast disease }\end{array}$ & $\begin{array}{l}\text { Prasad Sahu and } \\
\text { Kumar (2015) }\end{array}$ \\
\hline & $\begin{array}{l}\text { Common bean, } \\
\text { soybean, and } \\
\text { canola }\end{array}$ & $\begin{array}{l}\text { Seasonal community } \\
\text { succession of the } \\
\text { phyllosphere microbiome }\end{array}$ & $\begin{array}{l}\text { Copeland et al. } \\
\text { (2015) }\end{array}$ \\
\hline & Espeletia species & $\begin{array}{l}\text { Microbial and functional } \\
\text { diversity within the } \\
\text { phyllosphere. }\end{array}$ & $\begin{array}{l}\text { Ruiz-Pérez et al. } \\
\text { (2016) }\end{array}$ \\
\hline \multirow[t]{4}{*}{$\begin{array}{l}\text { 16/18S rRNA gene } \\
\text { pyrosequencing }\end{array}$} & Oak & $\begin{array}{l}\text { Fungal communities in the } \\
\text { oak phyllosphere }\end{array}$ & $\begin{array}{l}\text { Jumpponen and } \\
\text { Jones (2009) }\end{array}$ \\
\hline & $\begin{array}{l}\text { Tamarix aphylla, } \\
\text { T nilotica, } \\
\text { T. tetragina }\end{array}$ & $\begin{array}{l}\text { Geographical location is a } \\
\text { major determinant of } \\
\text { phyllosphere bacterial } \\
\text { communities }\end{array}$ & Finkel et al. (2011) \\
\hline & Beech & $\begin{array}{l}\text { Plant genotype-based } \\
\text { fungal communities on leaf } \\
\text { surfaces }\end{array}$ & Cordier et al. (2012) \\
\hline & Balsam poplar & $\begin{array}{l}\text { Plant species-based fungal } \\
\text { community composition }\end{array}$ & Balint et al. (2013) \\
\hline
\end{tabular}


Table 5.5 (continued)

\begin{tabular}{|c|c|c|c|}
\hline \multirow[t]{2}{*}{ Method } & Plant & Study & References \\
\hline & Pine & $\begin{array}{l}\text { Rapid microbial } \\
\text { community changes during } \\
\text { initial stages of pine litter } \\
\text { decomposition }\end{array}$ & $\begin{array}{l}\text { Gołębiewski et al. } \\
\text { (2019) }\end{array}$ \\
\hline \multirow[t]{3}{*}{ Metaproteogenomics } & $\begin{array}{l}\text { Soybean, clover, } \\
\text { Arabidopsis }\end{array}$ & $\begin{array}{l}\text { Metabolic adaptations } \\
\text { contribute to the epiphytic } \\
\text { fitness of Sphingomonas } \\
\text { and Methylobacterium }\end{array}$ & $\begin{array}{l}\text { Delmotte et al. } \\
\text { (2009) }\end{array}$ \\
\hline & Rice & $\begin{array}{l}\text { Several methylotrophic } \\
\text { enzymes and their role in } \\
\text { the carbon cycle by } \\
\text { Methylobacterium }\end{array}$ & Knief et al. (2012) \\
\hline & Maize & $\begin{array}{l}\text { Functional genes that } \\
\text { distinguish maize } \\
\text { phyllosphere metagenomes } \\
\text { in drought and } \\
\text { well-watered conditions }\end{array}$ & Methé et al. (2017) \\
\hline
\end{tabular}

and understanding on the functional life of phyllosphere microbial communities in plant-environment and the impact on the ecosystem.

Environmental factors are drastically influencing the microbiome changes on phyllosphere. This is common to epiphytic microorganisms, exposed with heavy stress during the season cycle, the day/night cycle, and the growth, age, and anatomical dynamics of the plant. For instance, at drought condition, the epiphytic microbial community was notably increased on Holm oak (Rico et al. 2014). Similarly, at hot condition, bacterial endophytic communities are altered in lower leaves of paddy, but not in the epiphytes (Ren et al. 2014). However, the epiphytic fungal community responded well in worming seasons (Coince et al. 2014; Bálint et al. 2015). Besides, an increase of $\mathrm{CO}_{2}$ at the phyllosphere region never affects the bacterial abundance (Ren et al. 2014; Vacher et al. 2016), except a few fungal genera.

Microbes have flexible metabolic adaptations, which helps them to survive in the phyllosphere microenvironment. During the metabolic functions, the plant releases carbohydrates, polyols, amino acids, amines, isoprenoids, halogenated compounds, or alcohols, as well as water and salts, which are the available nutrients for epiphytic microorganisms (Trouvelot et al. 2014). However, leaf surface commonly exhibits desolate properties such as saline or alkaline $\mathrm{pH}$ which generates stress in phyllosphere microbes (Finkel et al. 2012). Several alphaproteobacteria express PhyR-based stress regulation and colonization on leaf surface (Iguchi et al. 2013). Additionally, they develop multiple mode adaptation to survive in phyllosphere such as tolerance, antimicrobial, and immunity compounds against a microbial competitor (Trouvelot et al. 2014), synthesis of extracellular polysaccharides, and also synthesize phytohormonal compounds. 
Besides, biotic and abiotic factors induce molecular level regulations in plants to synthesize a diverse range of phytohormones. Generally, the gaseous ethylene, jasmonate, methyl jasmonate, salicylate, and methylsalicylate are induced by bacterial pathogens (Bodenhausen et al. 2014; Horton et al. 2014). For example, many plant defense mechanisms are induced by the interaction of the biotic component of the ecosystem through signals like volatile and nonvolatile chemicals, and microbes can degrade such chemicals resulting in reduced activity (Mason et al. 2014).

The phyllosphere microbiome acts as a vital role for leaf surface environment and their surrounding ecosystem functions (Ortega et al. 2016). Phyllosphere microbes have interacted with their environment through their metabolic functions (Fig. 5.5). In general, plants release a variety of volatile organic compounds (VOCs) and its precursors on the surface of leaves (Schäfer et al. 2010), and it could regulate the microorganisms in response with the environment. Plants are the major VOCs emitter of the biosphere ( $>1000 \mathrm{Tg} / \mathrm{year})$ and can release compounds such as terpenes, monoterpenes, flavones, methanol, methane, and halogenated methane ( $\mathrm{C} 1$ compounds). The epiphytic microbes on the surface of the plant, as well as the airborne bacteria, effectively consumed the emitted VOCs through bacterial metabolism (Junker and Tholl 2013), and this effects of climate change would impact the diversity, species richness, and abundance in the phyllosphere community, and its capability on filtering of plant-emitted volatile substances.

Methane $\left(\mathrm{CH}_{4}\right)$ is the most important greenhouse gas $(\sim 1.8 \mathrm{ppm})$, and it has been detected from the leaves, roots, and stems and is released to the atmosphere (Keppler et al. 2006). Phyllosphere microbes especially methanogens use the plant-emitted methane along with leaf exudates (Lenhart et al. 2015; Bringel and Couée 2015). Phyllospheric microbes are often rich in methylotrophic bacteria and can utilize the plant-emitted C1 compounds such as methanol, formaldehyde, and chloromethane

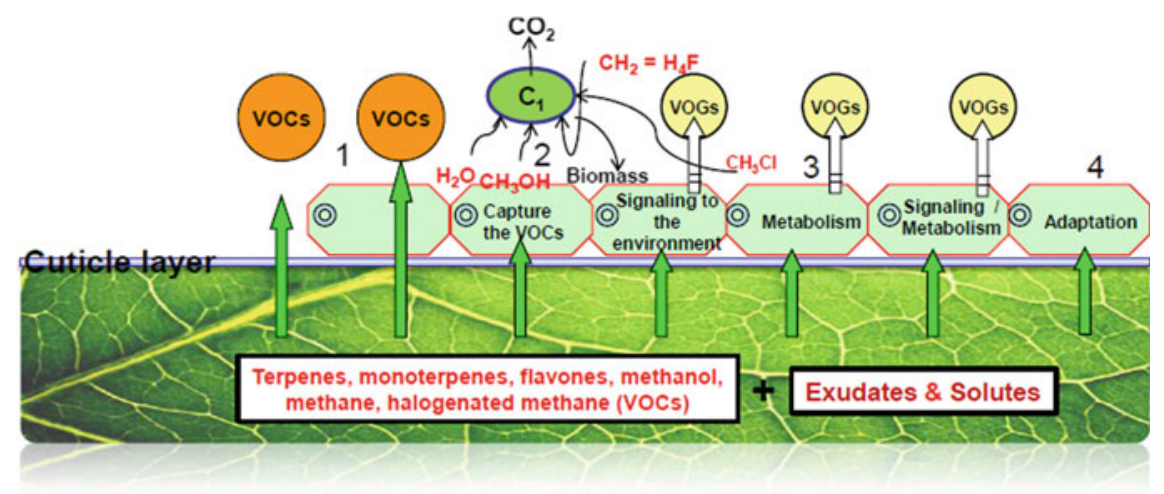

Fig. 5.5 Environmental impact of phyllosphere microbes. Utilization of plant emitting volatile organic compound (VOCs) and $\mathrm{C} 1$ compounds by phyllosphere microbes. (1) Free diffusion of VOCs to the atmosphere; (2) Capturing the VOCs by the surface microbes, act as filters; (3) Through specialized metabolic activities microbes metabolize the VOCs; (4) Adaptive response of microbes in the specialized environment. VOGs_-Volatile organic gases 
(Knief et al. 2012; Jo et al. 2015). Studies proved that the C1 metabolic epiphytic bacteria such as Methylobacterium extorquens, Methylobacterium radiotolerans, and Methylocystis use methanol and acetate as their carbon and energy source at the phyllosphere (Belova et al. 2011; Verginer et al. 2010; Iguchi et al. 2013; Jo et al. 2015; Iguchi et al. 2015; Krishnamoorthy et al. 2018). The Methylobacterium extorquens contains the methanol-dehydrogenase-like protein XoxF which is expressed during the colonization on Arabidopsis thaliana (Schmidt et al. 2010). Besides, chloromethane metabolism (cmu pathway) in methylotrophs has been identified from the surface leaves of $A$. thaliana harbor (Nadalig et al. 2011; Krishnamoorthy et al. 2018). Table 5.6 shows the various phyllosphere methanogenic bacteria and its metabolism.

Chloromethane $\left(\mathrm{CH}_{3} \mathrm{Cl}\right)$ is one of the abundant chlorinated organic compounds in the atmosphere (currently $\sim 550 \mathrm{ppt}$ ) and is to be responsible for the depletion of stratospheric ozone over 16\% (World Meteorological Organization 2014). The fluorescence-based bacterial bioreporter study reported that phyllosphere microbes, M. extorquens CM4 (Roselli et al. 2013) and Hyphomicrobium sp. (Nadalig et al. 2011), having the genes for chloromethane utilization (сти), and also volatile dimethylsulphide (DMS) and dimethylsulfoniopropionate (DMSP), considered as global climate regulator (Schäfer et al. 2010; Nevitt 2011). In the biosphere, a small number of plants like salt marsh grasses Spartina and sugarcanes (Saccharum sp.) are reported as producers of DMSP. Microbes that are associated with these plants have adaptive metabolism by which it transforms or metabolizes the DMS and DMSP (Ansede et al. 2001). Hence, the phyllosphere microbes are the major source of carbon and sulfur biogeochemical cycles, in the ecosystem and climate regulation through their active filtration or utilization of plant-related volatile compounds (DeLeon-Rodriguez et al. 2013; Šantl-Temkiv et al. 2013).

Microbial populations reside at phyllosphere as epiphytes or as endophytes, and have close contact with the rhizosphere. A microbe can be established as an epiphytic and endophytic association has the metabolic plasticity required for them to thrive. Many experimental evidences suggested that microorganisms commonly associated with plants maybe vital for nutrient accessibility and decomposition of biomass (Bernal et al. 2006; Ramírez Gómez 2011; Lizarazo-Medina and GómezVásquez 2015). The functional ecology of the plant influences the composition and interaction of the phyllosphere microbes (Bodenhausen et al. 2013; Ruiz-Pérez et al. 2016). Many of the phyllosphere microbial communities share the common metabolic properties of the soil microbes. For example, the major phyllosphere bacterial communities such as Bacillus, Burkholderia, Methylobacterium, Pseudomonas, Sphingomonas, and Xanthomonas are the soil inhabitant, which have carbohydrate metabolizing genes involved in utilization of starch, hemicellulose, pectin, and cellulose, rich in humus materials (Rawat et al. 2012; Bodenhausen et al. 2013; Bulgarelli et al. 2013). The nitrogen metabolism such as ammonification, denitrification, and anammox, and the degradation of aromatic compounds are also reported in foliar microbes (Usubillaga et al. 2001; Rawat et al. 2012; Ruiz-Pérez et al. 2016).

Tropospheric microbes (aerosols) play a vital function in global carbon cycles and also metabolize the organic compounds. Some airborne Gammaproteobacteria have 
Table 5.6 Studies on Phyllospheric methylotrophic metabolism

\begin{tabular}{|c|c|c|c|}
\hline Epiphyte & Host plant & Function & References \\
\hline $\begin{array}{l}\text { Methanotrophs and } \\
\text { Methylobacteria }\end{array}$ & $\begin{array}{l}\text { Linden, pine and blue } \\
\text { spruce lilac, maple, } \\
\text { and apple }\end{array}$ & $\begin{array}{l}\text { Diversity of } \\
\text { Methanotrophs in } \\
\text { woody plant tissues } \\
\text { within the winter } \\
\text { period }\end{array}$ & $\begin{array}{l}\text { Doronina et al. } \\
\text { (2004) }\end{array}$ \\
\hline $\begin{array}{l}\text { Methylobacterium } \\
\text { extorquens }\end{array}$ & Medicago truncatula & $\begin{array}{l}\text { Methylotrophic } \\
\text { metabolism is } \\
\text { advantageous for } \\
\text { colonization under } \\
\text { competitive } \\
\text { conditions }\end{array}$ & Sy et al. (2005) \\
\hline $\begin{array}{l}\text { Methylobacterium } \\
\text { extorquens }\end{array}$ & - & $\begin{array}{l}\text { A proteomic study of } \\
\text { Methylobacterium } \\
\text { extorquens reveals a } \\
\text { response regulator } \\
\text { essential for } \\
\text { epiphytic growth }\end{array}$ & Gourion et al. (2006) \\
\hline $\begin{array}{l}\text { Methylobacterium } \\
\text { extorquens AM1 }\end{array}$ & - & $\begin{array}{l}\text { PhyR is involved in } \\
\text { the general stress } \\
\text { response }\end{array}$ & Gourion et al. (2008) \\
\hline $\begin{array}{l}\text { Methylocystis heyeri } \\
\text { H2(T) and } M . \\
\text { echinoides } \\
\text { IMET10491(T) }\end{array}$ & Peat & $\begin{array}{l}\text { Acetate utilization } \\
\text { metabolism as a } \\
\text { survival strategy }\end{array}$ & Belova et al. (2011) \\
\hline $\begin{array}{l}\text { Methylobacterium } \\
\text { extorquens DSM } \\
21961\end{array}$ & Strawberry & $\begin{array}{l}\text { Monitoring the plant } \\
\text { epiphyte } \\
\text { Methylobacterium } \\
\text { extorquens DSM } \\
21961\end{array}$ & Verginer et al. (2010) \\
\hline $\begin{array}{l}\text { Methylobacterium } \\
\text { extorquens }\end{array}$ & $\begin{array}{l}\text { Arabidopsis thaliana } \\
\text { or Medicago } \\
\text { truncatula }\end{array}$ & $\begin{array}{l}\text { The influence of the } \\
\text { factor site, host plant } \\
\text { species, time and the } \\
\text { presence of other } \\
\text { phyllosphere bacteria } \\
\text { on Methylobacterium } \\
\text { community } \\
\text { composition and } \\
\text { population size }\end{array}$ & Knief et al. (2010) \\
\hline Candida boidinii & Arabidopsis thaliana & $\begin{array}{l}\text { Yeast methylotrophy } \\
\text { and autophagy in a } \\
\text { methanol-oscillating } \\
\text { environment on } \\
\text { growing leaves }\end{array}$ & $\begin{array}{l}\text { Kawaguchi et al. } \\
\text { (2011) }\end{array}$ \\
\hline
\end{tabular}


Table 5.6 (continued)

\begin{tabular}{|c|c|c|c|}
\hline Epiphyte & Host plant & Function & References \\
\hline $\begin{array}{l}\text { Methylobacterium } \\
\text { sp. (NC4), (NC28) }\end{array}$ & $\begin{array}{l}\text { Sugarcane, pigeon } \\
\text { pea, mustard, potato, } \\
\text { and radish }\end{array}$ & $\begin{array}{l}\text { Epiphytic } \\
\text { pink-pigmented } \\
\text { methylotrophic } \\
\text { bacteria enhance } \\
\text { germination and } \\
\text { seedling growth of } \\
\text { wheat (Triticum } \\
\text { aestivum) by } \\
\text { producing } \\
\text { phytohormone }\end{array}$ & Meena et al. (2012) \\
\hline $\begin{array}{l}\text { Methylobacterium } \\
\text { sp. strain OR01 }\end{array}$ & Perilla plants & $\begin{array}{l}\text { Dominant } \\
\text { colonization and } \\
\text { inheritance of } \\
\text { Methylobacterium } \\
\text { sp. }\end{array}$ & Mizuno et al. (2013) \\
\hline $\begin{array}{l}\text { Methylosinus sp. } \\
\text { B4S }\end{array}$ & - & $\begin{array}{l}\text { Stress resistance and } \\
\mathrm{C} 1 \text { metabolism } \\
\text { involved in plant } \\
\text { colonization of a } \\
\text { methanotroph Arch }\end{array}$ & Iguchi et al. (2013) \\
\hline $\begin{array}{l}\text { Methylobacterium } \\
\text { oryzae }\end{array}$ & Rice & $\begin{array}{l}\text { plant-probiotic } \\
\text { methylotroph in the } \\
\text { phyllosphere }\end{array}$ & Kwak et al. (2014) \\
\hline $\begin{array}{l}\text { Methylobacterium } \\
\text { radiotolerans } \\
\text { VRI8-A4 }\end{array}$ & Groundnut & $\begin{array}{l}\text { Diversity of } \\
\text { culturable } \\
\text { methylotrophic } \\
\text { bacteria in different } \\
\text { genotypes of } \\
\text { groundnut and their } \\
\text { potential for plant } \\
\text { growth promotion }\end{array}$ & $\begin{array}{l}\text { Krishnamoorthy } \\
\text { et al. (2018) }\end{array}$ \\
\hline
\end{tabular}

ice nucleation-active (INA) property and contains specific gene (ina) via deposition of cloud droplets (Hill et al. 2014) on the leaf surface and mineralize the carbon compounds (Vaiitilingom et al. 2013). Reports confirmed the relationship of INA bacteria and phyllosphere microbiota, combined activities of both phyllosphere microbiota and cloud microbiota actively participating carbon cycle, and strong support for climate regulation (Bringel and Couée 2015). The above information suggested that the phyllosphere microbiome not only supports the health of its host but is also beneficial to the environment, specifically it regulates plant-derived greenhouse and other gaseous pollutants. 


\subsection{Biotechnological Potential of Phyllosphere Microbiota}

The plant beneficial microbes are agriculturally important bioresources, and it can stimulate the plant growth and enhance plant nutrient uptake through solubilization and mobilization ( of $\mathrm{P}, \mathrm{K}$, and $\mathrm{Zn}$ ), nitrogen fixation, and siderophore production (microbes-mediated bio-fortification of Fe in different crops). Beneficial microbes can play an important role in increasing yields of the crop, remove contaminants, inhibit pathogens, and produce novel substances. The growth stimulation by beneficial microbes can be a consequence of biological nitrogen fixation, production of plant growth regulators such as IAA, gibberellic acids, and cytokines, and biocontrol of phytopathogens through the production of antibiotic, antifungal, or antibacterial, Fe-chelating compounds, induction of acquired host resistance, enhancing the bioavailability of minerals (Kour et al. 2019; Kumar et al. 2019b; Yadav et al. 2019a).

In this contest, the phyllosphere microbes may positively influence the growth of host plant and produce some antagonistic compound against pathogens. Phyllosphere endophytes with properties such as nitrogen fixation (Jones 1970; Freiberg 1998; Furnkranz et al. 2008), bioremediation of harmful chemicals/pollutants, and biocontrol agents against important foliar plant pathogens (Beattie and Lindow 1995; Balint-Kurti et al. 2010; De Marco et al. 2004) have been documented. Further, the microbiome of phyllosphere is a reflection of environmental conditions; they can contribute significantly to global food webs and nutrient linkages. Many beneficial microbes such as Achromobacter, Bacillus, Beijerinckia, Burkholderia, Flexibacterium, Methylobacterium, Micrococcus, Micromonospora, Nocardioides, Pantoea, Penicillium, Planomonospora, Pseudomonas, Streptomyces, and Xanthomonas have been reported from the phyllosphere environment of different crop plants (Verma et al. 2013a, b; Mukhtar et al. 2010; Meena et al. 2012; Dobrovol'skaya et al. 2017). However, compared with most other microbial habitats, the investigation of phyllosphere microbes is quite limited. Some of its important biotechnological potentials are listed below.

\subsubsection{Biocontrol Agents}

Biocontrol is the measure to control pathogens and disease-causing pest including nematodes weeds, insects, and mites by other beneficial microbes or harmless living materials. In nature, plant diseases are caused by bacterial pathogens which provide a substantial decline in the development of agricultural products. For sustainable agriculture, scientific approaches use the antagonistic properties of beneficial microbes against the harmful pathogens instead of using toxic harmful chemicals as biological control (Erwin and Ribeiro 1996; Sharma et al. 2012). Biological treatment is a desirable strategy for controlling plant diseases (You et al. 2015) and there are an increasing number of biocontrol agents (BCAs), such as Bacillus spp., Pseudomonas spp., Trichoderma spp., etc. being commercialized for various crops (Trabelsi and 
Mhamdi 2013; Cha et al. 2016). Most of them habitat either on phyllosphere or soil and can play a significant role in killing the number of plant pathogens on the surface of the leaves by competitive principle.

Pathogenic microbial interactions in phyllosphere decrease the fitness of plants, the productivity of crops, and question the safety of horticultural products for human consumption. Phyllosphere actinomycetes have been reported to inhibit the growth and colonization of plant pathogens (Lindow and Brandl 2003). For example, the endophytic isolate Gordonia sp. has been reported to produce imidazole-2-yl amino acids that have antifungal properties (Mikolasch et al. 2003) and an acidic polysaccharide called Gordon as the main component in biofilms, which is considered essential for pathogenicity against plant disease (Kondo et al. 2000). Various Streptomyces sp. including $\mathrm{S}$. griseus have been reported as producing various antifungal compounds such as 1-H-pyrrole-2-carboxylic acid (PCA), cycloheximide, and streptomycin which were successfully used to control fungal and bacterial diseases in plants (Leben and Keitt 1954; Nguyen et al. 2015). Wiwiek et al. (2017) studied the rice phyllosphere actinomycetes could be used as potential biocontrol agents against fungal leaf blast disease. Wang and Ma (2011) reported that exogenous actinomycete $\mathrm{XN}-1$ has the potential to act as an antagonistic agent in controlling the occurrence and development of cucumber leaf spot in the greenhouse. This also confirms that phyllosphere microorganisms play an important role in combating the infection of pathogens and have a promising future in developing biocontrol products. Table 5.7 shows the plant-associated bacteria and its biological activities.

Microbes with the production of compounds like indole acetic acid and N-acyl homoserine lactone (AHL) assist the bacteria to colonize on plant surface (Lindow and Brandl 2003). Sartori et al. (2015) studied the biocontrol potential of phyllosphere microorganisms from maize against Exserohi lumturcicum, the causal agent of leaf blight. Shrestha et al. (2016) investigated the prospects of biological control of rice-associated Bacillus against sheath blight and panicle blight of rice caused by Rhizoctonia solani and Burkholderia glumae, respectively. A variety of Bacillus isolates were observed to inhibit the sclerotial germination of the fungus, which could be attributed to the various antimicrobial secondary metabolites produced by the bacteria. Various gram-negative bacteria also show plant protection activity. For example, Pseudomonas graminis isolated from the apple phyllosphere showed control against fire blight caused by Erwinia amylovora (Mikiciński et al. 2016), Pseudomonas protegens CS1 from the lemon phyllosphere are used as a biocontrol against citrus canker (Michavila et al. 2017).

Further, microbial production of siderophores quenches the phytopathogens and protects the host plant from their infection (Scavino and Pedraza 2013; Ahmed and Holmström 2014; Harsonowati et al. 2017; Sabaté et al. 2018) as a biocontrol agent. For example, the siderophore produced by Pseudomonas syringae pv. syringae 22d/93 shows biocontrol activity against Pseudomonas syringae pv. glycinea 1a/96, a plant pathogen (Wensing et al. 2010). The siderophore pyochelin produced by the endophyte control rice blast is caused by Pyricularia oryzae (Harsonowati et al. 2017). Plant-associated Pseudomonas spp. has been employed efficiently as commercial biocontrol agents (Loper and Lindow 1987; Walsh et al. 2001). Cyanogenic 
Table 5.7 Plant-associated microbial compounds and bioactivity

\begin{tabular}{|c|c|c|c|}
\hline Compound & Source & Bioactivity & References \\
\hline $\begin{array}{l}\text { Blasticidin-S } \\
\text { (VIII): }\end{array}$ & $\begin{array}{l}\text { Streptomyces } \\
\text { griseochromogenes } \\
\text { I }\end{array}$ & $\begin{array}{l}\text { Control the rice blast caused } \\
\text { by Pyricularia oryzae }\end{array}$ & $\begin{array}{l}\text { Fukunaga } \\
\text { (1955) }\end{array}$ \\
\hline Kasugamycin (IX) & $\begin{array}{l}\text { Streptomyces } \\
\text { kasugaensis }\end{array}$ & $\begin{array}{l}\text { Rice blast caused by } \\
\text { Pyricularia oryzae, leaf spot } \\
\text { in sugar beet and celery by } \\
\text { Cercospora spp., and scab in } \\
\text { pears and apples caused by } \\
\text { Venturia spp. }\end{array}$ & $\begin{array}{l}\text { Umezawa et al. } \\
\text { (1965) }\end{array}$ \\
\hline Methoxyphenone & $\begin{array}{l}\text { Streptomyces } \\
\text { griseolus }\end{array}$ & Herbicides & Ito et al. (1974) \\
\hline AM-toxin & Alternaria mali & phytotoxin & $\begin{array}{l}\text { Park et al. } \\
\text { (1977) }\end{array}$ \\
\hline Milbemycin (XI): & $\begin{array}{l}\text { S. hygroscopicus } \\
\text { subsp. } \\
\text { aureolacrimosus }\end{array}$ & Insecticidal and acaricidal & $\begin{array}{l}\text { Mishima et al. } \\
\text { (1983) }\end{array}$ \\
\hline Diabroticin A & $\begin{array}{l}\text { Bacillus subtilis } \\
\text { and Bacillus cereus }\end{array}$ & Polar insecticide & $\begin{array}{l}\text { Stierle et al. } \\
(1990)\end{array}$ \\
\hline $\begin{array}{l}\text { Spinosad }(X) \text { : } \\
\text { spinosyn A and } \\
\text { spinosyn D }\end{array}$ & $\begin{array}{l}\text { Saccharopolyspora } \\
\text { spinosa }\end{array}$ & $\begin{array}{l}\text { Controls the caterpillar } \\
\text { (Helicoverpa zea Boddie, } \\
\text { Pieris rapae (L.), Keiferia } \\
\text { lycopersicella (Walsingham), } \\
\text { thrips (Ceratitis capitata (L.), } \\
\text { Thrips palmi (Karny)) and } \\
\text { beetles (Leptinotarsa } \\
\text { decemlineata (Say)) }\end{array}$ & $\begin{array}{l}\text { Mertz and Yao } \\
(1990)\end{array}$ \\
\hline AF-toxins & Alternaria fragariae & $\begin{array}{l}\text { Maculosin is a cyclic } \\
\text { dipeptide-phytotoxin }\end{array}$ & $\begin{array}{l}\text { Stierle et al. } \\
(1990), \text { Uneo } \\
(1990)\end{array}$ \\
\hline Maculosin (XVI) & Phoma lingam & Phytotoxin & $\begin{array}{l}\text { Stierle et al. } \\
(1990)\end{array}$ \\
\hline Efrapeptins & Tolypocladium spp. & Pesticide and insecticide & $\begin{array}{l}\text { Krasnoff and } \\
\text { Gupta (1991), } \\
\text { Krasnoff et al. } \\
\text { (1991) }\end{array}$ \\
\hline Abamectin & $\begin{array}{l}\text { Streptomyces } \\
\text { avermitilis }\end{array}$ & Insecticide and acaricide & $\begin{array}{l}\text { Jansson and } \\
\text { Dybas (1996) }\end{array}$ \\
\hline Nodulisporic acid & Nodulisporium sp. & Insecticidal activity & $\begin{array}{l}\text { Ondeyka, et al. } \\
(1997)\end{array}$ \\
\hline $\begin{array}{l}\text { Pyrizadocidin } \\
\text { (VII) }\end{array}$ & $\begin{array}{l}\text { Streptomyces } \\
\# 620061\end{array}$ & Herbicides & $\begin{array}{l}\text { Gerwick et al. } \\
\text { (1997) }\end{array}$ \\
\hline Syringomycin E: & $\begin{array}{l}\text { Pseudomonas } \\
\text { syringae ESC 10/11 }\end{array}$ & $\begin{array}{l}\text { Fungicide-citrus green mold } \\
\text { Penicillium digitatum }\end{array}$ & $\begin{array}{l}\text { Bull et al. } \\
\text { (1998) }\end{array}$ \\
\hline
\end{tabular}


Table 5.7 (continued)

\begin{tabular}{|c|c|c|c|}
\hline Compound & Source & Bioactivity & References \\
\hline Destruxin A and B & M. anisopliae & Insecticide & $\begin{array}{l}\text { Strasser et al. } \\
(2000)\end{array}$ \\
\hline Oosporein & $\begin{array}{l}\text { Beauveria } \\
\text { brongniartii }\end{array}$ & Insecticide & $\begin{array}{l}\text { Strasser et al. } \\
(2000)\end{array}$ \\
\hline $\begin{array}{l}\text { Beauvericin } \mathrm{A} \text { and } \\
\mathrm{B}\end{array}$ & $\begin{array}{l}\text { Beauveria bassiana } \\
\text { and Paecilomyces } \\
\text { spp }\end{array}$ & Hexadepsipeptide_-insecticide & $\begin{array}{l}\text { Lane et al. } \\
(2000)\end{array}$ \\
\hline Borrelidin & $\begin{array}{l}\text { Streptomyces } \\
\text { species- neau-D50 }\end{array}$ & $\begin{array}{l}\text { Antifungal activity against } \\
\text { Phytophthora sojae }\end{array}$ & $\begin{array}{l}\text { Worapong et al. } \\
\text { (2001) }\end{array}$ \\
\hline Bialaphos (V) & $\begin{array}{l}\text { Streptomyces } \\
\text { hygroscopicus and } \\
\text { Streptomyces } \\
\text { viridochromogenes }\end{array}$ & Herbicide_—weed control & $\begin{array}{l}\text { Tachibana } \\
(2003)\end{array}$ \\
\hline Tartrolone C & $\begin{array}{l}\text { Streptomyces sp. } \\
\text { CP1130 }\end{array}$ & Insecticidal macrodiolide & $\begin{array}{l}\text { Lewer et al. } \\
(2003)\end{array}$ \\
\hline Coronatine & $\begin{array}{l}\text { Pseudomonas } \\
\text { coronafacience }\end{array}$ & Insecticide-herbicide & $\begin{array}{l}\text { Block et al. } \\
(2005)\end{array}$ \\
\hline Macrolactin A: & Bacillus sp. sunhua & $\begin{array}{l}\text { Fungicide-Fusarium } \\
\text { oxysporum and Streptomyces } \\
\text { scabies }\end{array}$ & $\begin{array}{l}\text { Han et al. } \\
(2005)\end{array}$ \\
\hline Bt-Toxins & $\begin{array}{l}\text { Bacillus } \\
\text { thuringiensis }\end{array}$ & Bioinsecticides endotoxins & $\begin{array}{l}\text { Collier et al. } \\
(2005)\end{array}$ \\
\hline Tabtoxin & $\begin{array}{l}\text { Pseudomonas } \\
\text { syringae var. tabaci }\end{array}$ & Phytotoxic_-Herbicide & $\begin{array}{l}\text { Hoagland et al. } \\
\text { (2007) }\end{array}$ \\
\hline Phyllostictine A & Phyllosticta cirsii & Mycoherbicide & $\begin{array}{l}\text { Zonno et al. } \\
(2008)\end{array}$ \\
\hline $\begin{array}{l}\text { Cinnacidin } \\
\text { (XXII): }\end{array}$ & $\begin{array}{l}\text { Nectria sp. } \\
\text { DA60047 }\end{array}$ & Phytotoxic & $\begin{array}{l}\text { Irvine et al. } \\
(2008)\end{array}$ \\
\hline $\begin{array}{l}\text { Beauvericin A and } \\
\text { B }\end{array}$ & $\begin{array}{l}\text { Beauveria bassiana } \\
\text { and Paecilomyces } \\
\text { spp. }\end{array}$ & Hexadepsipeptide-insecticide & $\begin{array}{l}\text { Miller et al. } \\
\text { (2008) }\end{array}$ \\
\hline Herbimycin (VI) & $\begin{array}{l}\text { Streptomyces } \\
\text { hygroscopicus } \\
\text { AM3672 }\end{array}$ & $\begin{array}{l}\text { Benzaquinoid ansamycin } \\
\text { antibiotic with potential } \\
\text { herbicidal a }\end{array}$ & $\begin{array}{l}\text { Hahn et al. } \\
(2009)\end{array}$ \\
\hline Albucidin & $\begin{array}{l}\text { Streptomyces albus } \\
\text { subsp. chlorinus } \\
\text { NRRL B-24108 }\end{array}$ & Herbicides & $\begin{array}{l}\text { Hahn et al. } \\
(2009)\end{array}$ \\
\hline Zinniol & $\begin{array}{l}\text { Alternaria } \\
\text { cirsinoxia }\end{array}$ & $\begin{array}{l}\text { Phytotoxic to Cirsium arvense } \\
\text { L. }\end{array}$ & $\begin{array}{l}\text { Berestetskii } \\
\text { et al. (2010) }\end{array}$ \\
\hline $\begin{array}{l}\text { Ascaulitoxin } \\
\text { aglycone }\end{array}$ & Ascochyta caulina & Phytotoxin & $\begin{array}{l}\text { Duke et al. } \\
(2011)\end{array}$ \\
\hline $\begin{array}{l}\text { Antibiotic } 1233 \mathrm{~A} \\
\text { (XXIV) }\end{array}$ & $\begin{array}{l}\text { Cephalosporium } \\
\text { sp., Fusarium sp., }\end{array}$ & Phytotoxin & $\begin{array}{l}\text { Duke and } \\
\text { Dayan (2011) }\end{array}$ \\
\hline
\end{tabular}


Table 5.7 (continued)

\begin{tabular}{l|l|l|l}
\hline Compound & Source & Bioactivity & References \\
\hline AK-toxin (XV): & $\begin{array}{l}\text { Alternaria } \\
\text { kikuchiana }\end{array}$ & Phytotoxin & Saxena (2014) \\
\hline $\begin{array}{l}\text { Bipolaroxin } \\
\text { XVIII) }\end{array}$ & $\begin{array}{l}\text { Bipolaris } \\
\text { cynodontis }\end{array}$ & $\begin{array}{l}\text { Phytotoxic to Cynodon } \\
\text { dactylon }\end{array}$ & Saxena (2014) \\
\hline Bt-Toxins & $\begin{array}{l}\text { Bacillus } \\
\text { thuringiensis }\end{array}$ & Bioinsecticides endotoxins & $\begin{array}{l}\text { Radhakrishnan } \\
\text { et al. (2017) }\end{array}$ \\
\hline $\begin{array}{l}\text { Phaseolotoxin } \\
\text { (III) }\end{array}$ & Pseudomonas sp. & Phytotoxins-herbicide & $\begin{array}{l}\text { Aguilera et al. } \\
\text { (2017) }\end{array}$ \\
\hline
\end{tabular}

fluorescent Pseudomonas produces siderophores in the presence of a strong chelator 8-Hydroxyquinoline which inhibits pathogens such as Rhizoctonia solani and Sclerotium rolfsii (Kotasthane et al. 2017). Table 5.8 listed some important findings as endophytes as biocontrol agents. Mostly, the biocontrol agents use either nonribosomal peptide synthetase (NRPS) gene and/or type 1 polyketide synthase gene for respective compound production.

\subsubsection{Plant Growth-Promoting Compounds}

Plant growth is regulated by the growth hormones, available nutrient, good environmental condition, and beneficial microbial interaction. Many of the microbes are the prime producers of plant growth hormones, specifically plant-associated or phyllosphere microbial communities produce IAA, gibberellic acids, and cytokines and could fix nitrogen and mobilize nutrients (Dourado et al. 2015). There are many bacteria and fungi which produce IAA, similar to those of plants (Sun et al. 2014; Venkatachalam et al. 2016; Thapa et al. 2018. Microbes use plant tryptophan to produce IAA, which can effectively improve plant growth and enhance overall health (Hayat et al. 2010; Yadav et al. 2015a, b). The genus Methylobacterium is among the most commonly observed leaf epiphytes and represents an abundant and stable member of the phyllosphere microbial community of a wide range of crop plants such as sugarcane (S. officinarum L.), pigeon pea (Cajanus cajan L.), mustard (Brassica campestris L.), potato (Solanum tuberosum L.), and radish (Raphanus sativus L.) (Meena et al. 2012), and has produced variety of growth-promoting phytohormones. The association of plant growth-promoting bacteria (PGPB), especially Methylobacterium sp., with plant hosts greatly benefits plant growth by production of phytohormones like auxins and cytokinins, and increased activity of enzymes such as urease and 1-aminocyclopropane-1-carboxylate deaminase (ACCD), which promotes growth and enhances the production of siderophores, thereby enhancing the uptake of essential nutrients.

The benefits associated with plant-microbe interactions are also dependent on the variety of inoculation methods such as soil, foliar, and combination of both soil 
5 Phyllospheric Microbiomes: Diversity, Ecological ...

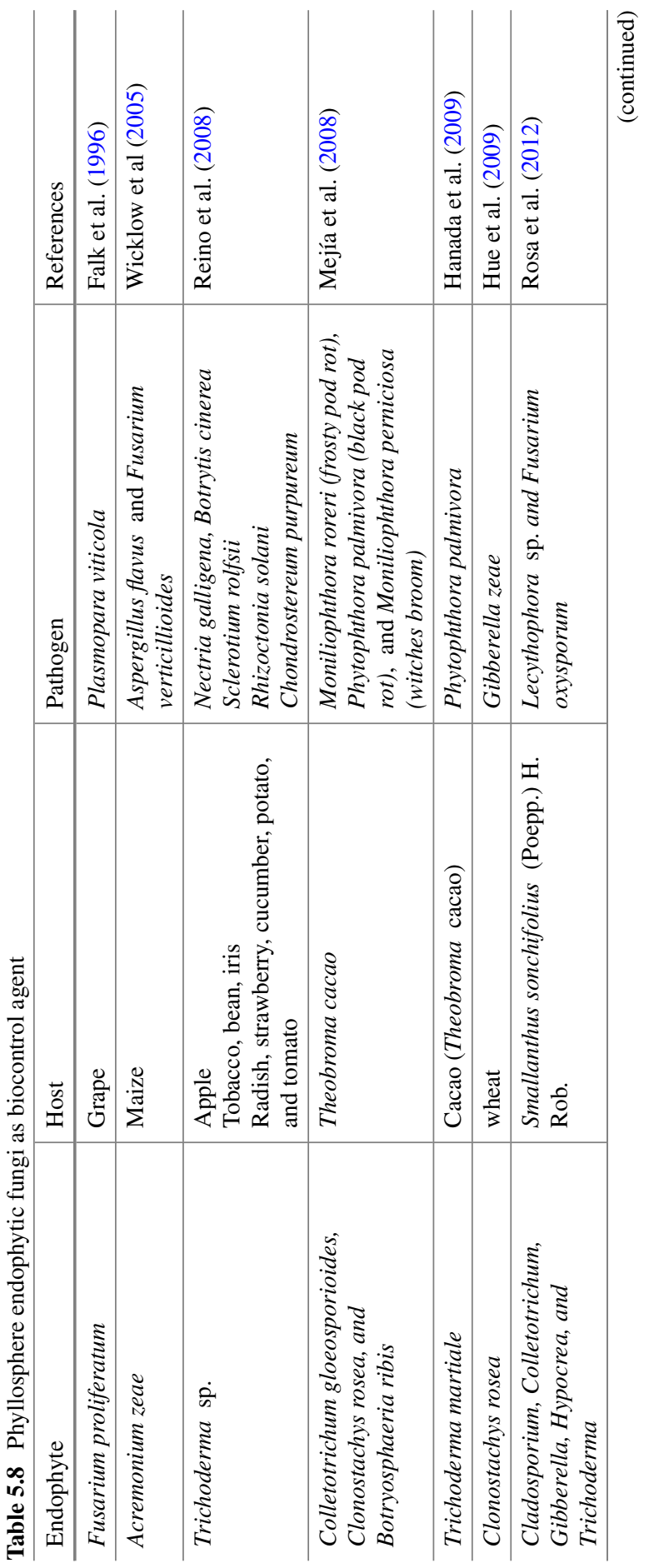




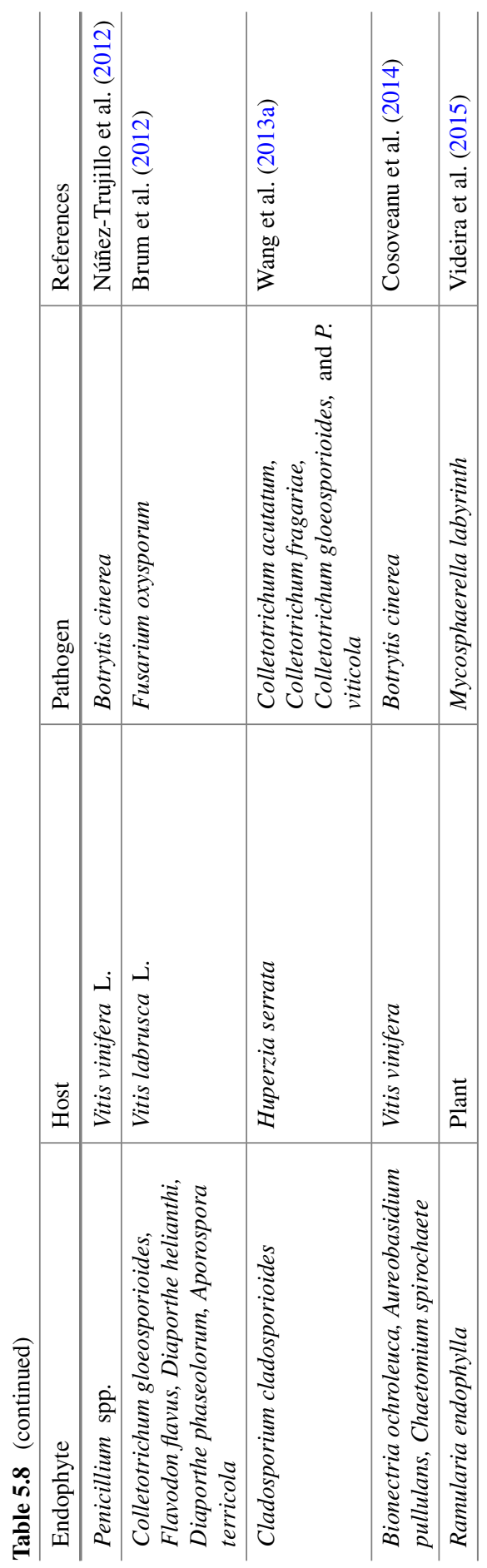


and foliar inoculations (Lee et al. 2011). A study has been conducted to investigate the inoculation of Erwinia herbicola on plant growth by IAA production. The test results showed that about $65 \%$ of the E. herbicola strain recovered from the leaves showed higher expression of the ipdC gene than in culture. The study indicated that physical or chemical microclimates directly influence the differential expression of ipdC (Brandl et al. 2001). Similarly, endophytic bacteria such as Bacillus pumilus E2S2 (Luo et al. 2012), B. amyloliquefaciens NBRI-SN13 (Nautiyal et al. 2013), B. atrophaeus EY6 and B. sphaericus B EY30, B. subtilis EY2, S. kloosii EY37, and K. erythromyxa EY43 (Karlidag et al. 2011) also produce PGPs.

Endophytic Bacillus produces phytohormones such as abscisic acid, auxins, brassinosteroids, cytokinins, ethylene, gibberellins, jasmonates, and strigolactones, and increases nutrient (nitrogen and phosphorous) accessibility to the host (ReinholdHurek and Hurek 2011; Brader et al. 2014; Santoyo et al. 2016; Shahzad et al. 2016; Ek-Ramos et al. 2019). Zeiller et al. (2015) reported that C. botulinum 2301 significantly produce PGPs in a field experiment of clover. A cold-tolerant bacterial strain Exiguobacterium acetylicum 1P promotes wheat seedlings growth (Selvakumar et al. 2010), Brevibacillus brevis improve the growth of cotton crop (Nehra et al. 2016) and Bacillus spp. induce phosphate solubilization more efficiently when present as endophytes in citrus (Giassi et al. 2016). The diazotrophic bacteria associated with phyllosphere gives benefits to the plant by fixing atmospheric nitrogen, solubilization of phosphorus (P), and utilization of available nutrients through its organic end product-mediated solubilization of rock phosphates (Mohammadi 2012; Kembel et al. 2014; Mwajita et al. 2013; Batool et al. 2016; Lambais et al. 2017).

\subsubsection{Biopharmaceutical Importance}

Biological activity of medicinal plants and their applications in various healing properties have been documented well. In recent years, microbes associated with plants themselves proved with high therapeutic values particularly endophytes. Endophytic microbes are known for their beneficial effects to the host, specifically phytohormones, enzymes, and stress-resistant physiology, and its biotechnological potentials (Parthasarathi et al. 2012; Singh and Dubey 2015; Gouda et al. 2016). Endophytes are known to produce bioactive metabolites, which served as a potent drug for medical and cosmetic industries (Shukla et al. 2014; Gouda et al. 2016). Secondary metabolites produced by the endophytic bacteria, actinomycetes, and fungi have economically valuable compounds such as alkaloids, flavonoids, phenolic acids, quinones, steroids, saponins, terpenoids, tetralones, xanthones, etc. (Strobel and Daisy 2003; Joseph and Priya 2011; Godstime et al. 2014; Shukla et al. 2014; Gouda et al. 2016). For example, endophytic microbes are well-known producers of taxol, a diterpene alkaloid, and lignin such as cathartics, emetics, and cholagogue used for cancer treatment (Konuklugil 1995; Zhang et al. 2009; Nair and Padmavathy 2014; Soliman 
Table 5.9 Pharmaceutical valuable products from phyllosphere microbes

\begin{tabular}{|c|c|c|c|}
\hline Producer & Compound & Activity against & References \\
\hline $\begin{array}{l}\text { Hypericum } \\
\text { perforatum, } \\
\text { Diaporthe helianthi }\end{array}$ & $\begin{array}{l}\text { Hypericin, emodin, } \\
\text { tyrosol }\end{array}$ & Salmonella sp. & $\begin{array}{l}\text { Joseph and Priya } \\
\text { (2011), Specian et al. } \\
\text { (2012) }\end{array}$ \\
\hline $\begin{array}{l}\text { Ganoderma } \\
\text { boninense }\end{array}$ & $\begin{array}{l}\text { Rapamycin, } \\
\text { cyclododecane, } \\
\text { petalostemumol }\end{array}$ & Bacillus subtilis & $\begin{array}{l}\text { Parthasarathi et al. } \\
\text { (2012), Ismail et al. } \\
\text { (2014) }\end{array}$ \\
\hline $\begin{array}{l}\text { Fusarium sp. } \\
\text { Cryptosporiopsis } \\
\text { quercina }\end{array}$ & $\begin{array}{l}\text { Xularosides, } \\
\text { munumbicins, } \\
\text { Saadamycin, } \\
\text { cryptocandin }\end{array}$ & Candida albicans & $\begin{array}{l}\text { Jalgaonwala et al. } \\
\text { (2011), Dutta et al. } \\
\text { (2014) }\end{array}$ \\
\hline $\begin{array}{l}\text { Streptomyces sp., } \\
\text { Kennedia nigricans }\end{array}$ & Munumbicins & Vibrio cholerae & Kumar et al. (2014) \\
\hline $\begin{array}{l}\text { Cryptosporiopsis } \\
\text { quercina }\end{array}$ & Saadamycin & $\begin{array}{l}\text { Campylobacter } \\
\text { jejuni }\end{array}$ & Dutta et al. (2014) \\
\hline Streptomyces sp. & $\begin{array}{l}\text { Kakadumycin A, } \\
\text { hypericin }\end{array}$ & Shigella sp. & $\begin{array}{l}\text { Golinska et al. } \\
\text { (2015), Joseph and } \\
\text { Priya (2011) }\end{array}$ \\
\hline $\begin{array}{l}\text { Streptomyces } \\
\text { tsusimaensis }\end{array}$ & Valinomycin & Corona virus & Alvin et al. (2014) \\
\hline $\begin{array}{l}\text { Fusarium } \\
\text { proliferatum }\end{array}$ & $\begin{array}{l}\text { Kakadumycin, } \\
\text { beauvericin }\end{array}$ & $\begin{array}{l}\text { Listeria } \\
\text { monocytogenes }\end{array}$ & Golinska et al. (2015) \\
\hline $\begin{array}{l}\text { Boesenbergia } \\
\text { rotunda Streptomyces } \\
\text { coelicolor }\end{array}$ & Munumbicins & Escherichia coli & $\begin{array}{l}\text { Golinska et al. } \\
\text { (2015), Singh and } \\
\text { Dubey (2015) }\end{array}$ \\
\hline Grammothele lineata & Paclitaxel & Anticancer & $\begin{array}{l}\text { Das et al. (2017), } \\
\text { Kasaei et al. (2017), } \\
\text { Soliman and Raizada } \\
\text { (2018) }\end{array}$ \\
\hline
\end{tabular}

and Raizada 2018). There are many novel metabolites with antibacterial, antifungal, antiviral, anticancer, and antihelminthic activity isolated from plant-associated microbes (Gouda et al. 2016; Kasaei et al. 2017) (Table 5.9).

\subsubsection{Other Applications}

Besides the use of phyllosphere microbes for enhanced growth as well as biocontrol agent, some plant-associated bacteria helps the plant to improve phytoremediation of toxins. For example, hydroxamate siderophores producing bacteria compact heavy metal toxicity and improve the phytoremediation property in A. thaliana (Grobelak and Hiller 2017). Some endophytes provide additional functions to the host plant like drought tolerance, for example, endophytic B. subtilis strain B26 induces drought 
resistance to Brachypodium distachyon grass. The drought resistance mechanism is due to a specific carbohydrate metabolism, the endophytic bacteria increases stressresponsive raffinose-related family carbohydrates in the host (Gagné-Bourque et al. 2015). In another example, the endophytic association increases osmotic responses of the host plant. Endophytic strains such as Arthrobacter sp. and Bacillus spp. in pepper plant increase the proline accumulation, which gives osmotic tolerance (Sziderics et al. 2007).

Further, endophytic bacterial inoculants provide abiotic stress tolerance mechanism to the host by its extracellular enzymes. For example, the endophytic association of various Bacillus spp. increases the superoxide dismutase, phenylalanine lyase, catalase, and peroxidase enzymes activity in gladiolus plants under sodium high concentration conditions (Damodaran et al. 2014). Little studies reported that isolation of endophytic bacteria and their enzyme production potential vary when it colonizes in the plant tissues. Moreover, Jalgaonwala et al. (2011) observed maximum proteolytic activity in Lactobacillus fermentum isolated from leaves of Vinca rosea, which is considered greater to nonendophytic isolates. Similarly, endophytic fungi isolated from Ocimum sanctum and Aloe vera has better enzymatic activity (Yadav et al. 2015a, b). Besides these mechanisms, plant-associated microorganisms improve nutrient acquisition by supplying minerals and other micro/macronutrients from the soil (Singh et al. 2017; Singh and Singh 2017). Above all merits provide new insights in the field of phyllosphere microbiome and its essentiality of interactions to host plant growth and protection and also its significant role in the ecosystem.

\subsubsection{Conclusion and Future Prospects}

The phyllosphere is a unique environment colonized by a wide variety of microorganisms including epiphytes and endophytes, beneficial and pathogenic, bacteria, fungus, viruses, etc. Understanding the phyllosphere community structure, networking, and physiology is a great challenge. However, extensive research on phyllosphere microbiota gives great potential for the applications in economic plant productivity, specifically agriculture and forestry, ecosystem cleaning, and health. Hitherto, both in vitro and in vivo experiments are required to improve the understanding of microbial aggregations in the phyllosphere and dynamic play in the ecosystem. Based on the literature understanding, further and future studies should aim to (1) study the community interplay within the closely related and distanced microbial interactions and its stimulatory response on host plant and ecosystem, (2) to know the potentials of beneficial microbes and their commercial value, (3) impact on climate change on phyllosphere microbiome, and their contribution to climate change, (4) moreover, documentation of host-specific, geographic-specific, and seasonal-specific microbial interactions-guiding host-parasite and beneficial-pathogen interactions. Besides, phyllosphere microbiome research assures to understand the current challenges highlighting the terrestrial ecosystem change and the impact of global warming, especially the dominance of pathogenesis. 
Acknowledgements Authors thank DST-PURSE, Madurai Kamaraj University for providing Internet and computer facility and Department of Biotechnology, India for providing the infrastructure facilities.

\section{References}

Abdelfattah A, Nicosia MGLD, Cacciola SO, Droby S, Schena L (2015) Metabarcoding analysis of fungal diversity in the phyllosphere and carposphere of olive (Olea europaea). PLoS ONE 10:e0131069

Agler MT, Ruhe J, Kroll S, Morhenn C, Kim ST, Weigel D et al (2016) Microbial hub taxa link host and abiotic factors to plant microbiome variation. PLoS Biol 14:e1002352

Aguilera S, Alvarez-Morales A, Murillo J, Hernández-Flores JL, Bravo J, De la Torre-Zavala S (2017) Temperature-mediated biosynthesis of the phytotoxin phaseolotoxin by Pseudomonas syringae pv. phaseolicola depends on the autoregulated expression of the phtABC genes. PLoS ONE 12(6): e0178441. https://doi.org/10.1371/journal.pone.0178441

Ahmed E, Holmström SJM (2014) Siderophores in environmental research: roles and applications: siderophores in environmental research. Microbial Biotechnol 7:196-208

Aleklett K, Hart M, Shade A (2014) The microbial ecology of flowers: an emerging frontier frontier in phyllosphere research. Botany 92:253-266

Alvin A, Kristin I, Miller B, Neilan A (2014) Exploring the potential of endophytes from medicinal plants as sources of antimycobacterial compounds. Microbiol Res 169:483-495

Amine Hassani M, Durán P, Hacquard S (2018) Microbial interactions within the plant holobiont. Microbiome 6:58

Andrews JH, Harris RF (2000) The ecology and biogeography of microorganisms on plant surfaces. Ann Rev Phytopathol 38:145-180

Ansede JH, Frieman R, Yoch DC (2001) Phylogenetic analysis of culturable dimethyl sulfideproducing bacteria from a spartina-dominated salt marsh and estuarine water. Appl Environ Microbiol 67:1210-1217

Arnold AE, Maynard Z, Gilbert GS, Coley PD, Kursar TA (2000) Are tropical fungal endophytes hyperdiverse? Ecol Lett 3:267-274

Arnold AE, Henk DA, Eells RL, Lutzoni F, Vilgalys R (2007) Diversity and phylogenetic affinities of foliar fungal endophytes in loblolly pine inferred by culturing and environmental PCR. Mycologia 99:185-206

Aung K, Jiang Y, Yang He S (2018) The role of water in plant-microbe interactions. The Plant Journal 93:771-780

Bai Y, Muller DB, Srinivas G, Garrido-Oter R, Potthoff E, Rott M, Dombrowski N, Münch PC, Spaepen S, Remus-Emsermann M, Hüttel B, McHardy AC, Vorholt JA, Schulze-Lefert P (2015) Functional overlap of the Arabidopsis leaf and root microbiota. Nature 528:364

Baldwin HE, Bhatia ND, Friedman A, Eng RM, Seite S (2017) The role of cutaneous microbiota harmony in maintaining a functional skin barrier. J Drugs Dermatol 16:12-18

Balint M, Tiffin P, Hallstrom B, O'Hara RB, Olson MS, Fankhauser JD, Piepenbring M, Schmitt I (2013) Host genotype shapes the foliar fungal microbiome of balsam poplar (Populus balsamifera). PLoS ONE 8:e53987

Balint-Kurti P, Simmons SJ, Blum JE, Ballare CL, Stapleton A (2010) Maize leaf epiphytic bacteria diversity patterns are genetically correlated with resistance to fungal pathogen infection. Mol Plant-Microbe Interact 23:473-484

Beattie GA (2002) Leaf surface waxes and the process of leaf colonization by microorganisms. In: Lindow SE, Hecht-Poinar EI, Elliott VJ (eds) Phyllosphere microbiology. APS Press, St. Paul, USA, pp 3-26 
Beattie GA (2011) Water relations in the interaction of foliar bacterial pathogens with plants. Ann Rev Phytopathol 49:533-555

Beattie GA, Lindow SE (1999) Bacterial colonization of leaves: a spectrum of strategies. Phytopathology 89:353-359

Beilsmith K, Thoen MPM, Brachi B, Gloss AD, Khan MH, Bergelson J (2019) Genome-wide association studies on the phyllosphere microbiome: embracing complexity in host-microbe interactions. Plant J 97:164-181

Belova SE, Baani M, Suzina NE, Bodelier PLE, Liesack W, Dedysh SN (2011) Acetate utilization as a survival strategy of peat-inhabiting Methylocystis spp. Environ Microbiol Rep 3(1):36-46. https://doi.org/10.1111/j.1758-2229.2010.00180.x

Berestetskii AO, Yuzikhin OS, Katkova AS, Dobrodumov AV, Sivogrivov DE, Kolombet LV (2010) Isolation, identification, and characteristics of the phytotoxin produced by the fungus Alternaria cirsinoxia. Appl Microbiol Biot 46:75-79

Bernal E, Celis S, Galíndez X, Moratto C, Sánchez J, García D (2006) Microflora cultivable endomicorrizas obtenidas en hojarasca de bosque (Páramo Guerrero finca Puente de Tierra) Zipaquirá, Colombia. Acta Biol Colomb 11:125-130

Bhattacharyya LH, Borah G, Parkash V, Bhattacharyya PN (2017) Fungal endophytes associated with the ethnomedicinal plant Meyna spinosa Roxb. Current Life Sci 3(1):1-5

Bian GK, Qin S, Yuan B, Zhang YJ, Xing K, Ju XJ et al (2012) Streptomyces phytohabitans sp. nov., a novel endophytic actinomycete isolated from medicinal plant Curcuma phaeocaulis. Antonie Van Leeuwenhoek 102:289-296

Block A, Schmetz E, Jones JB, Klee HJ (2005) Coronatine and salicyclic acid: the battle between Arabidopsis and Pseusomonas for phytohormone control. Mol Plant Pathol 6:79-83

Bodenhausen N, Horton MW, Bergelson J (2013) Bacterial communities associated with the leaves and the roots of Arabidopsis thaliana. PLoS ONE 8:e56329

Bodenhausen N, Bortfeld-Miller M, Ackermann M, Vorholt JA (2014) A synthetic community approach reveals plant genotypes affecting the phyllosphere microbiota. PLoS Genet 10:e1004283

Bogdanove AJ (2002) Protein-protein interactions in pathogen recognition by plants. Plant Mol Biol 50(6):981-989

Boller T, Felix G (2009) A renaissance of elicitors: perception of microbe-associated molecular patterns and danger signals by pattern-recognition receptors. Annu Rev Plant Biol 60:379-406

Brader G, Compant S, Mitter B, Trognitz F, Sessitsch A (2014) Metabolic potential of endophytic bacteria. Curr Opin Biotechnol 27:30-37

Brandl MT, Quinones B, Lindow SE (2001) Heterogeneous transcription of an indoleacetic acid biosynthetic gene in Erwinia herbicola on plant surfaces. Proc Natl Acad Sci 98 (6):3454-3459

Brewer CA, Smith WK, Vogelmann TC (1991) Functional interaction between leaf trichomes, leaf wettability and the optical properties of water droplets. Plant Cell Environ 14:955-962

Bringel F, Couee I (2015) Pivotal roles of phyllosphere microorganisms at the interface between plant functioning and atmospheric trace gas dynamics. Front Microbiol 6:486

Brum MCP, Araújo WL, Maki CS, Azevedo JL (2012) Endophytic fungi from Vitis labrusca L. ('Niagara Rosada') and its potential for the biological control of Fusarium oxysporum. Genet Mol Res 11:4187-4197

Buee M, De Boer W, Martin F, Van Overbeek L, Jurkevitch E (2009) The rhizosphere zoo: an overview of plant-associated communities of microorganisms, including phages, bacteria, archaea, and fungi, and of some of their structuring structuring factors. Plant Soil 321:189-212

Bulgarelli D, Schlaeppi K, Spaepen S, Loren V, van Themaat E, Schulze- Lefert P (2013) Structure and functions of the bacterial microbiota of plants. Ann Rev Plant Biol 64:807-838

Bull C, Wadsworth M, Sorensen K, Takemoto J, Austin R, Smilanick J (1998) Syringomycin E produced by the biological control agents control green mold on lemons. Biol Control 12:89-95

Burch AY, Zeisler V, Yokota K, Schreiber L, Lindow SE (2014) The hygroscopic biosurfactant syringafactin produced by Pseudomonas syringae enhances fitness on leaf surfaces during fluctuating humidity. Environ Microbiol 16:2086-2098 
Carlos A, Ruiz-Pérez SR, Zambranoa MM (2016) Microbial and functional diversity within the phyllosphere of Espeletia Species in an Andean high-mountain ecosystem. Appl Environ Microbiol 82:6

Cha JY, Han S, Hong HJ, Cho H, Kim D, Kwon Y, Kwon SK, Crüsemann M, Yong BL, Kim JF (2016) Microbial and biochemical basis of a Fusarium wilt-suppressive soil

Chen HH, Qin S, Li J, Zhang YQ, Xu LH, Jiang CL et al (2009) Pseudonocardia endophytica sp. nov., isolated from the pharmaceutical plant Lobelia clavata. Int J Syst Evol Microbiol 59:559-563

Chen MH, Zhang L, Zhang X (2011) Isolation and inoculation of endophytic actinomycetes in root nodules of Elaeagnus angustifolia. Mod Appl Sci 5:264-267

Chinchilla D, Bauer Z, Regenass M, Boller T, Felix G (2006) The Arabidopsis receptor kinase FLS2 binds flg22 and determines the specificity of flagellin perception. Plant Cell 18:465-476

Chou HM, Bundock N, Rolfe SA, Scholes JD (2000) Infection of Arabidopsis thaliana leaves with Albugo candida (white blister rust) causes a reprogramming of host metabolism. Mol Plant Pathol Mar 1:99-113

Chowdhury S, Basu A, Kundu S (2015) Cloning, characterization and bacterial overexpression of an osmotin-like protein gene from Solanum nigrum L. with antifungal activity against three necrotrophic fungi. Mol Biotechnol 57:371-381

Coince A, Cordier T, Lengelle J, Defossez E, Vacher C, Robin C, Buée M, Marçais B (2014) Leaf, root-associated fungal assemblages do not follow similar elevational diversity patterns. PLoS ONE 9:e100668

Collier FA, Elliot SL, Ellis RJ (2005) Spatial variation in Bacillus thuringiensis/cereus populations within the phyllosphere of broad-leaved dock (Rumex obtusifolius) and surrounding habitats. FEMS Microbiol Ecol 54(2005):417-425

Coombs JT, Franco CMM (2003) Isolation and identification of actinobacteria from surfacesterilized wheat roots. Appl Environ Microbiol 69:5603-5608

Copeland JK, Yuan L, Layeghifard M, Wang PW, Guttman DS (2015) Seasonal community succession of the phyllosphere microbiome. Mol Plant Microbe Interact 28:274-285

Cordier T, Robin C, Capdevielle X, Fabreguettes O, Desprez-Loustau ML, Vacher C (2012) The composition of phyllosphere fungal assemblages of European beech (Fagus sylvatica) varies significantly along an elevation gradient. New Phytol 196:510-519

Cosoveanu A, Gimenez-Mariño C, Cabrera Y, Hernandez G, Cabrera R (2014) Endophytic fungi from grapevine cultivars in Canary Islands and their activity against phytopatogenic fungi. Int $\mathrm{J}$ Agric Crop Sci 7(15):1497-1503

Craig A, Ewan R, Mesmar J, Gudipati V, Sadanandom A (2009) E3 ubiquitin ligases and plant innate immunity. J Exp Bot 60:1123-1132

Cui H, Xiang T, Zhou JM (2009) Plant immunity: a lesson from pathogenic bacterial effector proteins. Cell Microbiol 11:1453-1446

Damodaran T, Rai RB, Jha SK, Kannan R, Pandey BK, Sah V et al (2014) Rhizosphere and endophytic bacteria for induction of salt tolerance in gladiolus grown in sodic soils. J Plant Interact 9:577-584

Das A, Rahman MI, Ferdous AS, Amin A, Rahman MM, Nahar N et al (2017) An endophytic Basidiomycete, Grammothele lineata, isolated from Corchoru solitorius, produces paclitaxel that shows cytotoxicity. PLoSONE 12(6):e0178612

Dees MW, Lysøe E, Nordskog B, Brurberg MB (2015) Bacterial communities associated with surfaces of leafy greens: shift in composition and decrease in richness over time. Appl Environ Microbiol 81:1530-1539

Degnan PH, Ochman H (2012) Illumina-based analysis of microbial community diversity. ISME J 6:183-194

Deka D, Jha DK (2018) Antimicrobial activity of Endophytic Fungi from leaves and barks of Litsea cubeba Pers., A Traditionally important medicinal plant of north east India. Jordan J Biol Sci 11(1):73-79 
DeLeon-Rodriguez N, Lathem TL, Rodriguez-R LM, Barazesh JM, Anderson BE, Beyersdorf AJ et al (2013) Microbiome of the upper troposphere: species composition and prevalence, effects of tropical storms, and atmospheric implications. Proc Natl Acad Sci USA 110:2575-2580

Delmotte N, Knief C, Chaffron S, Innerebner G, Roschitzki B, Schlapbach R et al (2009) Community proteogenomics reveals insights into the physiology of phyllosphere bacteria. Proc Natl Acad Sci USA 106:16428-16433

Dhayanithy G, Subban K, Chelliah J (2019) Diversity and biological activities of endophytic fungi associated with Catharanthus roseus. BMC Microbiol 19(1):22

Dinesh R, Srinivasan VTES, Anandaraj M, Srambikkal H (2017) Endophytic actinobacteria: diversity, secondary metabolism and mechanisms to unsilence biosynthetic gene clusters. Crit Rev Microbiol 43:546-566

Ding L et al (2011) Resistance to hemi-biotrophic Fusarium graminearum infection is associated with coordin

Dingman DW (2000) Growth of Escherichia coli O157:H7 in bruised apple (Malus domestica) tissue as influenced by cultivar, date of harvest, and source. Appl Environ Microbiol 66:1077-1083

Dobrovol'skaya T, Khusnetdinova K, Manucharova N, Golovchenko A (2017) Structure of epiphytic bacterial communities of weeds. Microbiology 86:257-263

Doronina NV, Ivanova EG, Suzina NE, Trotsenko YA (2004) Methanotrophs and methylobacteria are found in woody plant tissues within the winter period. Microbiology 73(6):702-709

Dourado MN, Neves AAC, Santos DS, Araujo WL (2015) Biotechnological and agronomic potential of endophytic pink-pigmented methylotrophic trophic Methylobacterium spp. Biomed Res Int 2015:909016

Du HJ, Zhang YQ, Liu HY, Su J, Wei YZ, Ma BP et al (2013) Allonocardiopsis opalescens gen. nov., sp. nov., a new member of the suborder Streptosporangineae, from the surface- sterilized fruit of a medicinal plant. Int J Syst Evol Microbiol 63:900-904

Duke SO, Dayan FE (2011) Modes of action of microbial produced phytotoxins. Toxins 3:10381064

Duke SO, Evidente A, Fiore M, Rimando AM, Dayan FE, Vurro M, Christiansen N, Looser R, Hutzler J, Grossman K (2011) Effect of aglycone of ascaulitoxin in amino acid metabolism of Lemna paucicostata. Pestic Biochem Physiol 100:41-50

Durand A, Maillard F, Alvarez-Lopez V, Guinchard S, Bertheau C, Valot B et al (2018) Bacterial diversity associated with poplar trees grown on a $\mathrm{Hg}$-contaminated site: community characterization and isolation of $\mathrm{Hg}$-resistant plant growth promoting bacteria. Sci Total Environ 622:1165-1177

Dutta D, Puzari KC, Gogoi R, Dutta P (2014) Endophytes: exploitation as a tool in plant protection. Braz Arch Biol Technol 57:621-629

Ek-Ramos MJ, Gomez-Flores R, Orozco-Flores AA, Rodríguez-Padill C, González-Ochoa G, Tamez-Guerra P (2019) Bioactive products from plant-endophytic gram-positive bacteria. Front Microbiol 10:463

El-Din Hassan S (2017) Plant growth-promoting activities for bacterial and fungal endophytes isolated from medicinal plant of Teucrium polium L J Adv Res 8(6):687-695

El-Komy MH (2014) Comparative analysis of defense responses in chocolate spot-resistant and susceptible faba bean (Vicia faba) cultivars following infection by the necrotrophic fungus Botrytis fabae. Plant Pathol J 30:355-366

El-Tarabily KA (2003) An endophytic chitinase-producing isolate of Actinoplanes missouriensis, with potential for biological control of root rot of lupin caused by Plectosporium tabacinum. Aust J Bot 51:257-266

Ernawati M, Solihin DD, Lestari Y (2016) Community structures of endophytic actinobacteria from medicinal plant Centella asiatica L. Urbanbased on metagenomic approach. Int J Pharm Pharm Sci 8:292-297

Erwin DC, Ribeiro OK (1996) Phytophthora diseases worldwide. APS press, New York 
Esser DS, Leveau JHJ, Meyer KM, Wiegand K (2015) Spatial scales of interactions among bacteria and between bacteria and the leaf surface. FEMS Microbiol Ecol. https://doi.org/10.1093/femsec/ fiu034

Fahimipour AK, Kardish MR, Lang JM, Green JL, Eisen JA, Stachowicz JJ (2017) Global-scale structure of the Eelgrass microbiome. Appl Environ Microbiol 83:e03391-16

Falk SP, Pearson RC, Gadoury DM, Seem RC, Sztejnberg A (1996) Fusarium proliferatum as a biocontrol agent against grape downy mildew. Phytopathology 86:1010-1017

Feng WW, Wang T, Bai JL, Ding P, Xing K, Jiang JH et al (2017) Glutamicibacter halophytocola sp. nov., an endophytic actinomycete isolated from the roots of a coastal halophyte, Limonium sinense. Int J Syst Evol Microbiol 67:1120-1125

Finkel OM, Burch AY, Lindow SE, Post AF, Belkin S (2011) Geographical location determines the population structure in phyllosphere microbial communities of a salt-excreting desert tree. Appl Environ Microbiol 77:7647-7655

Finlay AC, Hobby GL, Pan SY, Regna PP, Routein JB, Seeley DB, Shull GM, Sobin BA, Solomans IA, Vinson JW, Kane JH (1950) Terramycin, a new antibiotic. Science 111:85

Foley RC, Kidd BN, Hane JK, Anderson JP, Singh K (2016) Reactive oxygen species play a role in the infection of the necrotrophic fungi Rhizoctoniasolani in wheat. PLoS ONE 11:e0152548

Freiberg E (1998) Microclimatic parameters influencing nitrogen fixation in the phyllosphere in a Costa Rican premontane rain forest. Oecologia 117(1):9-18

Fukunaga K (1955) Blasticidin, a new antiphytopathogenic fungal substance. Part I. Bull Agric Chem Soc Jpn 19:181-188

Furnkranz M, Wolfgang W, Andreas R, Guy A, Frank R, Angela S (2008) Nitrogen fixation by phyllosphere bacteria associated with higher plants plants and their colonizing epiphytes of a tropical lowland rainforest of Costa Rica. ISME J 2(5):561-570

Gagné-Bourque F, Mayer BBF, Charron JBB, Vali H, Bertrand A, Jabaji S (2015) Accelerated growth rate and increased drought stress resilience of the model grass Brachypodium distachyon colonized by Bacillus subtilis B26. PLoS ONE 10:e130456

Gaige AR, Ayella A, Shuai B (2010) Methyl jasmonate and ethylene induce partial resistance in Medicago truncatula against the charcoal rot pathogen Macrophomina phaseolina. Physiol Mol Plant Pathol 74:412-418

Galbally IE, Kirstine W (2002) The production of methanol by flowering plants and the global cycle of methanol. J Atmosph Chem 43:195-229

Gan P, Ikeda K, Irieda H, Narusaka M, O’Connell RJ, Narusaka Y, Takano Y, Kubo Y, Shirasu K (2013) Comparative genomic and transcriptomic analyses reveal the hemibiotrophic stage shift of Colletotrichum fungi. New Phytol 197:1236-1249

Gerwick BC, Fields SS, Chapin EL, Cleveland JA, Heim DR (1997) Pyrizadocidin, a new microbial phytotoxin with activities in a Mehler's reaction. Weed Sci 45:654-657

Giassi V, Kiritani C, Kupper KC (2016) Bacteria as growth-promoting agents for citrus rootstocks. Microbiol Res 190:46-54

Glenn DM, Bassett C, Dowd SE (2015) Effect ofpest management system on 'Empire' apple leaf phyllosphere populations. Sci Horticult 183:58-65

Glushakova AM, Chernov IY (2004) Seasonal dynamics in a yeast population on leaves of the common wood sorrel Oxalis acetosella L. Microbiology 73:184-188

Godstime OC, Enwa FO, Augustina JO, Christopher EO (2014) Mechanisms of antimicrobial actions of phytochemicals against enteric pathogens-a review. J Pharm Chem Biol Sci 2:77-85

Gołębiewski M, Tarasek A, Sikora M, Deja-Sikora E, Tretyn A, Niklińska M (2019) Rapid microbial community changes during initial stages of pine litter decomposition. Microb Ecol 77:56-75

Golinska P, Wypij M, Agarkar G, Rathod D, Dahm H, Rai M (2015) Endophytic actinobacteria of medicinal plants: diversity and bioactivity. Antonie Van Leeuwenhoek 108:267-289

Gottwald S, Samans B, Luck S, Friedt W (2012) Jasmonate and ethylene dependent defense gene expression and suppression of fungal virulence factors: two essential mechanisms of Fusarium head blight resistance in wheat? BMC Genom 13:369 
Gouda S, Das G, Sen SK, Shin HS, Patra JK (2016) Endophytes: a treasure house of bioactive compounds of medicinal importance. Front Microbiol 7:1538

Gourion B, Rossignol M, Vorholt JA (2006) A proteomic study of Methylobacterium extorquens reveals a response regulator essential for epiphytic growth. Proc Natl Acad Sci USA 103:1318613191

Gourion B, Francez-Charlot A, Vorholt JA (2008) PhyR is involved in the general stress response of Methylobacterium extorquens AM1. Journal of Bacteriol 190(3):1027-1035. https://doi.org/ 10.1128/JB.01483-07

Green PN (2006) Methylobacterium. The Prokaryotes, vol 5 (Falkow S, Rosenberg E, Schleifer K-H, Stackebrandt E, Dworkin M, eds). Springer, New York, NY, pp 257-265

Grobelak A, Hiller J (2017) Bacterial siderophores promote plant growth: Screening of catechol and hydroxamate siderophores. Int J Phytorem 19(9):825-833

Guerreiro MA, Brachmann A, Begerow D, Peršoh D (2018) Transient leaf endophytes are the most active fungi in 1-year-old beech leaf litter. Fungal Divers 89:237-251

Hahn DR, Graupner RC, Chapin E, Gray J, Heim D, Gilbert JR, Gerwick BC (2009) Albucidin: a novel bleaching herbicide from Streptomyces albus subsp. chlorinus NRRL B- 24108. J Antibiot 62:191-194

Hamd Elmagzob AA, Ibrahim MM, Zhang G-F (2019) Seasonal diversity of endophytic bacteria associated with Cinnamomum camphora (L.) Presl. Diversity 11:112

Han JS, Cheng JH, Yoon TM, Song J, Rajkarnikar A, Kim WG, Yoo ID, Yang YY, Suh JW (2005) Biological control of common scab diseases by antagonistic strain Bacillus sp. sunhua. J Appl Microbiol 99:213-221

Hanada RE, Pomella AWV, Soberanis W, Loguercio LL, Pereira JO (2009) Biocontrol potential of Trichoderma martiale against the black-pod disease (Phytophthora palmivora) of cacao. Biol Control 50:143-149

Harsonowati W, Astuti RI, Wahyudi AT (2017) Leaf blast disease reduction by rice-phyllosphere actinomycetes producing bioactive compounds. J Gen Plant Pathol 83:98-108

Hayat R, Ali S, Amara U, Khalid R, Ahmed I (2010) Soil beneficial bacteria and their role in plant growth promotion: a review. Ann Microbiol 60:579-598

He H, Liu C, Zhao J, Li W, Pan T, Yang L et al (2014) Streptomyces zhaozhouensis sp. nov., an actinomycete isolated from Candelabra aloe (Aloe arborescens Mill). Int J Syst Evol Microbiol 64:1096-1101

Hill TC, Moffett BF, Demott PJ, Georgakopoulos DG, Stump WL, Franc GD (2014) Measurement of ice nucleation-active bacteria on plants and in precipitation by quantitative PCR. Appl Environ Microbiol 80:1256-1267

Hirano SS, Upper CD (1983) Ecology and epidemiology of foliar bacterialplant pathogens. Ann Rev Phytopathol 21:243-269

Hirano SS, Upper CD (2000) Bacteria in the leaf ecosystem with emphasis on Pseudomonas syringae - a pathogen, ice nucleus, and epiphyte. Microbiol Mol Biol Rev 64:624-653

Hoagland RE, Douglas Boyette C, Weaver MA, Abbas HK (2007) Bioherbicides: research and risks. Toxin Rev 26:313-342

Holland MA, Davis R, Moffitt S, O'Laughlin K, Peach D, Sussan S et al (2000) Using "leaf prints" to investigate a common bacterium. Am Biol Teach 62:128-131

Horton MW, Bodenhausen N, Beilsmith K, Meng DZ, Muegge BD, Subramanian S, Vetter MM, Vilhjálmsson BJ, Nordborg M, Gordon JI, Bergelson J (2014) Genome-wide association study of Arabidopsis thaliana leaf microbial community. Nat Commun 5:5320

Huang MJ, Rao MP, Salam N, Xiao M, Huang HQ, Li WJ (2017) Allostreptomyces psammosilenae gen. nov., sp. nov., an endophytic actinobacterium isolated from the roots of Psammosilene tunicoides and emended description of the family Streptomycetaceae. Int J Syst Evol Microbiol 67:288-293

Huang LH, Yuan MQ, Ao XJ, Ren AY, Zhang HB, Yang MZ (2018) Endophytic fungi specifically introduce novel metabolites into grape flesh cells in vitro. PLoS ONE 13(5):e0196996 
Hue AG, Voldeng HD, Savard ME, Fedak G, Tian X, Hsiang T (2009) Biological control of fusarium head blight of wheat with Clonostachys rosea strain ACM941. Can J Plant Pathol 31:169-179

Hunter PJ, Hand P, Pink D et al (2010) Both leaf properties and microbe-microbe interactions influence within-species variation in bacterial population diversity and structure in the lettuce (Lactuca species) phyllosphere. Appl Environ Microbiol 76:8117-8125

Ichihara AK, Shiraishi K, Sato H, Sakamura S, Nishiyama K, Sasaki R, Furusaki A, Matsumoto T (1977) The structure of coronatine. J Am Chem Soc 99:636-637

Iguchi H, Sato I, Yurimoto H, Sakai Y (2013) Stress resistance and C1 metabolism involved in plant colonization of a methanotroph Methylosinus sp. B4S. Arch Microbiol 195:717-726

Iguchi H, Yurimoto H, Sakai Y (2015) Interactions of methylotrophs with plants and other heterotrophic bacteria. Microorganisms 3(2):137-151

Ikeda S, Anda M, Inaba S et al (2011) Autoregulation of nodulation interferes with impacts of nitrogen fertilization levels on the leaf-associated bacterial community in soybeans. Appl Environ Microbiol 77:1973-1980

Inacio J, Pereira P, de Carvalho M, Fonseca A, Amaral- Collaco MT, Spencer-Martins I (2002) Estimation and diversity of phylloplane mycobiota on selected plants in a Mediterranean-type ecosystem in Portugal. Microbial Ecol 44:344-353

Indananda C, Thamchaipenet A, Matsumoto A, Inahashi Y, Duangmal K, Takahashi Y (2011) Actinoallomurus oryzae sp. nov., an endophytic actinomycete isolated from roots of a Thai jasmine rice plant. Int J Syst Evol Microbiol 61:737-741

Innerebner G, Knief C, Vorholt JA (2011) Protection of Arabidopsis thaliana against leaf-pathogenic Pseudomonas syringae by Sphingomonas strains in a controlled model system. Appl Environ Microbiol 77:3202-3210

Irvine NM, Yerkes CN, Graupner PR, Roberts RE, Hahn DR, Pearce C, Gerwick BC (2008) Synthesis and characterization of synthetic analogs of cinnacidin, a novel phytotoxin from Nectria sp. Pest Manag Sci 64:891-899

Ismail K, Abdullah S, Chong K (2014) Screening for potential antimicrobial compounds from Ganoderma boninense against selected food borne and skin disease pathogens. Int J Pharm Pharm Sci 6:771-774

Ismail MH, Hussain A, Iqbal A, Khan SA, Lee I-J (2018) Endophytic fungus Aspergillus japonicus mediates host plant growth under normal and heat stress conditions. BioMed Res Int. https://doi. org/10.1155/2018/7696831

Ito K, Futatsuya F, Hibi K, Ishida S, Yamada O, Munakata K (1974) Herbicidal activity of 3, 3', 3'-dimethyl-4-methoxybenzophenone (NK-049) in paddy fields. I. Herbicidal characteristics of NK-049 on weeds. Weed Sci 18:10-15

Izhaki I, Fridman S, Gerchman Y, Halpern M (2013) Variability of bacterial community composition on leaves between and within plant species. Curr Microbiol 66:227-235

Jackson EF, Echlin HL, Jackson CR (2006) Changes in the phyllosphere community of the resurrection fern, Polypodium polypodioides, associated with rainfall and wetting. FEMS Microbiol Ecol 58:236-246

Jacob F, Vernaldi S, Maekawa T (2013) Evolution and conservation of plant NLR functions. Front Immunol 4:297

Jacoby R, Peukert M, Succurro A, Koprivova A, Kopriva S (2017) The role of soil microorganisms in plant mineral nutrition—current knowledge and future directions. Front Plant Sci 8:1617

Jalgaonwala RE, Mohite BV, Mahajan RT (2011) Natural products from plant associated endophytic fungi. J Microbiol Biotechnol Res 1:21-32

Jansson RK, Dybas RA (1996) Avermectins: biochemical mode of action, biological activity, and agricultural importance. In: Ishaaya I (ed) Insecticides with novel modes of action: mechanisms and applications. Springer Verlag, Berlin

Jariwala B, Desai B (2018) Isolation and identification of endophytic fungi from various medicinal plants. BMR Microbiology 4(1):1-7

Jia F, Liu C, Wang X, Zhao J, Liu Q, Zhang J et al (2013) Wangella harbinensis gen. nov., sp. nov., a new member of the family Micromonosporaceae. Antonie Van Leeuwenhoek 103:399-408 
Jiang ZK, Pan Z, Li FN, Li XJ, Liu SW, Tuo L et al (2017) Marmoricola endophyticus sp. nov., an endophytic actinobacterium isolated from the Spesia populnea. Int J Syst Evol Microbiol 67:4379-4384

Jiang ZK, Tuo L, Huang DL, Osterman IA, Tyurin AP, Liu SW et al (2018) Diversity, novelty, and antimicrobial activity of endophytic actinobacteria from mangrove plants in Beilun Estuary National Nature Reserve of Guangxi China. Front Microbiol 9:868

Jo Y, Cho JK, Choi H, Chu H, Lian S, Cho WK (2015) Bacterial communities in the phylloplane of Prunus species. J Basic Microbiol 55:504-508

Johnston-Monje D, Raizada MN (2011) Conservation and diversity of seed associated endophytes in Zea across boundaries of evolution, ethnography and ecology. PLoS ONE 6:e20396

Jones K (1970) Nitrogen fixation in the phyllosphere of the Douglas Fir, Pseudotsuga Douglasii. Ann Bot 34:239-244

Jones JDG, Dangl JL (2006) The plant immune system. Nature 444:323-329

Joseph B, Priya RM (2011) Bioactive compounds from endophytes and their potential in pharmaceutical effect: a review. Am J Biochem Mol Bio 1:291-309

Jumpponen A, Jones KL (2009) Massively parallel 454 sequencing indicates hyperdiverse fungal communities in temperate Quercus macrocarpa phyllosphere. New Phytol 184:438-448

Junker RR, Tholl D (2013) Volatile organic compound mediated interactions at the plant-microbe interface. J Chem Ecol 39:810-825

Jupe J et al (2013) Phytophthora capsici-tomato interaction features dramatic shifts in gene expression associated with a hemi-biotrophic lifestyle. Genome Biol 14:R63

Kabbage M, Yarden O, Dickman MB (2015) Pathogenic attributes of Sclerotinia sclerotiorum: Switching from a biotrophic to necrotrophic lifestyle. Plant Sci 233:53-60

Kadivar H, Stapleton AE (2006) Ultraviolet radiation alters maize phyllosphere bacterial diversity. Microbial Ecol 45:353-361

Kaewkla O, Franco CM (2013) Rational approaches to improving the isolation of endophytic actinobacteria from Australian native trees. Microb Ecol 65:384-393

Kaewkla O, Thamchaipenet A, Franco CM (2017) Micromonospora terminaliae sp. nov., an endophytic actinobacterium isolated from the surface sterilized stem of the medicinal plant Terminalia mucronata. Int J Syst Evol Microbiol 225-230

Kannadan S, Rudgers JA (2008) Endophyte symbiosis benefits a rare grass under low water availability. Funct Ecol 22:706-713

Karlidag H, Esitken A, Yildirim E, Donmez MF, Turan M (2011) Effects of plant growth promoting bacteria on yield, growth, leaf water content, membrane permeability, and ionic composition of strawberry under saline conditions. J Plant Nutr 34:34-45

Karlsson I, Friberg H, Steinberg C, Persson P (2014) Fungicide effects on fungal community composition in the wheat phyllosphere. PLoS ONE 9:e111786

Kasaei A, Mobini-Dehkordi M, Mahjoubi F, Saffar B (2017) Isolation of taxol-producing endophytic fungi from iranian yew through novel molecular approach and their effects on human breast cancer cell line. Curr Microbiol 74(6):702-709

Kawaguchi K, Yurimoto H, Oku M, Sakai Y (2011) Yeast methylotrophy and autophagy in a methanol-oscillating environment on growing Arabidopsis thaliana leaves. PLoS ONE 6(9):e25257. https://doi.org/10.1371/journal.pone.0025257

Kecskeméti E, Berkelmann-Löhnertz B, Reineke A, Cantu D (2016) Are epiphytic microbial communities in the carposphere of ripening grape clusters (Vitis vinifera L.) different between conventional, organic, and biodynamic grapes? PLoS ONE 11:e0160852

Kembel SW, O'Connor TK, Arnold HK, Hubbell SP, Wright SJ, Green JL (2014) Rela- tionships between phyllosphere bacterial communities and plant functional traits in a neotropical forest. Proc Natl Acad Sci USA 111:13715-13720

Keppler F, Hamilton JT, Brass M, Röckmann T (2006) Methane emissions from terrestrial plants under aerobic conditions. Nature 439:187-191

Kernaghan G, Mayerhofer M, Griffin A (2017) Fungal endophytes of wild and hybrid Vitis leaves and their potential for vineyard biocontrol. Can J Microbiol 63(7):583-595 
Kharwar RN, Gond SK, Kumar A, Mishra AA (2010) A comparative study of endophytic and epiphytic fungal association with leaf of Eucalyptus citriodora Hook., and their antimicrobial activity. World J Microbiol Biotechnol 26:1941-1948

Kinkel LL (1997) Microbial population dynamics on leaves. Ann Rev Phytopathol 35:327-347

Kinkel LL, Wilson M, Lindow SE (2000) Plant species and plant incubation conditions influence variability in epiphytic bacterial population size. Microb Ecol 39:1-11

Knief C, Frances L, Vorholt JA (2010) Competitiveness of diverse Methylobacterium strains in the phyllosphere of Arabidopsis thaliana and identification of representative models, including $\mathrm{M}$. extorquens PA1. Microb Ecol 60(2):440-52. https://doi.org/10.1007/s00248-010-9725-3

Knief C, Delmotte N, Chaffron S, Stark M, Innerebner G, Wassmann R, von Mering C, Vorholt JA (2012) Metaproteogenomic analysis of microbial communities in the phyllosphere and rhizosphere of rice. ISME J 6:1378-1390

Kondo T, Yamamoto D, Yokota A, Suzuki A, Nagasawa H, Sakuda S (2000) Gordonan, an acidic polysaccharide with cell aggregation-inducing activity in insect BM-N4 cells, produced by Gordonia sp. Biosci Biotechnol Biochem 64:2388-2394

Konuklugil B (1995) The importance of Aryltetralin (Podophyllum) lignans and their distribution in the plant kingdom. Ankara Univ Eczacilik Fak Derg 24:109-125

Koskella B (2013) Phage-mediated selection on microbiota of a long-lived host. Curr Biol 23:12561260

Kotasthane AS, Agrawal T, Waris Zaidi N, Singh US (2017) Identification of siderophore producing and cynogenic fluorescent Pseudomonas and a simple confrontation assay to identify potential bio-control agent for collar rot of chickpea. 3 Biotech 7(2):137

Kour D, Rana KL, Yadav N, Yadav AN, Singh J, Rastegari AA, Saxena AK (2019) Agriculturally and industrially important fungi: current developments and potential biotechnological applications. In: Yadav AN, Singh S, Mishra S, Gupta A (eds) Recent advancement in white biotechnology through fungi, Volume 2: Perspective for value-added products and environments. Springer International Publishing, Cham, pp 1-64. https://doi.org/10.1007/978-3-030-14846-1_1

Krasnoff SB, Gupta S (1991) Identification and biosynthesis of efrapeptins in the fungus Tolypocladium geodes Gams (Deuteromycotina, Hyphomycetes). J Chem Ecol 17:1953-1960

Krasnoff SB, Gupta S, St Leger RJ, Renwick JA, Roberts DW (1991) Antifungal and insecticidal properties of efrapeptin metabolites of the fungus Tolypocladium niveum. J Invertebr Pathol 58:180-188

Krimm U, Abanda-Nkpwatt D, Schwab W, Schreiber L (2005) Epiphytic microorganisms on strawberry plants (Fragaria ananassa cv. Elsanta): identification of bacterial isolates and analysis of their interaction with leaf surfaces. FEMS Microbiol Ecol 53:483-492

Krishnamoorthy R, Kwon SW, Kumutha K, Senthilkumar M, Ahmed S, Sa T, Anandham R (2018) Diversity of culturable methylotrophic bacteria in diffrent genotypes of groundnut and their potential for plant growth promotion. 3 Biotech 8:275

Krol P, Iqielski R, Pollmann S, Kepczynska E (2015) Priming of seeds with methyl jasmonate induced resistance to hemi-biotroph Fusarium oxysporum f.sp. lycopersici in tomato via 12-oxophytodienoic acid, salicylic acid and flavonol accumulation. J Plant Physiol 179:122-132

Kumar S, Aharwal RP, Shukla H, Rajak RC, Sandhu SS (2014) Endophytic fungi: as a source of antimicrobials bioactive compounds. World J Pharm Pharm Sci 3:1179-1197

Kumar M, Kour D, Yadav AN, Saxena R, Rai PK, Jyoti A, Tomar RS (2019a) Biodiversity of methylotrophic microbial communities and their potential role in mitigation of abiotic stresses in plants. Biologia 74:287-308. https://doi.org/10.2478/s11756-019-00190-6

Kumar M, Saxena R, Rai PK, Tomar RS, Yadav N, Rana KL, Kour D, Yadav AN (2019b) Genetic diversity of methylotrophic yeast and their impact on environments. In: Yadav AN, Singh S, Mishra S, Gupta A (eds) Recent advancement in white biotechnology through fungi, Volume 3: Perspective for sustainable environments. Springer International Publishing, Cham, pp 53-71. https://doi.org/10.1007/978-3-030-25506-0_3 
Kwak MJ, Jeong H, Madhaiyan M, Lee Y, Sa TM, Oh TK, Kim JF (2014) Genome information of Methylobacterium oryzae, a plant-probiotic methylotroph methylotroph in the phyllosphere. PLoS ONE 9(9):e106704

Lambais MR, Crowley DE, Cury JC, Bull RC, Rodrigues RR (2006) Bacterial diversity in tree canopies of the Atlantic forest. Science 312:1917

Lane GA, Christensen MJ, Miles CO (2000) Coevolution of fungal endophytes with grasses: the significance of secondary metabolites. In: Bacon CW, White JFJ (eds) Microbial endophytes. Marcel Dekker, New York, pp 341-388

Lanubile A et al (2014) Functional genomic analysis of constitutive and inducible defense responses to Fusarium verticillioides infection in maize genotypes with contrasting ear rot resistance. BMC Genom 15:710

Leben C, Keitt GW (1954) Antibiotics and plant disease: effects of antibiotics in control of plant diseases. J Agric Food Chem 2:234-239

Lee MK, Chauhan PS, Yim WJ, Lee GJ, Kim YS, Park K, Sa TM (2011) Foliar colonization and growth promotion of red pepper (Capsicum annuиm L.) by Methylobacterium oryzae CBMB20. J Appl Biol Chem 54 (2):120-125

Leff JW, Del Tredici P, Friedman WE, Fierer N (2015) Spatial structuring of bacterial communities within individual Ginkgo biloba trees. Environ Microbiol 17:2352-2356

Legard DE, McQuilken MP, Whipps JM, Fenlon JS, Fermor TR, Thompson IP, Bailey MJ, Lynch JM (1994) Studies of seasonal changes in the microbial populations on the phyllosphere of spring wheat as a prelude to the release of a genetically modified microorganism. Agricult Ecosyst Environ 50:87-101

Lehmann S, Serrano ML, Haridon F, Tjamos SE, Metraux JP (2015) Reactive oxygen species and plant resistance to fungal pathogens. Phytochemistry 112:54-62

Lenhart K, Althoff F, Greule M, Keppler F (2015) Technical note: methionine, a precursor of methane in living plants. Biogeosciences 12:1907-1914

Leveau JH, Lindow SE (2001) Appetite of an epiphyte: quantitative monitoring of bacterial sugar consumption in the phyllosphere. Proc Natl Acad Sci USA 98:3446-3453

Leveau JHJ, Tech JJ (2011) Grapevine microbiomics: bacterial diversity on grape leaves and berries revealed by high-throughput sequence analysis of 16S rRNA amplicons. Acta Hort (ISHS) 905:31-42

Levy A, Salas Gonzalez I, Mittelviefhaus M, Clingenpeel S, Herrera Paredes S, Miao J et al (2018) Genomic features of bacterial adaptation to plants. Nat Genet 50:138-150

Lewer P, Chapin E, Graupner PR, Gilbert JR, Peacock C (2003) Tartrolone C: a novel insecticidal macrodiolide produced by Streptomyces sp. CP 1130. J Nat Prod 66:143-145

Lighthart B (1997) The ecology of bacteria in the alfresco atmosphere. FEMS Microbiol Ecol 23:263-274

Lindow SE, Brandl MT (2003) Microbiology of the phyllosphere. Appl Environ Microbiol 69:18751883

Liu C, Wang X, Zhao J, Liu Q, Wang W, Guan X et al (2013) Streptomyces harbinensis sp. nov., an endophytic, ikarugamycin-producing actinomycete isolated from soybean root [Glycine max (L.) Merr.]. Int J Syst Evol Microbiol 63:3579-3584

Liu Y, Jianwei Guo J, Li L, Asem MD, Zhang Y, Mohamad OA et al (2017) Endophytic bacteria associated with endangered plant Ferula sinkiangensis K. M. Shen in an arid land: diversity and plant growth-promoting traits. J Arid Land 9:432-445

Lizarazo-Medina PX, Gómez-Vásquez D (2015) Microbiota rizosférica de Espeletia spp. de los Páramos de Santa Inés y de Frontino-Urrao en Antioquia. Colombia. Acta Biol Colombiana 20:175-182

Loper JE, Lindow SE (1987) Lack of evidence for the in situ fluorescent pigment production by Pseudomonas syringae pv. syringae on bean leaf surfaces. Phytopathology 77:1449-1454

Lopez-Velasco G, Welbaum GE, Boyer RR, Mane SP, Ponder MA (2011) Changes in spinach phylloepiphytic bacteria communities following minimal processing and refrigerated storage described using pyrosequencing of 16S rRNA amplicons. J Appl Microbiol 110:1203-1214 
Luo S, Xu T, Chen L, Chen J, Rao C, Xiao X et al (2012) Endophyte-assisted promotion of biomass production and metal-uptake of energy crop sweet sorghum by plant-growth-promoting endophyte Bacillus sp. SLS18. Appl Microbiol Biotechnol 93:1745-1753

Lurdes Inácio M, Henriques J, Sousa E (2010) Mycobiota associated with Platypus cylindrus Fab. (Coleoptera: Platypodidae) on cork oak in Portugal. Integrated Protection in Oak Forests. IOBC/wprs Bull 57:87-95

Maignien L, DeForce EA, Chafee ME, Eren AM, Simmons SL (2014) Ecological succession and stochastic variation in the assembly of Arabidopsis thaliana phyllosphere communities. MBio 5:e00682-13

Manceau CR, Kasempour MN (2002) In Endophytic versus epiphytic colonization of plants: what comes first? In: Lindow SE, Hecht-Poinar EI, Elliott VJ (eds) Phyllosphere microbiology. APS Press, St Paul, USA, pp 115-123

Mansfield J, Genin S, Magori S, Citovsky V, Sriariyanum M, Ronald P et al (2012) Top 10 plant pathogenic bacteria in molecular plant pathology. Mol Plant Pathol 13:614-629

Mao DP, Zhou Q, Chen CY, Quan ZX (2012) Coverage evaluation of universal bacterial primers using the metagenomic datasets. BMC Microbiol 12:66

Martins F, Pereira JA, Bota P, Bento A, Baptista P (2016) Fungal endophyte communities in aboveand belowground olive tree organs and the effect of season and geographic location on their structures. Fungal Ecol 20:193-201

Masand M, Jose PA, Menghani E, Jebakumar SRD (2015) Continuing hunt for endophytic actinomycetes as a source of novel biologically active metabolites. World J Microbiol Biotechnol $31: 1863-1875$

Mase S (1984) Meiji Herbiace (MW-801, SF-1293) (common name: bialaphos) A new herbicide. Jpn Pestic Inf 45:27-30

Mason CJ, Couture JJ, Raffa KF (2014) Plant-associated bacteria degrade defense chemicals and reduce their adverse effects on an insect defoliator. Oecologia 175:901-910

Meena KK, Kumar M, Kalyuzhnaya MG, Yandigeri MS, Singh DP, Saxena AK et al (2012) Epiphytic pink-pigmented methylotrophic bacteria enhance germination and seedling growth of wheat (Triticum aestivum) by producing phytohormone. Antonie Van Leeuwenhoek 101:777-786

Meiners SJ, Phipps KK, Pendergast TH 4th, Canam T, Carson WP (2017) Soil microbial communities alter leaf chemistry and influence allelopathic potential among coexisting plant species. Oecologia 183:1155-1165

Meinhardt LW et al (2014) Genome and secretome analysis of the hemibiotrophic fungal pathogen, Moniliophthora roreri, which causes frosty pod rot disease of cacao: mechanisms of the biotrophic and necrotrophic phases. BMC Genom 15:164

Mejía LC, Rojas EI, Maynard Z, Bael SV, Arnold AE, Hebbar P et al (2008) Endophytic fungi as biocontrol agents of Theobroma cacao pathogens. Biol Control 46:4-14

Melotto M, Underwood W, He SY (2008) Role of stomata in plant innate immunity and foliar bacterial diseases. Ann Rev Phytopathol 46:101-122

Mendes R, Garbeva P, Raaijmakers JM (2013) The rhizosphere microbiome: significance of plant beneficial, plant pathogenic, and human pathogenic microorganisms. FEMS Microbiol Rev 37:634-663

Mercier J, Lindow SE (2000) Role of leaf surface sugars in coloni- zation of plants by bacterial epiphytes. Appl Environ Microbiol 66:369-374

Mertz FP, Yao RC (1990) Saccharopolyspora spinosa sp. nov. isolated from soil collected in a sugar mill rum still. Int J Syst Bacteriol 40:34-39

Methé BA, Li K, Talley SP, Gupta N, Frank B, Xu W, Gordon SG, Goodner B, Stapleton AE (2017) Functional genes that distinguish Maize phyllosphere metagenomes in drought and well-watered conditions. BioRxiv preprint online http://dx.doi.org/10.1101/104331

Michavila G, Adler C, De Gregorio PR, Lami MJ, Caram Di Santo MC, Zenoff AM, Cristobal RE, Vincent PA (2017) Pseudomonas protegens CS1 from the lemon phyllosphere as a candidate for citrus canker biocontrol agent. Plant Biol 19:608-617 
Mikiciński A, Sobiczewski P, Puławska J, Maciorowski R (2016) Control of fire blight (Erwini a amylovora) by a novel strain $49 \mathrm{M}$ of Pseudomonas graminis from the phyllosphere of apple (Malus spp.) Eur J Plant Pathol 145:265-276

Mikolasch A, Hammer E, Schauer F (2003) Synthesis of imidazol- 2-yl amino acids by using cells from alkane-oxidizing bacteria. Appl Environ Microbiol 69:1670-1679

Miller WG, Brandl MT, Quinones B, Lindow SE (2001) Biological sensor for sucrose availability: relative sensitivities of various reporter genes. Appl Environ Microbiol 67:1308-1317

Miller JD, Sumarah M, Adams G (2008) Effect of rugulosin producing endophyte is Picea galuca on Choristoneura fumifera. J Chem Ecol 34:362-368

Miranda M, Ralph SG, Mellway R, White R, Heath MC, Bohlmann J, Constabel CP (2007) The transcriptional response of hybrid poplar (Populas trichocarpa $\times$ P. deltoides) to infection by Melamspora medusa leaf rust involves induction of flavonoid pathway genes leading to accumulation of Proanthocyanidins. Mol Plant Microbe Interact 20:816-831

Mishima H, Ide J, Muramatsu S, Ono M (1983) Milbemycins, a new family of macrolide antibiotics. Structure determination of milbemycins D, E, F, G, H, J and K. J Antibiot 36:980-990

Miyamoto T, Kawahara M, Minamisawa K (2004) Novel endophytic nitrogen-fixing clostridia from the grass Miscanthus sinensis as revealed by terminal restriction fragment length polymorphism analysis. Appl Environ Microbiol 70:6580-6586

Mizuno M, Yurimoto H, Iguchi H, Tani A, Sakai Y (2013) Dominant Colonization and Inheritance of Methylobacterium sp. Strain OR01 on Perilla Plants. Biosci Biotechnol Biochem 77(7): 1533 1538

Mohammadi K (2012) Phosphorus solubilizing bacteria: occurrence, mechanisms mechanisms and their role in crop production. Resour Environ 2:80-85

Monaghan J, Zipfel C (2012) Plant pattern recognition receptor complexes at the plasma membrane. Curr Opin Plant Biol 15:349-357

Monier JM, Lindow SE (2004) Frequency, size, and localization of bacterial aggregates on bean leaf surfaces. Appl Environ Microbiol 70:346-355

Monier JM, Lindow SE (2005) Aggregates of resident bacteria facilitates survival of immigrant bacteria on leaf surfaces. Microbial Ecol 49:343-352

Morella NM, Gomez AL, Wang G, Leung MS, Koskella B (2018) The impact of bacteriophages on phyllosphere bacterial abundance and composition. Mol Ecol 27:2025-2038

Morris CE, Kinkel LL (2002) Fifty years of phylosphere microbiology: significant contributions to research in related fields. In: Lindow SE, Hecht-Poinar EI, Elliott V (eds) Phyllosphere microbiology. APS Press, St. Paul, Minn, pp 365-375

Morris CE, Monier J, Jacques M (1997) Methods for observing microbial biofilms directly on leaf surfaces and recovering them for isolation of culturable microorganisms. Appl Environ Microbiol 63:1570-1576

Morris CE, Monteil CL, Berge O (2013) The life history of Pseudomonas syringae: linking agriculture to earth system processes. Ann Rev Phytopathol 51:85-104

Mukhtar I, Khokhar I, Sobia M, Ali A (2010) Diversity of epiphytic and endophytic microorganisms in some dominant weeds. Pak J Weed Sci Res 16:287-297

Müller T, Ruppel S (2014) Progress in cultivation-independent phyllosphere microbiology. FEMS Microbiol Ecol 87:2-17

Müller H, Berg C, Landa BB, Auerbach A, Moissl-Eichinger C, Berg G (2015) Plant genotypespecific archaeal and bacterial endophytes but similar Bacillus antagonists colonize Mediterranean olive trees. Front Microbiol 6:138

Mwajita M, Murage H, Tani A, Kahangi EM (2013) Evaluation of rhizosphere, rhizoplane and phyllosphere bacteria and fungi isolated from rice in Kenya for plant growth promoters. Springerplus 2:606

Nadalig T, Ul F, Haque M, Roselli S, Schaller H, Bringel F, Vuilleumier S (2011) Detection and isolation of chloromethane-degrading bacteria from the Arabidopsis thaliana phyllosphere, and characterization of chloromethane utilization genes. FEMS Microbiol Ecol 77:438-448 
Nair DN, Padmavathy S (2014) Impact of endophytic microorganisms on plants, environment and humans. Sci World J. (https://doi.org/10.1155/2014/250693

Nalini MS, Prakash HS (2017) Diversity and bioprospecting of actinomycete endophytes from the medicinal plants. Lett Appl Microbiol 64:261-270

Nautiyal CS, Srivastava S, Chauhan PS, Seem K, Mishra A, Sopory SK (2013) Plant growthpromoting bacteria Bacillus amyloliquefaciens NBRISN13 modulates gene expression profile of leaf and rhizosphere community in rice during salt stress. Plant Physiol Biochem 66:1-9

Nehra V, Saharan BS, Choudhary M (2016) Evaluation of Brevibacillus brevis as a potential plant growth promoting rhizobacteria for cotton (Gossypium hirsutum) crop. SpringerPlus 5:948

Nevitt GA (2011) The neuroecology of dimethyl sulfide: a global-climate regulator turned marine infochemical. Integr Comp Biol 51:819-825

Newman MA, Sundelin T, Nielsen JT, Erbs G (2013) MAMP (microbe-associated molecular pattern) triggered immunity in plants. Front Plant Sci 4:139

Nguyen XH, Naing KW, Lee YS, Kim YH, Moon JH, Kim KY (2015) Antagonism of antifungal metabolites from Streptomyces griseus $\mathrm{H} 7602$ against Phytophthora capsici. J Basic Microbiol $55: 45-53$

Nimnoi P, Pongsilp N, Lumyong S (2010) Endophytic actinomycetes isolated from Aquilaria crassna Pierre ex. Lec and screening of plant growth-promoters production. World J Microbiol Biotechnol 26:193-203

Núñez-Trujillo G, Cabrera R, Burgos-Reyes RL, Silva ED, Giménez C, Cosoveanu A et al. (2012) Endophytic fungi from Vitis vinifera L. isolated in Canary Islands and Azores as potential biocontrol agents of Botrytis cinerea Pers.: Fr J Hortic For Biotechnol 16:1-6

Ohshiro M, Hossain MA, Nakamura I, Akamine H, Tamaki M, Bhowmik PC et al (2016) Effects of soil types and fertilizers on growth, yield, and quality of edible Amaranthus tricolor lines in Okinawa, Japan. Plant Prod Sci 19:61-72

Ondeyka JG, Helms GL, Hensens OD, Goetz MA, Zink DL, Tsipouras A, Shoop WL, Slayton L, Dombrowskii AW, Polishook JD, Ostlind DA, Tsou NN (1997) Nodulisporic acid A, a novel and potent insecticide from Nodulisporium sp. Isolation, structure determination and chemical transformation. J Am Chem Soc 119:8809-8816

Osono T (2006) Role of phyllosphere fungi of forest trees in the development of decomposer fungal communities and decomposition processes of leaf litter. Can J Microbiol 52:701-716

Osono T (2008) Endophytic and epiphytic phyllosphere fungi of Camellia japonica: seasonal and leaf age-dependent variations. Mycologia 100:387-391

Ottesen AR, González Peña A, White JR, Pettengill JB, Li C, Allard S et al (2013) Baseline survey of the anatomical microbial ecology of an important food plant: Solanum lycopersicum (tomato). BMC Microbiol 13:114

Park P, Tsuda H, Hayashi Y, Uneo T (1977) Effect of host specific toxin (AM toxin-I) produced by Alternaria mali, an apple pathogen, on ultrastructure of plasma membrane of cells in apple and japanese pear leaves. Can J Bot 55:2383-2393

Parthasarathi S, Sathya S, Bupesh G, Samy DR, Mohan MR, Selva GK et al (2012) Isolation and characterization of antimicrobial compound from marine Streptomyces hygroscopicus BDUS 49. World J Fish Mar Sci 4:268-277

Peiffer JA, Spor A, Koren O, Jin Z, Tringe SG, Dangl JL, Buckler ES, Ley RE (2013) Diversity and heritability of the maize rhizosphere microbiome under field conditions. Proc Natl Acad Sci 110:6548-6553

Porras-Alfaro A, Bayman P (2011) Hidden fungi, emergent properties: endophytes and microbiomes. Annu Rev Phytopathol 49:291-315

Prasad Sahu K, Kumar A (2015) Metagenomic analysis of rice phyllospheric bacterial communities in relation to blast disease. M.Sc., Thesis, Krishikosh Indian Agricultural Research Institute, New Delhi

Purahong W, Hyde KD (2011) Effects of fungal endophytes on grass and non-grass litter decomposition rates. Fungal Divers 47:1-7 
Pusey PL, Stockwell VO, Reardon CL, Smits THM, Duffy B (2011) Antibiosis activity of Pantoea agglomerans biocontrol strain E325 against Erwinia amylovora on apple flower stigmas. Phytopathology 101:1234-1241

Qin S, Xing K, Jiang JH, Xu LH, Li WJ (2011) Biodiversity, bioactive natural products and biotechnological potential of plant-associated endophytic actinobacteria. Appl Microbiol Biotechnol 89:457-473

Qin S, Bian GK, Zhang YJ, Xing K, Cao CL, Liu CH et al (2013) Modestobacter roseus sp. nov., an endophytic actinomycete isolated from the coastal halophyte Salicornia europaea Linn, and emended description of the genus Modestobacter. Int J Syst Evol Microbiol 63:2197-2202

Quan M, Liang J (2017) The influences of four types of soil on the growth, physiological and biochemical characteristics of Lycoris aurea (L' Her.) Herb Sci Rep 7. (https://doi.org/10.1038/ srep43284)

Radhakrishnan R, Hashem A, Abd_Allah EF (2017) Bacillus: a biological tool for crop improvement through bio-molecular changes in adverse environments. Front Physiol 8:667. https://doi.org/10. 3389/fphys.2017.00667

Ramírez Gómez M (2011) Importancia de los microorganismos y la edafofauna en los páramos. Colombia tiene Páramos 2011(1):42-57

Rana KL, Kour D, Sheikh I, Dhiman A, Yadav N, Yadav AN, Rastegari AA, Singh K, Saxena AK (2019a) Endophytic fungi: biodiversity, ecological significance and potential industrial applications. In: Yadav AN, Mishra S, Singh S, Gupta A (eds) Recent advancement in white biotechnology through fungi, vol 1. Diversity and Enzymes Perspectives. Springer, Switzerland, pp $1-62$

Rana KL, Kour D, Sheikh I, Yadav N, Yadav AN, Kumar V, Singh BP, Dhaliwal HS, Saxena AK (2019b) Biodiversity of endophytic fungi from diverse niches and their biotechnological applications. In: Singh BP (ed) Advances in endophytic fungal research: present status and future challenges. Springer International Publishing, Cham, pp 105-144. https://doi.org/10.1007/9783-030-03589-1_6

Rana KL, Kour D, Yadav AN (2019c) Endophytic microbiomes: biodiversity, ecological significance and biotechnological applications. Res J Biotechnol 14:142-162

Rasche F, Trondl R, Naglreiter C, Reichenauer TG, Sessitsch A (2006) Chilling and cultivar type affect the diversity of bacterial endophytes colonizing sweet pepper (Capsicum апиит L.). Can J Microbiol 52:1036-1045

Rastogi G, Sani RK (2011) Molecular techniques to assess microbial community structure, function, and dynamics in the environment. In: Ahmad I, Ahmad F, Pichtel J (eds) Microbes and Microbial Technology. Springer, New York, pp. 29-57

Rastogi G, Sbodio A, Tech JJ, Suslow TV, Coaker GL, Leveau JHJ (2012) Leaf microbiota in an agroecosystem: spatiotemporal variation in bacterial community composition on field-grown lettuce. ISME J 6:1812-1822

Rastogi G, Coaker GL, Leveau JHJ (2013) New insights into the structure and function of phyllosphere microbiota through high-throughput molecular approaches. FEMS Microbiol Lett 348:1-10. https://doi.org/10.1111/1574-6968.12225

Rawat SR, Mannisto MK, Bromberg Y, Haggblom MM (2012) Comparative genomic and physiological analysis provides insights into the role of Acidobacteria in organic carbon utilization in Arctic tundra soils. FEMS Microbiol Ecol 82:341-355

Redford AJ, Bowers RM, Knight R, Linhart Y, Fierer N (2010) The ecology of the phyllosphere: geographic and phylogenetic variability in the distribution of bacteria on tree leaves. Environ Microbiol 12:2885-2893

Reinhold-Hurek B, Hurek T (2011) Living inside plants: bacterial endophytes. Curr Opin Plant Biol 14:435-443

Reinhold-Hurek B, Bunger W, Burbano CS, Sabale M, Hurek T (2015) Roots shaping their microbiome: global hotspots for microbial activity. Ann Rev Phytopathol 53:403

Reino JL, Guerrero RF, Hernández-Galán R, Collado IG (2008) Secondary metabolites from species of the biocontrol agent Trichoderma. Phytochem Rev 7:89-123 
Remus-Emsermann MNP, Schlechter RO (2018) Phyllosphere microbiology: at the interface between microbial individuals and the plant host. New Phytol 218:1327-1333

Remus-Emsermann MNP, de Oliveira S, Schreiber L, Leveau JHJ (2011) Quantification of lateral heterogeneity in carbohydrate permeability of isolated plant leaf cuticles. Front Microbiol 2:197

Remus-Emsermann MNP, Tecon R, Kowalchuk GA, Leveau JHJ (2012) Variation in local carrying capacity and the individual fate of bacterial colonizers in the phyllosphere. ISME Journal 6:756765

Remus-Emsermann MNP, Kim EB, Marco ML, Tecon R, Draft Leveau JHJ (2013) Genome sequence of the phyllosphere model bacterium Pantoea agglomerans 299R. Genome Announc. https://doi.org/10.1128/genomea.00036-13

Ren G, Zhang H, Lin X, Zhu J, Jia Z (2014) Response of phyllosphere bacterial communities to elevated $\mathrm{CO}_{2}$ during rice growing season. Appl Microbiol Biotechnol 98:9459-9471

Rico L, Ogaya R, Terradas J, Peñuelas J (2014) Community structures of $\mathrm{N}_{2}$-fixing bacteria associated with the phyllosphere of a Holm oak forest and their response to drought. Plant Biol 16:586-593

Ripa FA, Cao WD, Tong S, Sun JG (2019) Assessment of plant growth promoting and abiotic stress tolerance properties of wheat endophytic fungi. BioMed Res Int 6105865:12. (https://doi.org/10. $1155 / 2019 / 6105865$

Rivera-Vargas LI, Lugo-Noel Y, McGovern RJ, Seijo T, Davis MJ (2006) Occurrence and distribution of Colletotrichum spp. on Mango (Mangifera indica L.) in Puerto Rico and Florida, USA. Plant Pathol J 5:191-198

Rodrigues KF (1994) The foliar fungal endophytes of the Amazonian palm Euterpe oleracea. Mycologia 86(3):376-385

Rodriguez RJ, White JF, Arnold AE, Redman RS (2009) Fungal endophytes: diversity diversity and functional roles. New Phytol 182:314-330

Rodríguez-Escobar C, Mitter B, Barret M, Sessitsch A, Compant S (2018) Commentary: seed bacterial inhabitants and their routes of colonization. Plant Plant Soil 422:129-134

Rosa LH, Tabanca N, Techen N, Pan Z, Wedge DE, Moraes RM (2012) Antifungal activity of extracts from endophytic fungi associated with Smallanthus maintained in vitro as autotrophic cultures and as pot plants in the greenhouse. Can J Microbiol 58(10):1202-1221

Roselli S, Nadalig T, Vuilleumier S, Bringel F (2013) The $380 \mathrm{~kb}$ pCMU01 plasmid encodes chloromethane utilization genes and redundant genes for vitamin B12- and tetrahydrofolatedependent chloromethane metabolism in Methylobacterium extorquens CM4: a proteomic and bioinformatics study. PLoS ONE 8:e56598

Rudd JJ et al (2015) Transcriptome and metabolite profiling the infection cycle of Zymoseptoria tritici on wheat (Triticum aestivum) reveals a biphasic interaction with plant immunity involving differential pathogen chromosomal contributions, and a variation on the hemibiotrophic lifestyle definition. Plant Physiol 167:1158-1185

Ruiz-Pérez CA, Restrepo S, Zambrano MM (2016) Microbial and functional diversity within the phyllosphere of Espeletia species in an Andean high-mountain ecosystem. Appl Environ Microbiol 82:1807-1817

Sadler C, Schroll B, Zeisler V, Waßmann F, Franke R, Schreiber L (2016) Wax and cutin mutants of Arabidopsis: quantitative characterization of the cuticular transport barrier in relation to chemical composition. Biochim Biophys Acta 1861:1336-1344

Salam N, Khieu TN, Liu MJ, Vu TT, Ky SC, Quach NT et al (2017) Endophytic actinobacteria associated with Dracaena cochinchinensis Lour: isolation, diversity, and their cytotoxic activities. Biomed Res Int 2017:1-11

Salazar-Cerezo S, Martinez-Montiel N, del Carmen C-LM, Martinez-Contreras RD (2018) Fungal diversity and community composition of culturable fungi in Stanhopea trigrina Cast Gibberellin producers. Front Microbiol 9:612

Saleem M, Meckes N, Pervaiz ZH, Traw MB (2017) Microbial interactions in the phyllosphere increase plant performance under Herbivore biotic stress. Front Microbiol 8:41 
San Roman M, Wagner A (2018) An enormous potential for niche construction through bacterial cross-feeding in a homogeneous environment. PLoS Comput Biol 14(7):e1006340

Santhanam R, Groten K, Meldau DG, Baldwin IT (2014) Analysis of plant-bacteria interactions in their native habitat: bacterial communities associated with wild tobacco are independent of endogenous jasmonic acid levels and developmental stages. PLoS ONE 9:e94710

Šantl-Temkiv T, Finster K, Dittmar T, Hansen BM, Thyrhaug R, Nielsen NW et al (2013) Hailstones: a window into the microbial and chemical inventory of a storm cloud. PLoS ONE 8:e53550

Santoyo G, Moreno-Hagelsieb G, del Orozco-Mosqueda MC, Glick BR (2016) Plant growthpromoting bacterial endophytes. Microbiol Res 183:92-99

Sapp M, Ploch S, Fiore-Donno AM, Bonkowski M, Ros LE (2018) Protists are an integral part of the Arabidopsis thaliana microbiome. Environ Microbiol 20:30-43

Sawinski K, Mersmann S, Robatzek S, Böhmer M (2013) Guarding the green: pathways to stomatal immunity. Mol Plant Microbe Interact 26:626-632

Saxena S (2014) Microbial metabolites for development of ecofriendly agrochemicals. Allelopath J 33(1):1-24

Scavino AF, Pedraza RO (2013) The role of siderophores in plant growth-promoting bacteria. In: Maheshwari DK, Saraf M, Aeron A (eds) Bacteria in agrobiology: crop productivity. Springer, Berlin, pp 265-285. https://doi.org/10.1007/978-3-642-37241-4-11

Schäfer H, Myronova N, Boden R (2010) Microbial degradation of dimethylsulphide and related $\mathrm{C}_{1}$-sulphur compounds: organisms and pathways controlling fluxes of sulphur in the biosphere. J Exp Bot 61:315-334

Schlechter RO, Mitja MM, Remus-Emsermann NP (2019) Driving factors of epiphytic bacterial communities: A review. Journal of Advanced Research 19:57-65

Schönherr J (2006) Characterization of aqueous pores in plant cuticles and permeation of ionic solutes. J Exp Bot 57:2471-2491

Schreiber L (2005) Polar paths of diffusion across plant cuticles: new evidence for an old hypothesis. Ann Bot 95:1069-1073

Selvakumar G, Kundu S, Joshi P, Nazim S, Gupta AD, Gupta HS (2010) Growth promotion of wheat seedlings by Exiguobacterium acetylicum 1P (MTCC 8707) a cold tolerant bacterial strain from the Uttarakhand Himalayas. Indian J Microbiol 50:50-56

Sessitsch A, Hackl E, Wenzl P, Kilian A, Kostic T, Stralis-Pavese N, Sandjong BT et al (2006) Diagnostic microbial microarrays in soil ecology. New Phytol 171:719-736

Setati ME, Jacobson D, Andong UC, Bauer FF (2012) The vineyard yeast microbiome, a mixed model microbial map. PLoS ONE 7:e52609

Shade A, McManus PS, Handelsman J (2013) Unexpected diversity during community succession in the apple flower microbiome. MBio 4:e00602-12

Shahzad R, Waqas M, Khan AL, Asaf S, Khan MA, Kang SM et al (2016) Seed-borne endophytic Bacillus amyloliquefaciens RWL-1 produces gibberellins and regulates endogenous phytohormones of Oryza sativa. Plant Physiol Biochem 106:236-243

Sharma PS, D'Souza F, Kutner W (2012) Molecular imprinting for selective chemical sensing of hazardous compounds and drugs of abuse. Trac Trend Anal Chem 34:59-77

Shen Y, Liu C, Wang X, Zhao J, Jia F, Zhang Y (2013) Actinoplanes hulinensis sp nov., a novel actinomycete isolated from soybean root (Glycine max (L.) Merr). Antonie Van Leeuwenhoek 103:293-298

Shepherd RW, Bass WT, Houtz RL, Wagner GJ (2005) Phylloplanins of tobacco are defensive proteins deployed on aerial surfaces by short glandular trichomes. Plant Cell 17:1851-1886

Shin S, Lv J, Fazio G, Mazzola M, Zhu Y (2014) Transcriptional regulation of ethylene and jasmonate mediated defense response in apple (Malus domestica) root during Pythium ultimum infection. Hort Res 1:14053

Shiraishi K, Oku M, Kawaguchi K, Uchida D, Yurimoto H, Sakai Y (2015) Yeast nitrogen utilization in the phyllosphere during plant lifespan under regulation of autophagy. Sci Rep 5:09719 
Shrestha BK, Karki HS, Groth DE, Jungkhun N, Ham JH (2016) Biological control activities of rice-associated Bacillus sp. Strains against sheath blight and bacterial panicle blight of rice. PLoS One 11:e0146764

Shukla ST, Habbu PV, Kulkarni VH, Jagadish KS, Pandey AR, Sutariya VN (2014) Endophytic microbes: a novel source for biologically/pharmacologically active secondary metabolites. Asian J Pharmacol Toxicol 2:1-16

Singh R, Dubey AK (2015) Endophytic actinomycetes as emerging source for therapeutic compounds. Indo Global J Pharm Sci 5:106-116

Singh BK, Nazaries L, Munro S, Anderson IC, Campbell CD (2006) Use of multiplex terminal restriction fragment length polymorphism for rapid and simultaneous analysis of different components of the soil microbial community. Appl Environ Microbiol 72:7278-7285

Singh R, Ashok K, Dubey (2018) Diversity and applications of endophytic actinobacteria of plants in special and other ecological niches 9:1767

Snelders NC, Kettles GJ, Rudd JJ, Thomma BPHJ (2018) Plant pathogen effector proteins as manipulators of host microbiomes? Mol Plant Pathol 19:257-259

Soliman SSM, Raizada MN (2018) Darkness: a crucial factor in fungal taxol production. Front Microbiol 9:353

Specian V, Sarragiotto MH, Pamphile JA, Clemente E (2012) Chemical characterization of bioactive compounds from the endophytic fungus Diaporthe helianthi isolated from Luehea divaricata. Braz J Microbiol 43:1174-1182

Sreekanth D, Kristin IM, Brett AN (2017) Endophytic fungi from Cathranthus roseus: a potential resource for the discovery of antimicrobial polyketides. Nat Prod Chem Res 5:256

Staley C, Dunny GM, Sadowsky MJ (2014) Environmental and animal-associated enterococci. Adv Appl Microbiol 87:147-186

Steven B, Huntley RB, Zeng Q (2018) The influence of flower anatomy and apple cultivar cultivar on the apple flower phytobiome. Phytobiomes J 2:171-179

Stierle A, Cardellina H, Strobel G (1990) Maculosin, a host-specific phytotoxin from Alternaria alternata on spotted knapweed. Am Chem Soc Symp Ser 439:53-62

Strasser H, Vey A, Butt TM (2000) Are there any risks in using entomopathogenic fungi for pest control with particular reference to bioactive metabolites of Metarrhizium, Tolypocladium and Beauveria sp.? Biocontrol Sci Tech 10:717-735

Strobel GA, Daisy B (2003) Bioprospecting for microbial endophytes and their natural products. Microbiol Mol Biol Rev 67:491-502

Stubbendieck RM, Vargas-Bautista C, Straight PD (2016) Bacterial communities: interactions to scale. Front Microbiol 7:1234

Suda W, Nagasaki A, Shishido M (2009) Powdery mildew-infection changes bacterial community composition in the phyllosphere. Microbes Environ 24:217-223

Sun Y et al (2010) The role of wheat Jasmonic acid and ethylene pathways in response to Fusarium graminearum infection. Plant Growth Regul 80:69-77

Suslow TV (2002) Production practices affecting the potential for persistent contamination of plants by microbial foodborne pathogens. In: Lindow SE, Hecht-Poinar EI, Elliott VJ (eds) Phyllosphere microbiology. APS Press, St Paul, USA, pp 241-256

Sy A, Timmers AC, Knief C, Vorholt JA (2005) Methylotrophic metabolism is advantageous for Methylobacterium extorquens during colonization of Medicago truncatula under competitive conditions. Appl Environ Microbiol 71:7245-7252

Sziderics AH, Rasche F, Trognitz F, Sessitsch A, Wilhelm E (2007) Bacterial endophytes contribute to abiotic stress adaptation in pepper plants (Capsicum annuиm L.). Can J Microbiol 53:11951202

Tachibana K (2003) Bialaphos, a natural herbicide. Meiji Seika Kenkyo Nenpo 42:44-57

Tecon R, Leveau JHJ (2016) Symplasmata are a clonal, conditional, and reversible type of bacterial multicellularity. Sci Rep 6:31914

Tecon R, Ebrahimi A, Kleyer H, Erev Levi S, Or D (2018) Cell-to-cell bacterial interactions promoted by drier conditions on soil surfaces. PNAS 115(39):9791-9796 
Thamchaipenet A, Indananda C, Bunyoo C, Duangmal K, Matsumoto A, Takahashi Y (2010) Actinoallomurus acaciae sp. nov., an endophytic actinomycete isolated from Acacia auriculiformis, A Cunn. ex Benth. Int J Syst Evol Microbiol 60:554-559

Thapa S, Ranjan K, Ramakrishnan B, Velmourougane K, Prasanna R (2018) Influence of fertilizers and rice cultivation methods on the abundance and diversity of phyllosphere microbiome. J Basic Microbiol 58:172-186

Thompson IP, Bailey MJ, Fenlon JS, Fermor TR, Lilley AK, Lynch JM, McCormack PJ, McQuilken MP et al (1993) Quantitative and qualitative seasonal changes in the microbial community from the phyllosphere of sugar beet (Beta vulgaris). Plant Soil 150:177-191

Trabelsi D, Mhamdi R (2013) Microbial inoculants and their impact on soil microbial communities: a review. Biomed Res Int

Trdá L, Boutrot F, Claverie J, Brulé D, Dorey S, Poinssot B (2015) Perception of pathogenic or beneficial bacteria and their evasion of host immunity: pattern recognition receptors in the frontline. Front Plant Sci 6:219

Trouvelot S, Héloir MC, Poinssot B, Gauthier A, Paris F, Guillier C et al (2014) Carbohydrates in plant immunity and plant protection: roles and potential application as foliar sprays. Front Plant Sci 5:592

Twizeyimana M, Förster H, McDonald V, Wang DH, Adaskaveg JE, Eskalen A (2013) Identification and pathogenicity of fungal pathogens associated with stem-end rot of avocado in California. Plant Dis $97(12): 1580-1584$

Umezawa H, Okami Y, Hashimoto T, Suhara Y, Otake N (1965) A new antibiotic kasugamycin. J Antibiot Ser A 18:101-103

Uneo T (1990) Secondary metabolites related to host selection by plant pathogenic fungi. Pure Appl Chem 62:1347-1352

Uppalapati SR et al (2009) Global gene expression profiling during Medicago truncatulaPhymatotrichopsis omnivora interaction reveals a role for Jasmonic acid, Ethylene and the Flavonoid pathway in disease development. Mol Plant Microbe Interac 22:7-17

Uroz S, Buee M, Deveau A, Mieszkin S, Martin F (2016) Ecology of the forest microbiome: highlights of temperate and boreal ecosystems. Soil Biol Biochem 103:471-488

Vacher C, Hampe A, Porte AJ, Sauer U, Compant S, Morris CE (2016) The phyllosphere: microbial jungle at the plant-climate interface. Ann Rev Ecol Evol Syst 47:1-24

Vaïtilingom M, Deguillaume L, Vinatier V, Sancelme M, Amato P, Chaumerliac N et al (2013) Potential impact of microbial activity on the oxidant capacity and organic carbon budget in clouds. Proc Natl Acad Sci USA 110:559-564

Van der Wal A, Leveau JHJ (2011) Modelling sugar diffusion across plant leaf cuticles: the effect of free water on substrate availability to phyllosphere bacteria. Environ Microbiol 13:792-797

Van der Wal A, Tecon R, Kreft J-U, Mooij WM, Leveau JHJ (2013) Explaining bacterial dispersion on leaf surfaces with an individual-based model (PHYLLOSIM). PLoS ONE 8(10):e75633

Van Kan JAL, Shaw MW, Grant-Downton RT (2014) Botrytis species: relentless necrotrophic thugs or endophytes gone rogue? Mol Plant Pathol 15:957-961

Vargas WA et al (2012) Plant defense mechanisms are activated during biotrophic and necrotrophic development of Colletotricum graminicola in maize. Plant Physiol 158:1342-1358

Venkatachalam S, Ranjan K, Prasanna R, Ramakrishnan B, Thapa S, Kanchan A (2016) Diversity and functional traits of culturable microbiome members, including cyanobactera in the rice phyllosphere. Plant Biol 18:627-637

Verginer M, Leitner E, Berg G (2010) Production of volatile metabolites by grape associated microorganisms. J Agric Food Chem 58:8344-8350

Verma P, Yadav AN, Kazy SK, Saxena AK, Suman A (2013) Elucidating the diversity and plant growth promoting attributes of wheat (Triticum aestivum) associated acidotolerant bacteria from southern hills zone of India. Natl J Life Sci 10:219-227

Verma P, Yadav AN, Khannam KS, Panjiar N, Kumar S, Saxena AK, Suman A (2015) Assessment of genetic diversity and plant growth promoting attributes of psychrotolerant bacteria allied with wheat (Triticum aestivum) from the northern hills zone of India. Ann Microbiol 65:1885-1899 
Verma P, Yadav AN, Khannam KS, Kumar S, Saxena AK, Suman A (2016a) Molecular diversity and multifarious plant growth promoting attributes of Bacilli associated with wheat (Triticum aestivum L.) rhizosphere from six diverse agro-ecological zones of India. J Basic Microbiol $56: 44-58$

Verma P, Yadav AN, Khannam KS, Mishra S, Kumar S, Saxena AK, Suman A (2016b) Appraisal of diversity and functional attributes of thermotolerant wheat associated bacteria from the peninsular zone of India. Saudi J Biol Sci. https://doi.org/10.1016/j.sjbs.2016.01.042

Verma P, Yadav AN, Kumar V, Singh DP, Saxena AK (2017) Beneficial plant-microbes interactions: biodiversity of microbes from diverse extreme environments and its impact for crop improvement. In: Singh DP, Singh HB, Prabha R (eds) Plant-microbe interactions in agro-ecological perspectives, vol 2. Microbial Interactions and Agro-Ecological Impacts. Springer, Singapore, pp 543-580. https://doi.org/10.1007/978-981-10-6593-4_22

Videira SIR, Groenewald JZ, Verkley GJM, Braun U, Crous PW (2015) The rise of Ramularia from the Mycosphaerella labyrinth. Fungal Biol 119:823-843

Vokou D, Vareli K, Zarali E, Karamanoli K, Constantinidou HI, Monokrousos N, Halley JM, Sainis I (2012) Exploring biodiversity in the bacterial community of the Mediterranean phyllosphere and its relationship with airborne bacteria. Microb Ecol 64:714-724

Vorholt JA (2012) Microbial life in the phyllosphere. Nat Rev 10:828-840

Vořišková J, Baldrian P (2013) Fungal community on decomposing leaf litter undergoes rapid successional changes. ISME J 7:477-486

Walker AP, McCormack ML, Messier J, Myers-Smith IH, Wullschleger SD (2017) Trait covariance: the functional warp of plant diversity? New Phytol 216:976-980

Walsh UF, Morrissey JP, O'Gara F (2001) Pseudomonas for biocontrol of phytopathogens: from functional genomics to commercial exploitation. Curr Opin Biotechnol 12:289-295

Wang M, Ma Q (2011) Antagonistic Actinomycete XN-1 from phyllosphere microorganisms of cucumber to control corynespora cassiicola. Cucurbit Genet Coop Rep 33-34:17-21

Wang X, Radwan MM, Taráwneh AH, Gao J, Wedge DE, Rosa LH et al (2013a) Antifungal activity against plant pathogens of metabolites from the endophytic fungus Cladosporium cladosporioides. J Agric Food Chem 61:4551-4555

Wang X, Zhao J, Liu C, Wang J, Shen Y, Jia F et al (2013b) Nonomuraea solani sp. nov., an actinomycete isolated from eggplant root (Solanum melongena L.). Int J Syst Evol Microbiol 63:2418-2423

Wang J, Hu M, Wang J, Qi J, Han Z, Wang G, Qi Y, Wang HW, Zhou JM, Chai J (2019) Reconstitution and structure of a plant NLR resistosome conferring immunity. Science 364(6435)

Wensing A, Braun SD, Buttner P, Expert D, Volksch B, Ullrich MS et al (2010) Impact of siderophore production by Pseudomonas syringae pv. syringae $22 \mathrm{~d} / 93$ on epiphytic fitness and biocontrol activity against $P$ seudomonas syringae pv. glycinea 1a/96. Appl Environ Microbiol 76:2704-2711

Whipps JM, Hand P, Pink D, Bending GD (2008) Phyllosphere microbiology with special reference to diversity and plant genotype. J Appl Microbiol 105:1744-1755

Wicklow DT, Roth S, Deyrup ST, Gloer JB (2005) A protective endophyte of maize: Acremonium zeae antibiotics inhibitory to Aspergillus flavus and Fusarium verticillioides. Mycol Res 109:610 618

Williams TR, Moyne A-L, Harris LJ, Marco ML (2013) Season, irrigation, leaf age, and Escherichia coli inoculation influence the bacterial diversity in the lettuce phyllosphere. PLoS ONE 8:e68642

Win PM, Matsumura E, Fukuda K (2019) Diversity of tea endophytic fungi: cultivar- and tissue preferences. Appl Ecol Environ Res 16(1):677-695

Worapong J, Strobel GA, Ford EJ, Li JY, Baird G, Hess WM (2001) Muscodor albus anam. nov., an endophyte from Cinnamomum zeylanicum. Mycotaxon 79:67-79

Wright SAI, ZumoffCH, Schneider L, Beer SV (2001) Pantoea agglomerans Strain EH318 produces two antibiotics that inhibit Erwinia amylovora in vitro. Appl Environ Microbiol 67:284-292

Wu L, Chen H, Curtis C, Fu ZQ (2014) Go in for the kill: How plants deploy effector-triggered immunity to combat pathogens. Virulence 5(7):710-721 
Wulff EG, Van Vuurde JWL, Hockenhull J (2003) The ability of the biological control agent Bacillus subtilis, strain $\mathrm{BB}$, to colonise vegetable brassicas endophytically following seed inoculation. Plant Soil 255:463-474

Xie QY, Wang C, Wang R, Qu Z, Lin HP, Goodfellow M et al (2011) Jishengella endophytica gen. nov., sp. nov., a new member of the family Micromonosporaceae. Int J Syst Evol Microbiol 61:1153-1159

Yadav AN (2017) Agriculturally important microbiomes: biodiversity and multifarious PGP attributes for amelioration of diverse abiotic stresses in crops for sustainable agriculture. Biomed J Sci Tech Res 1:1-4

Yadav AN, Yadav N (2018) Stress-Adaptive Microbes for Plant Growth Promotion and Alleviation of Drought Stress in Plants. Acta Sci Agric 2:85-88

Yadav N, Yadav AN (2019) Actinobacteria for sustainable agriculture. Journal of Applied Biotechnology and Bioengineering 6:38-41

Yadav AN, Sachan SG, Verma P, Saxena AK (2015a) Prospecting cold deserts of north western Himalayas for microbial diversity and plant growth promoting attributes. J Biosci Bioeng 119:683-693

Yadav AN, Sachan SG, Verma P, Tyagi SP, Kaushik R, Saxena AK (2015b) Culturable diversity and functional annotation of psychrotrophic bacteria from cold desert of Leh Ladakh (India). World J Microbiol Biotechnol 31:95-108

Yadav AN, Kumar V, Prasad R, Saxena AK, Dhaliwal HS (2018a) Microbiome in Crops: Diversity, distribution and potential role in crops improvements. In: Prasad R, Gill SS, Tuteja N (eds) Crop Improvement through Microbial Biotechnology. Elsevier, USA, pp 305-332

Yadav AN, Verma P, Kumar S, Kumar V, Kumar M, Singh BP, Saxena AK, Dhaliwal HS (2018b) Actinobacteria from Rhizosphere: Molecular Diversity, Distributions and Potential Biotechnological Applications. In: Singh B, Gupta V, Passari A (eds) New and Future Developments in Microbial Biotechnology and Bioengineering. USA, pp 13-41. https://doi.org/10.1016/b978-0444-63994-3.00002-3

Yadav AN, Verma P, Kumar V, Sangwan P, Mishra S, Panjiar N, Gupta VK, Saxena AK (2018c) Biodiversity of the Genus Penicillium in Different Habitats. In: Gupta VK, Rodriguez-Couto S (eds) New and Future Developments in Microbial Biotechnology and Bioengineering, Penicillium System Properties and Applications. Elsevier, Amsterdam, pp 3-18. https://doi.org/10.1016/ b978-0-444-63501-3.00001-6

Yadav AN, Kour D, Sharma S, Sachan SG, Singh B, Chauhan VS, Sayyed RZ, Kaushik R, Saxena AK (2019a) Psychrotrophic Microbes: Biodiversity, Mechanisms of Adaptation, and Biotechnological Implications in Alleviation of Cold Stress in Plants. In: Sayyed RZ, Arora NK, Reddy MS (eds) Plant Growth Promoting Rhizobacteria for Sustainable Stress Management: Volume 1: Rhizobacteria in Abiotic Stress Management. Springer Singapore, Singapore, pp 219-253. https://doi.org/10.1007/978-981-13-6536-2_12

Yadav AN, Mishra S, Singh S, Gupta A (2019b) Recent Advancement in White Biotechnology Through Fungi Volume 1: Diversity and Enzymes Perspectives. Springer International Publishing, Cham

Yadav AN, Singh S, Mishra S, Gupta A (2019c) Recent advancement in white biotechnology through fungi. Volume 2: Perspective for Value-Added Products and Environments. Springer International Publishing, Cham

Yadav AN, Singh S, Mishra S, Gupta A (2019d) Recent Advancement in White Biotechnology Through Fungi. Volume 3: Perspective for Sustainable Environments. Springer International Publishing, Cham

Yang CH, Crowley DE, Borneman J, Keen NT (2001) Microbial phyllosphere populations are more complex than previously realized. PNAS 98:3889-3894

Yang F, Li W, Jorgensen HJL (2013) Transcriptional reprogramming of Wheat and the hemibiotrophic pathogen Septoria tritici during two phases of the compatible interaction. PLoS ONE 8(11):e81606 
Yao H, Sun X, He C, Maitra P, Li XC, Guo LD (2019) Phyllosphere epiphytic and endophytic fungal community and network structures differ in a tropical mangrove ecosystem. Microbiome $7: 57$

Yu X, Lund SP, Scott RA, Greenwald JW, Records AH, Nettleton D, Lindow SE, Gross DC, Beattie GA (2013) Transcriptional responses of Pseudomonas syringae to growth in epiphytic versus apoplastic leaf sites. P Natl Acad Sci USA 29:E425-E434

Zak JC (2002) Implications of a leaf surface habitat for fungal community structure and function. In: Lindow SE, Hecht-Poinar EI, Elliott VJ (eds) Phyllosphere Microbiology. APS Press, St Paul, USA, pp 299-315

Zarraonaindia I, Owens SM, Weisenhorn P, West K, Hampton-Marcell J, Lax S, Bokulich NA, Mills DA, Martin G, Taghavi S et al (2015) The soil microbiome influences grapevine-associated microbiota. MBio 6:e2527-e02514

Zeilinger S, Gupta VK, Dahms TES, Silva RN, Singh HB, Upadhyay RS, Vieira Gomes E, Kin-Ming Tsui C, Chandra Nayak S (2016) Friends or foes? Emerging insights from fungal interactions with plants. FEMS Microbiol Rev. Mar 40(2): 182-207

Zeiller M, Rothballer M, Iwobi AN, Böhnel H, Gessler F, Hartmann A et al (2015) Systemic colonization of clover (Trifolium repens) by clostridium botulinum strain 2301. Front. Microbiol. 6:1207. https://doi.org/10.3389/fmicb.2015.01207

Zhang P, Zhou PP, Yu LJ (2009) An endophytic taxol-producing fungus from Taxus media, Cladosporium cladosporioides MD2. Curr Microbiol 59:227-232

Zhang YG, Wang HF, Alkhalifah DHM, Xiao M, Zhou XK, Liu YH et al (2018) Glycomyces anabasis sp. nov., a novel endophytic actinobacterium isolated from roots of Anabasis aphylla L. Int J Syst Evol Microbiol 68:1285-1290

Zhu WY, Zhang JL, Qin YL, Xiong ZJ, Zhang DF, Klenk HP et al (2013) Blastococcus endophyticus sp. nov., an actinobacterium isolated from Camptotheca acuminata. Int J Syst Evol Microbiol 63:3269-3273

Zonno MC, Vurro M, Luceretti S, Andolfi A, Perrone C, Evidente A (2008) Phyllostictine A, potential herbicide produced by Phyllosticta cirsii: in vitro production and toxicity. Plant Sci 175:818-828

Zuluaga AP, Vega-Arreguín JC, Fei Z, Ponnala L, Lee SJ, Matas AJ, Patev S, Fry WE, Rose JK (2016) Transcriptional dynamics of Phytophthora infestans during sequential stages of hemibiotrophic infection of tomato. Mol Plant Pathol 17:42-54 